\title{
UC-NRLF
}

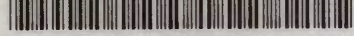

B $3336 \quad 342$

A KEY

TO THE

BIRDS OF AUSTRALIA AND

TASMA NIA

WITH THEIR

GEOGRAPHICAL DISTRIBUTION

IN AUSTRALIA

BY ROBERT HALL

arelbourne

MELVILLE, MULLEN AND SLADE, COLLINS STREET

Sontort

DULAU AND CO, 37 SOHO SQUARE.

[COPYRTINT] 


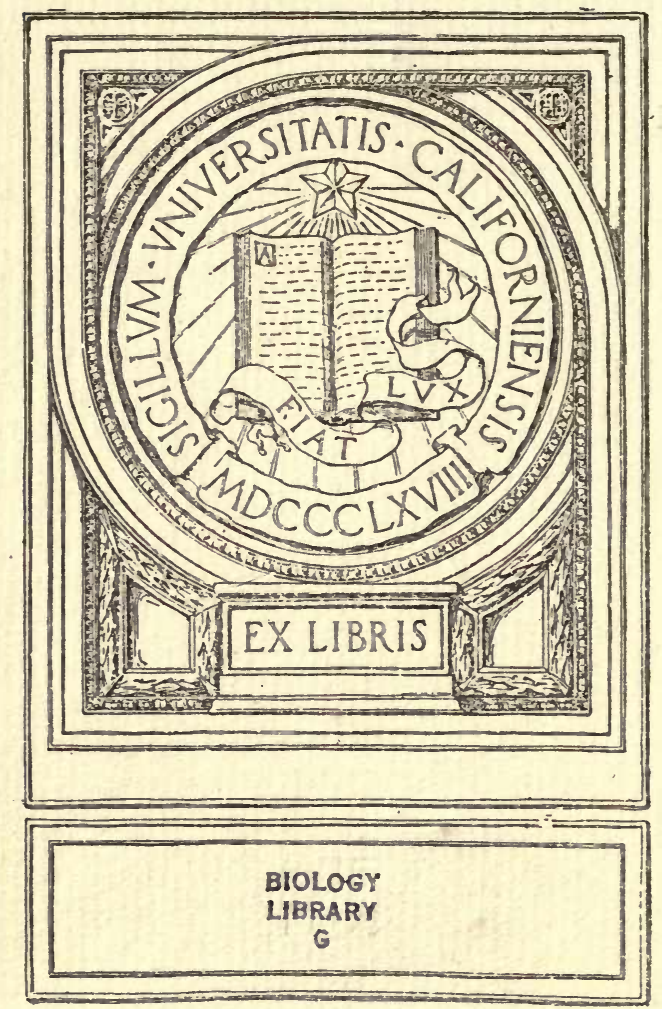


Trom the Auchoos.

meer.vii.

$$
5: 2=00 \text {, }
$$


1 
A KEY

TO THE

BIRDS OF AUSTRALIA AND TASMANIA 


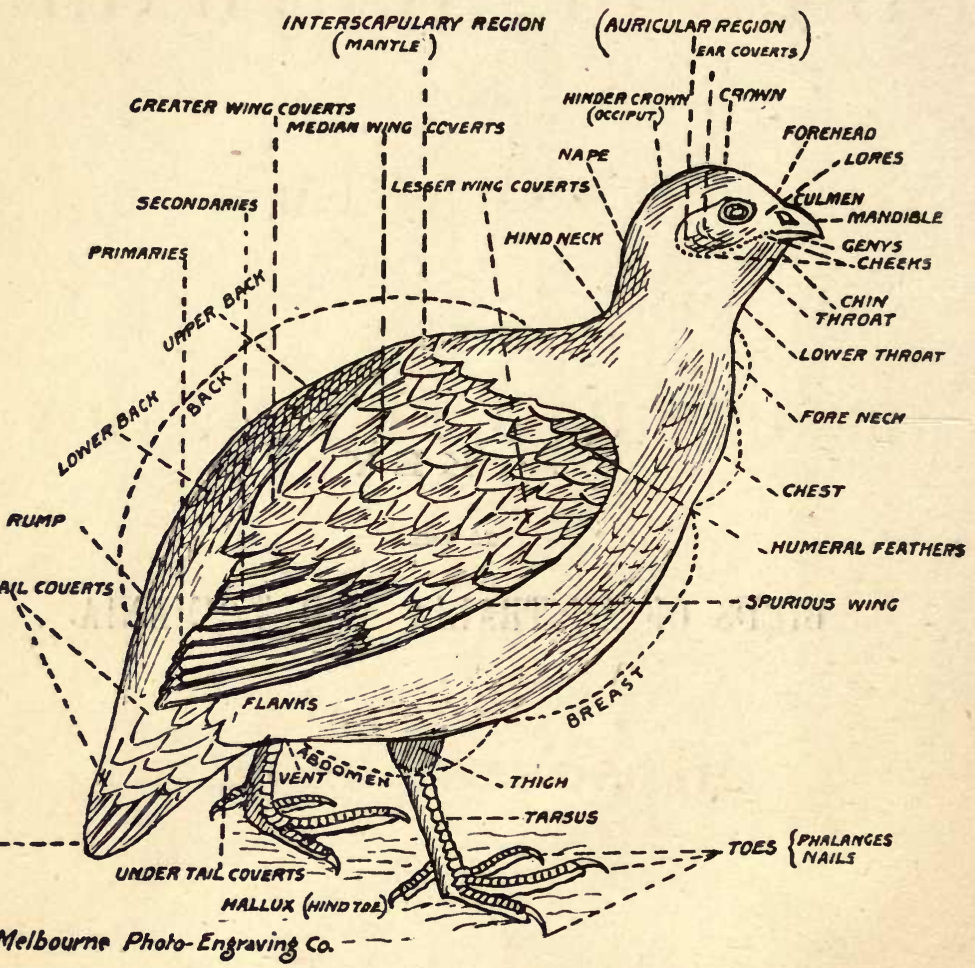

FIGURE OF A BIRD, SHOWING ITS PRINCIPAL EXTERNAL CHARACTERS (QUAIL-DIAGRAMMATIC). 


\title{
A $K E Y$
}

TO THE

\section{BIRDS OF AUSTRALIA}

\author{
AND
}

T A S M A N I A

WITH THEIR

GEOGRAPHICAL DISTRIBUTION

IN AUSTRALIA

\section{BY ROBERT HALL}

arefbontrme

MELVILLE, MULLEN AND SLADE, COLLINS STREET

Sonbon

DULAU AND CO., 37 SOHO SQUARE

[COPYRIGHT] 

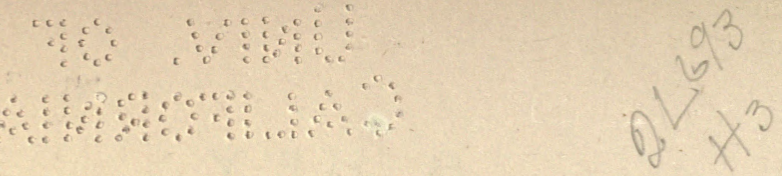

BHOLOG:

LIBRARY

G

MELBOURNE :

WALKER, MAY AND CO., PRINTERS, MACKILLOP STREET. 


\section{PREFACE.}

$\mathbb{7 F}_{3} \mathrm{HE}$ opportunity to publish a "Key to the Birds of Australia " is practically given in the catalogues of the British Museum dealing with the birds of the world, commenced in 1872 and concluded in the present year. The Key, comprising in each case a concise digest of the 770 species of birds found in Australia and Tasmania, is built principally upon these catalogues. Many descriptions are exactly reproduced, others are added to, and a portion is described from the author's collection. The classification is almost wholly that of the British Museum, while the nomenclature is entirely so. Gould's and Ramsay's names appear as synonyms in nearly all cases, and the most important vernaculars of late use are bracketed after each species.

The systematic work done by Mr. North, of the Australian Museum; has aided me in the digest of the Accipitres.

The geographical distribution of our birds is here placed very much upon the plan of sub-regions defined by Professor Spencer in the "Horn Expedition Report (Zool.)," and it appears to me an appropriate one.

I have consulted with advantage Dr. Ramsay's " Geographical Distribution of Australian Birds," in tabular form. The method of locating the birds adopted here differs from that in so far as subregions, and not colonies and towns, are used. The appendix map indicates the Eyrean, Torresian, and Bassian sub-regions, as proposed by Professor Spencer, and these again are divided into nine areas. The Torresian embraces Ramsay's Northern Territory towns and a portion of Carpentaria in 1; a portion of Carpentaria and North Queensland in 2; South Queensland, with the Richmond and Clarence Rivers, in 3.

The Bassian sub-region welds the eastern parts of New South Wales and Victoria and Tasmania together-the first two as 4 , and the last as 5 .

The Eyrean sub-region includes Central and Western Australia, and the northern and western parts of Victoria and the interior of New South Wales. Dr. Ramsay unites Victoria with South Australia, but I find that the parts of Victoria and South Australia included in the Eyrean region constitute, so far as the avifauna is concerned, one area, designated 6; Central Australia forms area 7; North-West Australia forms area 8 ; and Western Australia forms area 9.

In the allocation of species to definite areas it is to be borne in mind that the boundaries are only those absolutely kept to by the species 
as a whole. In cases in which birds are not what one would call quite common to the areas, the numeral indicating the area is bracketed.

Briefly it may be stated that the stronghold of Australian Passeres lies in area 3, and I will remark upon the distribution of this strong order, because it practicaliy covers the points of geographical interest in the orders of our land birds.

AREA 1.- It is most nearly allied to 2.

Of 54 genera 120 species, there are 6 genera 44 species not represented in 2, 16 genera 84 species not in 7,19 genera 65 species not in 8 .

Genera absent from 2 are Struthidea and Tæniopygia; absent in 7, Oriolus, Pœcilodryas, Piezorhynchus, Chibia, Pitta; absent from 8, Grallina, Oriolus, Snicrornis, Sericornis, Megalurus. Pachycephala simplex, Cracticus argenteus, Climacteris melanonota, and six other species are peculiar to this area. In order Fulicariæ there is one genus (Poliolimnas) not found elsewhere.

AREA 2.-Although not so strong in genera as 3 to the extent of 12 per cent., it has more species (12 per cent.) Of the 76 genera 174 species, there are 13 genera 82 species missing from 3,27 genera 109 species not in 1, 30 genera 121 species not in 7 . Area 7 reciprocates with 00 per cent. less genera common to 2 than are common to 7 and 3.

Genera absent in 3-Craspedophora, Prionodura, Heteromyias, Arses, Calornis [origin Papua, except in Prionodura (?)]; absent in 1, Ptilorhis, Geocichla, Acanthiza, Meliphaga, Meliornis (all present in 3); absent in 7, Cinnyris, Phonygama, Craspedophora, Calornis (all absent in 3 also), Ptilorhis.

It has 30 species and 6 genera peculiar to it, no other area having more than one genus peculiar to it. Although 9 has half as many species, it has no genus of its own (only one beyond the Passeres). It would appear area 2 has been first populated and area 9 the last, as further figures indicate.

The peculiar genera are:-Craspedophora, Phonygama, Heteromyias, Scenopæus, Cinnyris, and Calornis.

AREA 3.-Apparently it expands into 4 and 7, and slightly so into 2 , though from the latter it has probably acquired originally a considerable part of its avifauna. It is represented most strongly in 2 (76 genera 174 species), next in 4 (71 genera 121 species), and less so in 7 ( 65 genera 126 species). The distribution of genera and species from 3 to 2 is continued in a lesser degree fron 2 to 1 , and still more so from 1 to 8 , there largely terminating as the westerly expansion along the northern route. Of the 83 genera and 153 species in 3 , 16 genera and 53 species are wanting in 2,15 genera and 47 species are absent from 4, while 28 genera and 71 species are not in 7 . The number of genera (65) and species (126) in 7 show it-with remarks under 2 and 4 -to be less strongly related to 3 than are 2 and 4 . The genera of 3 -Cinclosoma, Gymnorhina, Acanthorhynchus, Stagamopleura, and Zonæginthus - are absent in 2, though present in 4, while -Pseudogerygone, Pœcilodryas, Plectrorhynchus, Bathilda, and Peophila are in 2 and absent in 4. The genera Eopsaltria, Atrichia, Meliornis, Aelurodus, and Piezorhynchus do not pass into 7 . 
The genus Sericulus is peculiar to 3 , but only two species-Menura alberti and Collyriocincla cerviniventris-are limited to it.

AREA 4.-This is the southern extension of 3 , and with it is closely associated 5; indeed, the latter may be expanded as a southern offshoot of 4. The two areas 4 and 5 , on the other hand, differ in important respects from 6 and 7 . Of the 71 genera 121 species there are 4 genera 28 species absent from $3 ; 21$ genera 52 species absent from $6 ; 25$ genera 66 species absent from 7 . In 5 there are 39 genera 90 species absent. Genera absent-in 3, Pycnoptilus, Monarcha, Calamanthus ; in 6, Oriolus, Myiagra, Sphenura, Psophodes, Atrichia ; in 7, Yycnoptilus, Menura; in 5, Egintha, Ptilonorhynchus, Piezorhynchus, Menura.

The genus peculiar to this area is Pycnoptilus, the species Manorhina melanophrys, Ptilotis cassidix, Menura superba, Menura victoriæ, Sericornis osculans, Pycnoptilus floccosus.

AREA 5.-The insular area of 4 . Of 34 genera 55 species, it does not appear to hold a genus not common with 4, unless Acanthornis (of Legge, Sericornis of other authors) stands alone. The relationship is not so strong with 6 , for while 1 genus 14 species are not in 4 , there are 4 genera 29 species not found in 6.

The reciprocal of 6 to 5 in number of genera and species (36 genera 103 species) is practically the same as that of 4 to 5 (39 genera 90 species). Genera absent in 6, Myiagra, Cisticola, and Stipiturus (all present in 4). Peculiar to the island are 14 species.

AREA 6.-Apparently the relation is to 7, 9, and 4, in that order. The total number of genera is 65, species 117. Absent in 4 are 17 genera 53 species; in 9,11 genera 61 species; in 7,5 genera 24 species. Genera absent-in 4, Drymaœdus, Xerophila, Oreoica, Entomophila, Amytis ; in 9, Corcorax, Lalage, Smicrornis, Stictoptera, Entomyza ; in 7, Eopsaltria, Meliornis, Acanthorhynchus, Pseudogerygone, Chibia (all in 4). The species peculiar to this area are Xerophila pectoralis and Mirafra secunda.

AREA 7.- It has 65 genera and 126 species, and although it appears to be more closely related to 6 , it is closely related to 3 . In this area there are 5 genera 29 species absent from $6 ; 10$ genera 49 species absent in $3 ; 16$ genera 46 species absent in $9 ; 19$ genera 69 species absent in $2 ; 21$ genera 68 species absent in $4 ; 26$ genera 96 species absent in 1; 31 genera 92 species absent in 8 . Area 5 is practically 4.

In the separate areas it will be noticed that the relationship between area 7 and other areas is in the following order :-8, 1, 4, 2, $9,3,6$, area 8 showing the most marked difference, and 6 the strcngest affinity. The closest relationship appears to be to 6 , then $3,9,2,4,1,8$ in order. The boundary between 6 and 7 is not a strong one. In 7, absent from 6, are-Bathilda, Emblema, Aidemosyne, Myiagra, Gerygone ; absent from 3, Struthidea, Amytis, Drymaœdus, Calamanthus, Entomophila; absent from 9, Lalage, Smicrornis, Myiagra, Sphenostoma, Entomyza; absent from 2, Pteropodocys, Acanthochæra, Amytis, Calamanthus, Staganopleura; absent from 4, Chlamydodera, Xerophila, Oreoica, Entomophila, Emblema; absent from 1, Corcorux, Cinclosoma, Acanthiza, Falcunculus, Strepera; absent from 8, Amytis, Sericurnis, Hylacola, Zosterops, Megalurus. There are no known genera peculiar to 7. The following species are not beyond it:-Rhipidura albicauda, Amytis goyderi, Calamanthus isabellinus, Xerophila nigricincta. 


\section{viii}

AREA 8.- It is most closely related to 1. Of the 45 genera 76 species there are 5 genera 20 species absent from 1; 6 genera 37 species absent from $7 ; 13$ genera 50 species not in 9 . Area 9 seems to repel $8 ; 8$ is in strong sympathy with 1 , and slightly so with 7. Genera absent in 1, Emblema, Amytis, Acrocephalus (the only gap); in 9, Cisticola, Philemon, Myiagra, Munia, Peophila ; in 7 , Stipiturus, Pœcilodryas, Neochmia, Munia. The following species are peculiar to this area:-Malurus coronatus, Gerygone cinerascens, Stipiturus ruficeps, Cinclosoma marginatum, Pachycephala lanioides.

AREA 9.-It has 59 genera 93 species, and seems to be derived in two ways-from 6 and 7 . Genera in 9 absent from 6 are-Psophodes, Atrichia, Stipiturus, and Sphenura (all in area 4), while those absent in 7 are Stipiturus, Acanthorynchus, Meliornis, Pseudogerygone. From this, and remarks under 6 , it would appear the avifauna of the south-west is largely derived from 6, that of the west proper from 7. The genera here absent from 8 are those strong ones of the east and south-east-Sericornis, Acanthiza, and Zosterops; others being Amytis and Gymnorhina. Three-fourths of the species and half the genera of 9 are absent from 8 . In 9 there are 4 genera (also in 4) and 37 species that are not in 6 , while in 6 there are 11 genera and 61 species that are not in 9 . Present in 9, but absent in 7 , are 7 genera and 36 species, while there are 16 genera and 64 species in 7 absent in 9. To this area there is no Passerine genus peculiar, but there are 17 species. In the order Psittaci there is Porphyrocephalus confined to 9 .

In a more limited way the smaller orders help to support this scheme of distribution, the idea of which was in part suggested by Professor Baldwin Spencer, Hon. Director of the National Museum.

R. $\mathrm{H}$.

Box Hill, Victoria, August, 1899. 


\section{A SYNOPSIS OF THE ORDERS.}

I.-ACCIPITRES.-Birds of Prey. Bill short, strong, stout at the base, the culmen strongly curved. Feet strong, armed with powerful talons; talons capable of being bent under the feet, the inner one being stronger than the others and more curved

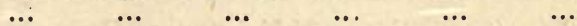

II.-PASSERES.-Perching Birds proper. Palate ægithognathous. Vomer is broadened and blunt or truncated at the anterior end. Maxillo-palatines widely separated

PAGK

III.-PICARI E. - This is an order opposed to the Passeres, pri-
marily on account of the relatively smaller and weaker feet
in the Australian forms (example, Podargus). It is pro-
visional $\quad .$.

III.-PICARIA. - This is an order opposed to the Passeres, pri-
marily on account of the relatively smaller and weaker feet
in the Australian forms (example, Podargus). It is pro-
visional
...

III.-PICARIA. - This is an order opposed to the Passeres, pri-
marily on account of the relatively smaller and weaker feet
in the Australian forms (example, Podargus). It is pro-
visional
...

III.-PICARIA. - This is an order opposed to the Passeres, pri-
marily on account of the relatively smaller and weaker feet
in the Australian forms (example, Podargus). It is pro-
visional
...

IV. -PSITTACI. - Feet permanently zygodactyl by reversion of the fourth toe, covered with plates. Bill short and very stout, strongly hooked or epignathous, and furnished with a cere

V.-COLUMBæ.-Pigeons. Rostrum swollen at the tip, convex; its basal portion has a soft skin, in which lie the nostrils, with a valve over them. Tarsi covered fore and rear with hexagonal scales. Palate schizognathous. Nostrils schizo$\begin{array}{lllllll}\text { rhinal } & \ldots & \ldots & \ldots & \ldots & \ldots & \ldots\end{array}$

VI.-GALLIN AE.-Bill short and stout, the culmen arched and overhanging the mandible. Maxillo-palatines not coalesced ...

VII.-HEMIPODII.-Button Quails, opposed to True Quails. Feet with three toes (except Pedionomus, which has the hallux). Maxillo-palatines not coalesced with one another ... ...

VIII.-FULICARIE._-Rails. The characters are osteological (Catalogue Fossil Birds, pp. 143 and 144, Lydekker) ... ...

IX.-ALECTORIDES.-True Crane (Native Companion) and Bustard, in Australia. The angle of the mandible is always truncated. The hind toe is raised above the level of the other toes. [Mesites (extra-Australian) excepted] ... ...

X.-LIMICOLA.-Palate schizognathous. Primaries eleven, fifth secondary wanting. After shaft to the contour feathers $\begin{array}{lllllll}\text { present } & \ldots & \ldots & \ldots & \ldots & \ldots & \ldots\end{array}$

XI.-GAVI E.-Front toes entirely connected by webs. Primaries, ten large and visible, one minute and concealed. Rectrices twelve. Palate schizognathous. Nasals schizorhinal .. 
XII.-TUBINARES.-External nostrils are produced into tubes. Anterior toes are fully webbed; hallux small or absent. Palate schizognathous. Nasals holorhinal.

..

XIII.-PLATALEF.-Ibis and Spoonbill. Posterior angle of mandible recurved. Edge of cranium above the orbits truncate, indicating the position of the nasal glands ... ...

XIV.-HERODIONES. - Heron-like Birds. Hallux free, not united to the other toes by a web. Nasals holorhinal. Palate desmognathous

XV.-STEGANOPODES.-Hallux united to the other toes by a web. Nasals holorhinal. Palate desmognathous

XVI.-PYGOPODES.-Grebes in Australia. Wing feathers developed into remiges. Cnemial process of tibia produced forwards in a remarkable degree. Palate schizognathous ...

XVII.-IMPENNES.-Penguins. Bill never hooked. Nostrils pervious, holorhinal. Palate schizognathous ... ...

XVIII.-CHENOMORPHA.-'Swans, Geese, and Ducks. Palate desmognathous. Young covered with down, and able to run or swim in a few hours after hatching

XIX. - CASUARII. - Emu-like Birds. Hallux absent ; middle phalanges shortened. Maxillo-palatines large, fused with vomer and premaxilla 


\section{ERRATA AND ADDENDA.}

Species 80. "White-billed" should read "White-bellied."

Genus Prionodura, species 60 (Golden Bower-bird) should follow species 172.

Species 46 should read "Hab. 2, 3, 4."

Species 82 should read "Hab. 2, 3, 4."

Species 346 should read " Hab. 3, 4, 6, 7."

Species 381 should read " Hab. 1, 2, 3, 7, 8."

Species 360 should read “ Hab. 3, 4, 5, 6."

Species 370. " Hab. 11 " should read "Hab. 7."

Species 389. "Hab. 11 and 14 " should read "Hab. 7 and 9."

Page 5, line 16 from bottom, "or middle toe" should read " of middle toe."

Page 6, line 19 from bottom, "claw or" should read "claw of."

Page 112, Index to Genera, add "Stigmatops (Glycyphila), 39, 40."

Map of Distribution. Area 1: The words Northern Territory (Proper) apply here to birds. Area 6 includes adjacent area of New South Wales. 


\section{CLASS-AVES. \\ SUB-CLASS I.-CARINATE}

(STERNUM KeELed).

ORDFR-ACCIPITRES (BIRDS OF PREY).

Bill short, strong, stout at the base, the culmen strongly curved. Feet strong, armed with powerful talons; talons capable of being bent under the feet, the inner one being stronger than the others and more curved.

\section{Sub-order-Falcones.}

With no facial disc; plumage compact; nostrils generally not concealed by bristles; outer toe not reversible ; toes devoid of feathers.

\section{FAMILY-FALCONID E.}

Head covered with feathers, though the sides of the face are more or less bare.

\section{SUB-FAMILY-AQUILINE.}

Hinder aspect of tarsus reticulate ; commissure of bill simply festooned.

GENUS-UROAËTUS. - Tail strongly grarluated.

1. U. audax, Latham (Aquila audax, Gray), Wedge-tailed Eagle (Eaglehawk).

General colour, black in adult, rufous in young. Total length, 38 in. ; culmen, 3 in.; wing, $24 \cdot 2$ in. ; tail, $17 \cdot 5$ in. ; tarsus, $4 \cdot 8$ in. Hab. : 1 to 9 .

GENuS-NISAËTUS.-Tail nearly square, the difference in length of middle and outer tail feathers inappreciable.

2. N. morphnoides, Gould (Aquila morphnoides), Little Eagle.

Rufous beneath, each shaft streaked blackish. Total length, 21.5 in.; bill, 1.75 in. ; wing, 15 in. ; tail, 9.5 in. ; tarsi, $2 \cdot 75$ in.

Hab. : 2, 3, 4, 6, 7, 9.

Genus-HALIAËTUS.-Tarsi bare on lower portion : nostrils more or less perpendicular ovals, with bony margin all round.

3. H. leueogaster, Gmelin, White-bellied Sea Eagle.

Head and under surface white; bill leaden blue; wing not exceed. ing 24 in.

Young.-Head buff; upper surface and wings chocolate brown; chest and abdomen buffy brown.

Hab. : 1 to 9.

GENUS-HALIASTUR.-Tarsi bare on lower portion; nostrils circular, with bony margin all round.

4. II. girrenera, Vieillot (H. leucosternus, Gld.), sub-sp. of H. indus, White-headed Sea Eagle.

Back and abdomen rich chestnut; head and neck white; tail maroon, with broad whitish tip.

Young.-Head, breast, and abdomen brown, with long white streaks.

Hab. : 1 to 4,8 . 
5. II. sphenurus, Vigors, Whistling Eagle.

Under surface sandy, with dark shafts; tail uniform ashybrown; head and neck sandy coloured, with fulvous streaks.

Young.-Less rufous ; white spots and streaks.

Hab. : 1 to 4,6 to 9 .

Genus-MILVUS.-Nostrils oblique, almost linear; distance from angle of mouth to anterior margin of nostril greater than distance from latter point to tip of beak ; tail forked, outer feather longest.

6. M. affinis, Gld., Kite.

Blackish above, rufous below; head and throat brownish, with central stripe ; wing under 16 in.

Hab. : 1, 2, 3, 6 to 9 .

GeNUS-LOPHOICTINIA.-Nostrils oblique, almost linear ; distances as measured in Milvus equal ; tail slightly forked, outer tail feather longest.

7. L, iswra, Gld., Long-winged Kite (Square-tailed Kite).

Blackish-brown above, reddish-orange below; head shafts conspicuously marked.

Hab. : $3,6,7,9$.

Gends-GYPOICTINIA.-Nostrils oblique, almost linear ; tail rounded, outer feather shorter than middle one; ridge of bill (without cere) greater than half of middle toe (without claw); wings reaching to end of tail ; bare part of tarsus in front greater than half of middle toe (without claw).

8. G. melanosterna, Gld., Black-breasted Buzzard.

Head and breast black. Adult male-Total length, 24 in. ; culmen, 2.45 in. ; wing, 19 in. ; tail, 8.5 in. ; tarsus, 2.65 in. ; middlé toe, 1.95 in.

Hab. : 6 to 9 .

GeNus-ELANUS.-Bare part of tarsus in front less than middle toe.

9. E. axillaris, Lath., Black-shouldered Kite.

General colour plumage greyish white, shoulder black, axillaries white.

Hab. : 1 to $4,6,7,9$.

10. E. scriptus, Gld., Letter-winged Kite.

Plumage greyish-white; axillaries and broad bar across under wing coverts black.

Hab. : 3, 4, 6, 7, 9.

\section{Sub-FAMILY-FALCONINA.}

Hinder aspect of tarsus reticulate; commissure of bill distinctly notched.

$$
\text { Gexus-BAZA.-Head crested. }
$$

11. B. subcristata, Gld., Crested Hawk.

Head and neck ashy-grey, with small occipital crest of black feathers; rest of upper surface brown, the wing coverts and interscapular region greyish-black; quills dark brown, broadly barred with black above and with greyish-white under; tail ashy-brown, with four black bars ; forehead, lores, and sides of face clearer ashy than head, as also the throat and chest, the chest washed with rufous, the breast banded alternately with buffy-white and chestnutbrown. Total length, 17 in.; bill, 1.2 in.; wing, 13.5 in. ; tail, 9 in. ; tarsus, 14 in.

Hab. : $1,2,3,7$. 
Genus-FALCO. - Distance between tips of primaries and tips of secondaries more than half length of tail.

12. F. melanogenys, Gld., Black-cheeked Falcon.

Male.-Head, entire sides of face, cheeks, ear coverts deep black, upper surface blackish-brown, quills blackish, the outer secondaries with white tips; throat creamy; upper breast creamy with black stripes, rest of under surface buffy-white with close narrow bars. Thighs transversely barred. Total length, 15 in. ; wing, 11.75 in.

Female.-Similar but larger; underneath deep rusty, paler on chest.

Hab. : 2 to 9.

13. F. hypoleucus, Gld., Grey Falcon.

Thighs perfectly uniform, whitish or bluish-white. Above ashy, all feathers with blackish centres; under surface of body entirely white, with buff shade on flanks and under tail coverts; throat unspotted, but rest of feathers underneath narrowly striped, except thighs.

Total length, male 12 in., wing 11 in., tail 6.25 in. ; female 15 in., wing 12.5 in., tail 6.5 in.

Hab. : 1, 2, 3, 6, 7.

14. F. subniger, Gray, Black Failcon.

General colour plumage sooty-brown; thighs perfectly uniform sooty-brown, like breast.

Total length, male 17 in., wing 14.25 in.; female 19.5 in., wing $15 \cdot 75$ in.

Hab.: 3, 4, 6, 7.

15. F. Iunulatus, Lath., Little Falcon (White-fronted Falcon).

Throat white; breast and abdomen rufous; thighs perfectly uniform rufous.

Total length, male 11.5 in., wing 9.75 in.; female 13.5 in., wing $10.5 \mathrm{in}$.

Hab. : 1 to 9 .

GENus-HIERACIDEA.-Tarsus transversely plated near base of toes.

16. II. berigora, Vig. and Hors., Striped Brown Hawk.

Upper surface sandy-brown, feathers of lower back and rump tipped with rufous; under surface of body creamy-white, with fine brownish shaft stripes; cere pale yellow. Large amount of white on under surface.

Hab. : 6 to 9 .

17. H. orientalis, Schlegel, Brown Hawk.

Above brown; under surface of body creamy-buff to blackishbrown; cere blue-grey.

Hab.: 1 to 9.

GENUS-CERCHNEIS.-Distance between tips of primaries and tips of secondaries greater than half the length of tail.

18. C. cenchroides, Vig. and Hors. (Tinnunculus cenchroides), Kestrel.

Tail rufous, barred with black and tipped with white; head rufous, narrowly streaked with black. Total length, 11.5 in.; culmen, $0 \cdot 7$ in. ; wing, $9 \cdot 3$ in.; tarsus, 1.5 in.

Hab. : 1 to 9 .

\section{Sub-Family-Accipitrine : Long-Legged Hawks.}

Genus-CIRCUS.-Nostrils oval, with no bony excrescence.

19. C. assimilis, Jardine and Selby (C. jardinii, Gld.), Spottéd Harrier.

Above bluish slate colour, feathers of back and wing coverts with white margins, crown of head brick-red, facial ruff pale bluish-grey ; under surface of body rufous, with white rounded spots. 
Young.-Ashy-brown above; upper tail coverts white, washed with rufous, and having dark brown centres; tail brown, with buff tips, and crossed with six black bars.

Hab.: 1 to 9.

20. C. gouldi, Bonaparte (C. assimilis, Gould's Handbook), Gould's Harrier, or Swamp-hawk.

Earthy-brown above, most feathers of back with darker brown centres; upper tail coverts white, with rufous spot on some; tail ashy-grey, tipped with white, the central feathers entirely grey ; thighs white, with rufous streaks; breast white, with brown stripes.

Young.-Uniform sooty-brown above; upper tail coverts rufous ; wings brown, like back ; under surface of body brown, chestnut on abdomen, thighs, and under tail coverts ; tail nearly uniform brown tipped with buff.

Hab. : 1 to 9.

Genos - ASTUR. - Hinder aspect of tarsus scaled; rilge of bill measured from anterior margin of cere is greater than half length of middle toe (without claw).

21. A. cinerens, Vieill., Grey Goshawk.

Upper surface ashy-grey, breast white, tail ashy-grey. Hab. : 1 to 9 .

22. A. nova-hollandiae, Gmelin, White Goshawk.

Under surface white, with bars ; slate above ; tail uniform white ; wing in male 10.5 in., in female 12.5 in.

Hab. : 2 to 6.

23. A. leucosomus, Sharpe (sub sp.), Lesser White Goshawk.

Tail uniform white. Wing in male 7.75 in., variable (Aust. Mus. Cat., No. 4, part i., p. 12).

Hab. : 2.

24. A. approximans, Vig. and Hors., Goshawk.

Underneath brown, with white cross-bars.

Female.-Total length, 20 in.; wing, 12.25 in. ; tail, 10 in. Male.-Total length, 15 in. ; wing, $10 \cdot 25$ in. ; tail, $8 \cdot 5$ in.

Hab. : 1 to 9.

25. A. cruentus. Gld. Chestnut-coloured Goshawk.

Underneath white, with pale rufous cross-bars (Sharpe). Adult Male.-Distinct rufous collar on hind-neck; throat ashy-white, slightly mottled with bluish-grey; remainder of under surface, under wing, and tail coverts barred alternately with narrow lines of rufous and white. the rufous bars the broader ; tail ashy-white below, with from 12 to 15 narrow black bars on feathers, the centre two having spots on shaft lines (Ramsay, 1890).

Hab.: 8.

GENOS-ACCIPITER.-Ridge of bill measured from margin of cere is less than half middle toe (without claw).

26.-A. cirrhocephalus, Vieill., Sparrow-hawk.

Total length, female 14 in., wing $9 \cdot 25$ in., tail 7 to $7 \cdot 5$ in., tarsus

2.5 in. ; male 12 in., wing 8.25 in., tail 6.5 in., tarsus 2.25 in.

Female may be distinguished from male of Astur approximans by

its short tail, never nore than $7 \cdot 5$ in., and slender middle toc.

Hab. : 2,4 to 8 . 


\section{SUB-FAMily - BUteonine.}

Hinder aspect of tarsus scaled.

Gexes-UROSPIZIAS.-Ridge of bill (without cere) less than half the length of middle toe.

27. U. radiatus, Lath. (Astur radiatus), Red Goshawk.

Upper surface of body and wings (excepting quills) bright rufous, feathers of head and neck having a black stripe down centre, all the others centred with black and broadly margined with bright rufous ; throat buff tinged with rufous and each feather striped with black; whole of under surface of body bright deep rufous, each feather (except the axillaries, thighs, and under tail coverts) centred with black streak ; tail below ashy-white crossed with bars of blackishbrown ; upper surface of tail dark ashy-brown, crossed with (12 or more) wavy bars of blackish-brown.

Total length, male 20 in., wing 14 in., tail 9 in., tarsus 3 in.; female 22 in., wing 16 in.

Hab. : 2, 3, 7 .

\section{Sub-order-Pandiones.}

Outer toe is reversible.

Genus-PANDION.-Distance between tips of primaries and tips of secondaries greater than length of tarsus.

28. P. leucocephalus, Gld. (sub-sp. of P. haliaëtus), Osprey or Fishhawk.

Crown of head, back of neck, throat, abdomen, thighs, and under tail coverts white.

Hab. : 1 to $6,8,9$.

\section{Sub-order-Striges.}

Outer toe reversible; eyes directed forward and encircled by a facial disc; nostrils generally hidden by stiff bristles; plumage soft and fluffy ; tibia more than double the length of tarsus.

\section{FAMILY-BUBONID王.}

Hinder margin of sternum with two or more distinct fissures or clefts; furcula free, not attached to keel or sternum ; inner margin of claw or middle toe not serrated; middle toe always longer than the inner one.

\section{SUB-FAMili-BUBONine.}

Ear conch not larger than the eye, without an operculum; facial disc unequal, the portion below the eye being always much greater than the area above the latter.

Genus-NINOX. - Tarsus not twice the length of middle toe.

29. N. boobook, Lath. (includes N. marmoratus), Boobook Owl. General colour rufous; interscapulium not spotted; darker coloured and larger than sub sp. N. ocellata. Wing, 10.3 in. Hab. : 2 to 4, 6, 7, 9.

30. N. ocellata, Hombr. and Jacq. (sub-sp. of N. Boobook), Marbled Owl.

Interscapulium not spotted; more rufous and sinaller than $\mathrm{N}$. boobook. Wing, $9 \cdot 3$ in. Hab. : $1,(7), 8,9$. 
31. N. maculata, Vig. and Hors., Spotted Owl.

General colour rufous-brown and spotted; interscapulium spotted. Hab. : 3, 4, 5 .

32. N. connivens, Lath., Winking Owl.

Breast dull white, streaked, each feather broadly centred with dark colour.

Total length, 16 in. ; wing, 11.9 in. ; tail, $7 \cdot 3$ in. ; tarsus, 1.9 in. ; culmen, 1.6 in.

Hab. : 2, 3, 6, 7, 9.

33. N. occidentalis, Ramsay, Western Winking Owl.

Western form of $\mathbf{N}$. connivens ; upper surface lighter. Hab. : 8.

34. N. peninsularis, Salvad., Cape York Owl.

Smaller than N. connivens; rufous streaks on lower parts. Hab. : 2.

35. N. strenua, Gld. (British Museum Catalogue includes Athene rufa of Ramsay's List), Powerful Owl.

Breast spotted or transversely barred. Total length, 24 in.

Hab. : 1 to 4

36. N. rufa, Gld. (Athene rufa), Rufescent Powerful Owl.

Ear coverts brown, indistinctly streaked with white; thirteen pale bars across tail feathers.

Hab. : 1 .

37. N. humeralis, Hombr. and Jacg., Rufous Owl.

Ear coverts black; tail feathers crossed with eight pale-brown bars (A. J. North).

Total length, 18 in. ; wing, 13.4 in. ; tail, 9 in. ; tarsus, $1 \cdot 8$ in. $\mathrm{Hab}: 2$.

38. N. Iurida, De Vis, Lurid Owl.

Much smaller than N. boobook ; throat, upper portion of breast, axillaries, and under wing coverts with intense rufous colouring. Wing, $8 \cdot 5$ in.

Hab. : 2.

\section{FAMILY -STRIGIDAE.}

Hinder margin of sternum entire, with an emargination but no distinct cleft ; furcula joined to keel of sternum; inner margin of claw or middle toe serrated; inner and middle toes about equal in length.

GENUS-STRIX.-Tarsus about equal to twice length of middle toe.

39. S. flammea, Linn. (sub.sp. delicatula, Gld.), Delicate Owl.

Under surface white, with brown spots; upper surface always vermiculated.

Hab. : 1, 2, 3, 7, 8, 9.

40. S. novae-hollandiae, Stephens, Masked Owl.

Brown and buff, with white spots. Facial disc purplish, but margined with deep brown spots.

Total length, male 13.5 in., wing 12 in.; female 17 in., wing 14 in. Hab. : $1,2,3,7,9$.

41. S. castanops, Gld. (sub-sp. of novæ-hollandiæ), Chestnut-faced Owl.

Rufous brown, barred and spotted above; spotted below. Facial disc deep chestnut, becoming deeper at margin and encircled with black.

Total length, male 14.5 in., wing 12 in. ; female 17 in., wing 15 in. Hab. : 4, 5 . 
42. S. tenebricosa, Gld., Sooty Owl.

Sooty, with white spots. Facial disc sooty-grey, becoming much deeper round eyes.

Total length, male 13.5 in. to 15 in., wing 10.5 in.; female 13 in. to 16 in., wing 10 in. to 12.5 in.

Hab.: 1 to 4.

43. S. candida, Ticknell, Long-legged Owl (Grass Owl).

Upper surface uniform brown, with spots of white; under surface similar. Tarsus, $3 \cdot 5$ in.

Hab. : 1, 2, 3, 6.

\section{ORDER-PASSERES.}

Palate ægithognathous. (Vomer is broadened and blunt or truncated at the anterior end ; maxillo-palatines widely separated.)

\section{DIVISION I.-ACROMYODI.}

\section{Subdivision I.-Passeres Normales.}

\section{SECTION A.-TURDIFORMES.}

Typical or Thrush-like passeres. Wing with ten primaries, the first more or less markedly reduced in size.

\section{Group-Coliomorphæ.}

Angle of chin produced very far forwards, so as to extend beyond the line of the anterior margin of the nasal suture.

\section{FAMILY-CORVID $\circledast$.}

Bill without a distinct subterminal notch in the upper mandible; toes normal, the hallux very strong, but with its claw not as long as the middle toe and claw.

\section{SUB-FAMily-Cokvina.}

Nostrils placed high in the maxilla, as near to or nearer the culmen than the edge of the maxilla.

GeNuS-CORVUS.-First primary is long, equal to or exceeding the innermost secondaries.

44. C. coronoides, Vig. and Hors., Crow.

Plumage uniform blue-black. The neck and body feathers are snow-white at the bases.

Hab. : 1 to 8.

Genus-CORONE.-First primary is longer than ordinary secondaries but shorter than the inmost secondaries.

45. C. australis, Gld., Raven.

Plumage uniform blue-black. The bases of feathers are duskybrown or black, not snow-white.

Hab.: 1 to 9.

GENUS-STREPERA.-Nostrils bare. General appearance black or grey, marked in one to three regions with white.

46. S. graculina, White, Pied Crow-Shrike.

Quills with white tip (if present) not exceeding 1-in. in breadth; base of tail white; white wing speculum; under tail coverts white.

Hab. : 1 to 4 . 
47. S. arguta, Gld., Hill Crow-Shrike.

Quills with white tip (if present) not exceeding 1-in. in breadth ; base of tail blackish; no white wing speculum; base of inner web of primaries white; tail more than 10 in. long.

Hab. : 5.

48. S. intermedia, Sharpe, Lesser Crow-Shrike.

Quills with white tip (if present) not exceeding 1 -in. in breadth ; base of tail blackish; no white speculum at exterior base of primaries; base of inner web of primaries white; tail does not exceed $8 \frac{1}{2}$ in. in length.

$$
\text { Hab. : 4, } 6 .
$$

49. S. cuneicaudata, Vieill., Grey Crow-Shrike.

Wings black, secondaries margined with grey and tipped white; basal half of inner webs of primaries white; tail black, margined with grey and tipped white; tail does not exceed $8 \frac{1}{2}$ in.; under tail coverts white.

$$
\text { Hab. : 3, 6, } 7 .
$$

50. S. plumbea, Gld. (sub-sp. of S. cuneicaudata), Leaden Crow-Shrike.

Deep leaden grey, very little paler below; quills as in cuneicaudata but much blacker, as also primary coverts; tail does not exceed $8 \frac{1}{2}$ in.

Hab. : 9.

51. S. melanoptera, Gld., Black-winged Crow-Shrike.

Quills not broadly tipped with white; base of tail blackish; primaries entirely black below; no white at all at base of inner web; under tail coverts white.

Hab. : 4, 6.

52. S. fuliginosa, Gld., Sooty Crow-Shrike.

Quills with white tips nearly $1 \frac{1}{2}$ in. broad; under tail coverts blackish; general plumage sooty-black.

Hab. : 4, 5, 6.

\section{Genus-STRUTHIDEA-Bill conical.}

53. S. cimerea, Gld., Grey Jumper.

General colour grey, both above and below; wings pale brown, darker on inner webs of quills and centres of wing coverts; tail glossy black; lining of wing pale ashy-brown; iris white.

Total length, 12.5 in. ; bill, 1 in. ; wing, 6 in. ; tail, 6 in. ; tarsus, 1.5 in.

$$
\text { Hab. : 1, 6, } 7 \text {. }
$$

\section{SUb-FAMily-Fregiline.}

Nostrils placed low in the maxilla, nearer to its lower edge than to the culmen.

$$
\text { GeNus-CORCORAX. - Wings rounded. }
$$

54. C. melanorhamphus, Vieill., White-winged Chough.

General colour black; inner webs of primaries, except bases and tips, white ; iris scarlet.

Total length, 16 in.

Hab.: 2, 3, 4, 6, 7 .

\section{FAMILY-PARADISEID $Æ$.}

Toes abnormal, outer toe a little shorter than the middle one, longer than the inner one; hallux very large, with its claw equal to or longer than the middle toe with its claw. 


\section{SUb-FAMiLY-EpinaChine.}

Bill elongated and slender; culmen longer than tarsus.

GeNus-PTILORHIS._Flank feathers rounded, with metallic or

55. P. paradisea, Linn., Rifle-bird. glossy tips.

(a) Larger ; chest purple ; gular shield metallic green ; breast and abdomen olive rifle green; chin and sides of throat black with scarcely any purple gloss. Female buff beneath, with distinct subterminal bands of black.

Hab. : 2, 3.

56. P. victoriae, Gld., Victoria Rifle-bird.

(b) Smaller; chin and sides of throat with a reflection of burnished copper; gular shield somewhat smaller, the purple colour extending over the fore-neck, chest, and upper breast; remainder of under surface more of an olivaceous green. Female fawn colour below, with dusky spots.

Hab.: 2.

GeNus-CRASPEDOPHORA.-Flank feathers elongated into silky plumes with hair-like ends.

57. C. magnifica, Vieill., New Guinea Rifle-bird.

Base of culmen not covered by the frontal plumes; breast reddishpurple below the double pectoral band. Female with the head rufous like the back.

Hab.: 2.

5S. C. alberti, Masters (Ptilorhis alberti), Albert Rifle-bird.

Base of culmen bare, not covered by the frontal plumes; breast only green below the pectoral collar. Female with the head ashybrown, the back olivaceous brown.

Hab. : 2.

Sub-Family-Paradiseine.

Bill short and more or less stout; culmen not so long as tarsus.

GENUS-PHONYGAMA.-Pointed tuft of feathers on side of crown.

59. P. gouldi, Gray (Manucodia gouldi), Manucode.

Centre of crown lengthened; ear plumes, lanceolate feathers on side of neck, back, rump, and breast green; shoulders, primaries, and tail purplish-black, as are also the lower abdomen and under tail coverts ; bill and legs black.

Total length, $11 \cdot 5$ in. ; bill, $1 \cdot 25$ in. ; wing, 6 in. ; tail, 5 in. ; tarsus, $1 \cdot 5$ in.

Hab. : 2.

GExus-PRIONODURA.-Outstretched feet reach to about middle of tail.

60. P. newtomiana, De Vis (P. Linn. Soc. N.S.W., vol. vii.)

Above uniform olive-brown; beneath impure grey ; under surface of wing with base of inner webs of primaries and entire inner webs of secondaries broadly edged with pale sulphur-yellow; under surface of shafts of wing and tail feathers yellow. Female olive and grey.

Length, $8 \cdot 25$ in. ; wing, $11 \cdot 5$ in.

Hab. : 2.

\section{FAMILY-ORIOLID $A$.}

Bill with a notch in the upper mandible; nostrils placed well in front of the base of the bill and quite bare.

GENUS-ORIOLUS. - Lores are feathered.

61. D. flavicinctus, King (Mimeta flavicincta), Yellow Oriole.

Upper surface yellow and black; breast streaked; belly uniform olive-yellow.

Hab. : $1,2$. 
62. O. viridis, Lath. (Mimeta viridis), Oriole.

Upper surface olive; breast streaked; belly white, broadly streaked with black.

Hab : 3, 4.

63. D. affinis, Gld. (Mimeta affinis), Northern Oriole.

Differs from 0 . viridis in having a smaller body, a shorter wing, a much larger bill, and in the white spots at tip of tail being smaller. Considered by Dr. Sharpe to be a very doubtful species. Hab. : 1, 2, 3.

GENUS - SPHECOTHERES. - Lores and region around and behind eye bare.

64. S. maxillaris, Lath. (S. australis, Swainson), Fig-bird.,

Adult Male.-Above yellowish-green; tail black, the three outer feathers white at tip ; crown of head, nape, and ear coverts black, as also fore part of cheeks ; hind-neck, sides of neck, throat, and fore-neck leaden-grey ; rest of under surface dull yellowish-green ; iris varies from dark brown to red. 1 in.

Total length, $9 \cdot 5$ in. ; bill, 1 in. ; wing, 6 in. ; tail, $4 \cdot 5$ in. ; tarsus,

Hab. : 1 to 4.

65. S. flaviventris, Gld., Yellow-bellied Fig-bird.

Adult Male.-Above yellowish-green; tail feathers black, the centre ones entirely black, the outer web of outermost almost entirely white; nape and cheeks black; entire under surface of body bright yellow. Total length, 10.2 in.; bill, 1 in. ; wing, 5.6 in. ; tail, $4 \cdot 4$ in. ; tarsus, 1 in.

Adult Female.-General colour above brown; head light brown; crown and cheeks streaked darker brown; under surface of body white, with brown streaks.

Hab. : : $1,2$.

\section{FAMILY-DICRURID $Æ$.}

Tail forked, consisting of ten feathers; bill with a notch in the upper mandible.

Genus-CHIBIA.-Tip of outer tail feather recurved.

66. C. bracteata, Gld., Drongo.

Metallic shade on neck hackles and on the spangles of the breast steel-green ; loral plumes only moderately dense.

Hab. : 1 to $4,(5), 6$.

\section{FAMILY-PRIONOPIDA.}

Bill with a notch in the upper mandible; tail moderate, rounded or square, consisting of twelve feathers.

SUB-FAMILY - Prionopine.

Bill broader than it is high.

Gexus-GRALLINA.-Second primary longer than the secondaries.

67. G. picata, Lath., Magpie Lark.

Throat white in female, black in male ; breast black, under parts pure white.

$$
\text { Hab. : } 1 \text { to } 4,6,7,9 .
$$

GeNus-COLLYRIOCINCLA.-Conspicuous colours, grey to buff. Second primary longer than secondaries.

68. C. harmonica, Lath., Grey Shrike-Thrush.

Bill blackish; back umber-brown, contrasting with grey head and rump; bill stout, 0.9 in. long; white loral spot very distinct; no eyebrow in adult.

Hab.: 2, 3, 4, 6, 7 . 
69. C. rectirostris, Jardine and Selby, Whistling Shrike-Thrush.

Bill blackish ; back brown, contrasting with grey head and rump ; bill very long, 1.2 in.; white loral spot faint ; distinct eyebrow. Hab. : 5 .

70. C. brunnea, Gld. (includes C. superciliosa, Masters), Brown Shrike'Thrush.

Bill blackish ; back ashy·brown, like rest of upper surface ; under tail coverts white.

Hab. : $1,2,8$.

71. C. rufiventris, Gld., Buff-bellied Shrike-Thrush.

Bill blackish; back ashy-brown, like rest of upper surface ; under tail coverts bright fawn buff.

[Female has a distinct rufous eyebrow.-North.] Hab.: 7, 8, 9.

72. C. pallidirostris, Sharpe, Pale-headed Shrike-Thrush.

Bill light yellowish horn colour ; eyebrow indistinct.

British Museunı Catalogue, iii., p. 293.

Hab.: 1, 2.

73. C. cerviniventris, North, Fawn-breasted Shrike-Thrush.

Inland representative of $P$. rufigaster; differs in having slenderer bill and much paler upper and lower surfaces.

Hab. : 3.

74. C. boweri, Ramsay, Bower Shrike-Thrush (includes C. sibila, DeVis).

P.L.S. of N.S.IV., vol. i., p. 50 ; vol. x., p. 244.

Nearest to P. rufigaster, Gld.

Wing, 4 in. ; tail, 3.5 in.

Hab. : Cairns, Q.

GENos-PINAROLESTES.-Second primaries equal secondaries in length.

75. P. parvulus, Gld. (Collyriocincla parvula), Little Shrike-Thrush.

Over eye a distinct white eyebrow; under surface very pale buff; under tail coverts whitish; general colour above ashy-brown, the head rather darker.

Total length, 7.6 in. ; bill, 08 in. ; wing, 3.7 in. ; tail, 3.2 in.; tarsus, 1 in.

Hab. : 1, 3.

76. P. rufigaster, Gld. (Collyriocincla rufigaster and C. parvissima, Gld,), Rusty-breasted Shrike-Thrush.

Adult male, above dull olive-brown; no distinct eyebrow ; under tail coverts deep fawn colour, like rest of breast.

Total length, $7 \cdot 2$ in. ; culmen, 0.8 in. ; wing, 3.5 in. ; tail, 3 in. ; tarsus, 1 in.

Hab. : 3,4 .

\section{Group-Cichlomorphæ.}

Wing with ten primaries, first more or less markedly reduced in size ; angle of chin shortened and not reaching beyond the line of the anterior margin of the nasal suture ; claw of middle toe oblique ; bill notched, with culmen nearly straight, bent at end in arched curve, acuminate ; nostrils placed nearer to cutting edge of mandible than to the culmen.

FAMILY-CAMPOPHAGID $Æ$.

Birds of soft plumage ; feathers of lower back and rump with stiffened shafts ; bill moderately hooked and notched ; nostrils hidden ; wings in most species lengthened.

GENUS-PTEROPODOCYS.-Tail forked.

77. P. phasianella, Gld., Ground Cuckoo-Shrike.

Head grey ; breast barred.

Total length, 13 in.; bill, 0.75 in. ; wing, 7.5 in. ; tail, 7 in.; tarsus, 1.5 in.

Hab. : 3, 6, 7, 9. 
Gexus-GRAUCALUS. - Bill broad, measured at gape equals outer toe without claw.

78. G. melanops, Lath., Black-faced Cuckoo Shrike.

'Throat black or dark slate colour; forehead feathers round eye, sides of face, and throat black ; fore-neck and breast grey, shading into white on abdomen and under tail coverts. Culmen, 1.05 in.

Young.- Throat and forehead grey. Hab. : 1 to 4,6 to 9 .

79. G. parvirostris, Gld. (sub-sp. of G. melanops), Small-billed Cuckoo-shrike.

Throat black or dark slate colour; forehead feathers round eye, sides of face, and throat black; fore-neck and breast grey, shading into white on abdomen and under tail coverts. Culmen, $0 \cdot 85$ in. Hab. : 5 .

S0. G. hypoleucus, Gld., White-billed Cuckoo-Shrike.

Entire abdomen and flanks pure white; thighs white, with obscure grey bars; hinder eyelid grey ; throat grey.

Hab. : 1, 2, 3.

81. G. mentalis, Vig. and Hors., Little Cuckoo-Shrike.

'Throat grey in adult.

Only lower part of abdomen and under tail coverts pure white; breast entirely grey, like throat ; thighs dark slaty-grey, contrasting with under surface; hinder rim of eyelid white.

During first few months the throat, chest, and back of neck are jet-black, while breast and abdomen are rayed with obscure arrow. shaped black markings on white ground.

Hab. : 1 to 4,6 .

82. G. lineatus, Swainson, Barred Cuckoo-Shrike.

Lower breast and abdomen barred with black and white. Hab. : 5, 6, 7, 10.

GENUS-EDOLIISOMA.-Bill narrower, measured at gape less than outer toe (without claw).

83. E. tenuirostre, Jardine (Campephaga jardinii, Rüpp.), Jardine's Caterpillar-eater.

Adult Male.-Lores black; all upper and under surfaces deep blue-grey; edges of primaries and secondaries, basal three-fourths and tips of outer tail feathers deep blue-grey ; primaries, secondaries, and rest of tail black.

Female has whole of upper surface, wings, and tail brown; the feathers of sides of neck, the breast, and flanks with arrow-head brown marks in centre.

Total length, $9 \cdot 5$ in.; bill, 1 in. ; wing, 5 in. ; tail, $4 \cdot 25$ in.

Young Male.-Bluish-brown above; wings and tail as in female; under surface buff, crossed with numerous black bars.

Hab. : 1 to 4.

Gents-LALAGE.-Wing exceeds tail by length of tarsus,

84. L. tricolor, Swainson, White-shouldered Caterpillar-eater.

Under tail coverts white both in male and female. General colour of male, above black, the wing coverts pure white; tail feathers black, outermost two with white tips; ear coverts, under surface, and under wing coverts white.

Adult Female.-Brown above, the rump feathers and upper tail coverts with narrow white edges; wing coverts and secondaries buff edges; tail brown with white tips; ear coverts with white streaks; cheeks and throat whitish; rest of under body yellowish with obscure cross markings; under wing coverts buffy-white. 
Total length, 6.75 in. ; bill, 0.6 in. ; wing, 5 in. ; tail, 4 in. ; tarsus, 0.8 in.

Hab. : $1,2,3,6,7,8$.

85. I. leucomelaena, Vig. and Hors. (L. karu, Lesson), Pied Caterpillar-eater.

Under tail coverts buff or fawn in both male and female. In male the under surface is uniform. In female under surface of body is fawn (lighter on throat) and crossed with wavy lines of dusky blackish, vanishing on throat, and absent on lower abdomen and under tail corerts, which are more richly coloured.

Hab. : 1, 2, 3, 4 .

\section{FAMILY-MUSCICAPID Æ.}

Bill broadened or rather flat, generally furnished with numerous rictal bristles ; culmen keeled.

Genus-MICRECA.-Wings extremely long; distance between wings and tip of tail not exceeding length of tarsus.

S6. M. fascinans, Lath., Brown Fly-catcher.

Belly and under tail coverts white; outer tail feathers entirely pure white; axillaries light brown. Wing, $3 \cdot 45$ in.

Hab. : (2), 3, 4, 6, 7 .

87. M. assimilis, Gld., Lesser Brown Fly-catcher.

Belly and under tail coverts white; outer tail feathers blackishbrown, white at tip of inner web and along outer one. Wing, $3 \cdot 35$ in. Smaller than M. fascinans.

Hab. : 1, 8, 9.

88. M. flavigaster, Gld., Lemon-breasted Fly-catcher.

Belly and under tail coverts yellow; above olive-brown; throat white or paler yellow; lores dull white. Wing, $2 \cdot 75$ in.

Hab. : 1, 2.

89. M. pallida, De Vis, Pale Fly-catcher.

Roy. Soc. Queensland, vol. i., p. 159 Nearest. to M. fascinans. Hab. : 2, 8 .

Genus-PETRGEA.-Bill about equal in height and breadth at the nostrils.

90. P. leggii. Sharpe (P. multicolor, Swain.), Scarlet-breasted Robin.

Male, upper surface black; frontal white mark large; throat black ; breast scarlet. Female, throat and back grey. Hab. : 2, 3, 4, 5, 6 .

91. P. camploelli, Sharpe.

Male, small white frontal band, and less white on wing than in $\mathrm{P}$. leggii, to which it is closely related.

Hab. : 9.

92. P. phoenicea, Gld., Flame breasted Robin.

Male, upper surface slaty-grey ; frontal mark small ; only the chin black, remainder of throat and breast orange-scarlet. Female, uniform brown above; breast faint red; no red in young.

Hab. : 4, 5 .

93. P. goodenovii, Vig and Hors., Red-capped Robin.

Male, forehead red; throat black. Female, body grey; forehead

" faint scarlet."

Hab. : 6, $7,9$.

94. P. rosea, Gld. (Erythrodryas rosea), Rose-breasted Robin.

Male, wing coverts without any white; breast rose-pink; with white outer tail feathers. Female, spot of buff on forehead; secondaries whitish-buff marked; under surface brown.

Hab. : 2, 3, 4 . 
95. P. ramsayi, Sharpe, Red-throated Robin.

Male, forehead red; throat red in centre. Female, body grey ; forehead dull brick-red.

Hab. : $1,8$.

96. P. rhodinogastra, Drapier (Erythrodryas rhodinogaster), Pinkbreasted Robin.

Male, breast pink; no white in wing coverts or tail. Female, under surface brownish ; faint white spot on forehead ; markings on primaries and secondaries buff.

Hab. : 4, 5.

97. P. bicolor, Vig. and Hors. (Melanodryas bicolor), Hooded Robin.

Under surface white ; insertion of wing white. Male, throat black.

Female, throat ashy; base of tail white.

Hab. : 3, 4, 6, 9 .

95. P. picata, Gld. (sub-sp. of P. bicolor), Pied Robin.

Has less black on tail and more white on inner secondaries than P. bicolor.

Hab. : 1, 7, 8.

99. P. vittata, Quoy and Gaim. (P. fusca, Gld., Amaurodryas vittata), Dusky Robin.

Brownish-olive above; throat dusky-brown; only outer tail feather white at base and for whole extent of outer web; under surface brown.

Young.-Brown, streaked above, mottled below.

Hab. : 4, 5, 6.

GENUS-SMICRORNIS. - Culmen 0.25 in. in length.

100. S. brevirostris, Gld., Short-billed Tree-Tit.

Colour above dull olive-yellow ; lores, eyebrows, and ear coverts light reddish-brown; under surface pale yellowish-buff.

Hab. : 3, 6, 7 .

101. S. flavescens, Gld., Yellow-tinted Tree-Tit.

Colour above pale olive-yellow; lores and eyebrows whitish ; under surface sulphur-yellow.

Hab. : 1, 8, 9.

GEnUS-GERYGONE.-Second primary longer than secondaries.

102. G. albigularis, Gld., White-throated Fly-eater.

Upper surface ashy-olive ; throat white; breast yellow. Wing, $2 \cdot 25$ in.

Hab. : 2, 3, 7, 8.

103. G. cinerascens, Sharpe, Grey Fly-eater.

Upper surface ashy, no olive ; throat white; breast yellow. Wing, $2 \cdot 15$ in.

Hab. : 8.

GENUS-PSEUDOGERYGONE.--Second primary about equal to s scondaries.

104. P. culicivora, Gld., Western Fly-eater (Gerygone).

Abdomen whitish; ear coverts and throat of same colour (grey); subterminal black bar on tail feathers, which are white at base.

Hab. : 9.

105. P. laevigastra, Gld., Buff-breasted Fly-eater.

Has a subterminal black bar on tail ; throat white, like rest of under surface ; ear coverts brown; eyebrows pure white.

Hab. : 1 . 
106. P. fusca, Gld. (Gerygone fusca), Brown Fly-eater.

Has a subterminal black bar on tail ; greyish eyebrow, from lores over fore part of eye ; throat greyish ; ear coverts grey.

Hab. : $3,6$.

107. P. brunneipectus, Sharpe, Black-billed Fly-eater.

Ear coverts reddish-brown (differing from throat); breast and sides of body reddish-brown; bill entirely black; round eye a ring of white ; sub-terminal black bar on tail.

Hab. : 2.

108. P. chloronota, Gld., Green-backed Ely-eater.

Under surface white, the sides of body yellow; no subterminal black bar on tail ; bill with lower mandible yellowish.

Hab. : 1, 2.

109. P. persomata, Gld. (includes G. flavida), Black-throated Fly-eater. Bill entirely black; throat dark; tail uniform brown, without black bar; in male sides of face and throat are brown, contrasting with breast.

Hab. : 2.

110. P. magnirostris, Gld., Large-billed Fly-eater.

Breast and sides of body reddish-brown; ear coverts differ from throat ; no light eyebrow; a white ring round eye ; bill black, but pearly white at base of lower mandible ; throat pale; subterminal black bar on tail feathers.

Hab.: 1, 2.

GENUS-HETEROMYIAS. - Wings very long, falling short of tail by not more than length of culmen; bill higher than it is broad at nostrils.

111. II. cinereifrons, Ramsay, Ashy-fronted Fly-Robin.

Rusty-brown above; chest ashy ; breast and abdomen white.

Total length, $6 \cdot 3$ in. ; culmen, 0.7 in.; wings, $3 \cdot 75$ in.; tarsus, $2 \cdot 75$ in.

Hab. : 2.

GENUS-PCECILODRYAS.-Wings very long, falling short of tail by not more than length of culmen; bill broader than it is high at nostrils.

112. P. cerviniventris, Gld., Buff-sided Robin.

Throat white; flanks and under tail coverts tawny-buff ; abdomen greyish-white.

Hab. : 1, 8.

113. P. superciliosa, Gld., White-browed Robin.

Throat white; flanks and under tail coverts white; abdomen greyish-white.

Hab. : $1,2$.

114. P. albifacies, Sharpe, White-faced Robin.

Whole of region round eye and lores white; forehead blackish, extending over eye; ears slaty-grey; upper surface olive-green; throat and under surface bright yellow.

Hab. : 2.

115. P. mana, Sharpe, Little Robin.

Abdomen yellow, like breast; lores and feathers round the eye rufescent. (Doubtful sp., juv.)

Hab. : 2.

116. P. capito, Sharpe, Large-headed Robin.

Abdomen yellow, like breast; lores and feathers round the eye white.

Hab. : 2, 3. 
GeNUS-MALURUS.-Females have sombre plumage; males brilliant. Tail longer than wing; bill about equal in height and breadth.

117. M. cyaneus, Ellis, Blue Wren.

Head blue; throat blue-black; upper tail coverts black; head, ear coverts, and mantle turquoise-blue.

Hab. : 3, 4.

118. M. gouldi, Sharpe (longicaudus, Gld.), Gould's Blue Wrren. Very like M. cyaneus.

Head blue ; throat blue-black; upper tail coverts black; head, ear coverts, and mantle rich cobalt.blue.

Hab. : 4, 5 .

119. M. melanotus. Gld., Black-backed Wren.

[Throat deep cobalt-blue; band across upper part of breast velvety black; rest of under surface, flank feathers, and under tail coverts cobalt-blue.-North.]

Head blue; throat blue; upper tail coverts blue : wing coverts brown, with bluish edges ; no white shoulder spot; black bar across rump, this and lower back being hlack; crown of head and mantle deep cobalt-blue ; ear coverts turquoise-blue.

Hab. : 6,7 .

120. M. callainus, Gld., Turquoise Wren.

Head, throat, and upper tail coverts blue : wing coverts brown, with bluish edges, no white shoulder; black bar across rump, lower back black : crown of head and mantle greenish turquoise-blue; forehead and ear coverts silvery-white.

Hab. : 6,7 .

121. M. splendens. Quoy and Gaim., Banded Wren.

Head, throat, and upper tail coverts blue; wing coverts brown, with bluish edges; no white shoulder spot; no black bar across rump; upper surface entirely rich cobalt.

Hab.: 9.

122. M. leucopterus, Quoy and Gaim., White-winged Wren.

Head, throat, and upper tail coverts blue; scapularies, wing coverts, and inner secondaries pure white; centre of back blue.

Hab. : $6,7,8$.

123. M. leuconotus, Gld., White-backed Wren.

Head, throat, and upper tail coverts blue; scapularies, wing coverts, and inner secondaries pure white ; centre of back white.

Hab. : 4, 6, 7 .

124. M. elegans. Gld., Red-winged Wren (Graceful Blue Wren).

Head blue ; scapularies chestnut-red; back beautiful silvery-blue, a little lighter than eyebrow or ear coverts.

$\mathrm{Hab}$ : 9.

125. M. lamberti, Vig. and Hors., Variegated Wren.

Head blue; scapularies chestnut-red; back fine cobalt-blue, of a different tint to crown ; ear coverts and eyebrow richer turquoiseblue than blue of nape.

Hab. : 1, 2, 3, 6, 7, 8 .

126. M. amabilis, Gld., Lovely Wren.

Head blue; scapularies chestnut-red; back fine cobalt-blue, of a different tint to crown; ear coverts and eyebrows rich enamelled blue.

In young, throat is creamy.white.

Hab: $1,2$.

127. M. pulcherrimus, Gld., Blue-breasted Wren.

Head blue; scapularies chestnut-red; centre of back purplishblue, like crown; ear coverts more cobalt.

$\mathrm{Hab}: 9$. 
128. M. coronatus, Gld., Purple-crowned Wren.

Head lilac, with black spot in centre of crown.

Hab. : 8.

129. M. melanocephalus, Vig. and Hors., Orange-backed Wren.

Head black, as also the entire under surface; back scarlet-vermilion. Hab. : 3, 7.

130. M. dorsalis, Lewin (M. cruentatus), Red-backed Wren.

Head black, as also the entire under surface; back deep crimson.

Hab. : 1, 2, 8 .

131. M. boweri, Ramsay (M. cruentatus boweri), Bower Red-backed Wren. P.L.S. of N.S.W., vol. i., p. 1,100 (juvenile skin).

Throat and abdomen white; a few crimson feathers on shoulders, back, and rump, the others being light fawn.

Hab. : 8 .

132. M. cyanochlamys, Sharpe, Silvery-blue Wren.

Adult male similar to M. cyaneus, and having head, ear coverts, and mantle of same tint, but the blue much lighter, paler, and of a silvery cobalt instead of the deep cobalt-blue of M. cyaneus (Proc. Zool. Soc. 1881, pp. 788-9).

Hab. : 2, 3 .

GENUS-RHIPIDURA. - Tail longer than wing.

133. R. albiscapa, Gld., White-shafted Fan-tail.

Two centre tail feathers with brown shafts, the rest with white ones; under surface ochreous-buff, the breast uniform; throat white, with a black or grey patch on lower portion; throat mark black. $\mathrm{Hab}: 2,3,4,6,7$.

134. R. albicauda, North, White-tailed Fan-tail.

Similar to R. albiscapa. One or two of outermost tail feathers on each side pure white; two central feathers of tail blackish-brown; other tail feathers white, narrowly edged with brown.

Hab. : 7.

135. R. preissi, Cabani, Western Fan-tail.

Allied to $\mathrm{R}$. albiscapa, but wants the black breast-band.

Hab. : 2, 8 .

136. R. rufifrons, Lath., Rufous Fan-tail.

Frontal plumes and eyebrows rufous; bases of central tail feathers rufous for nearly two-thirds their length ; fore-neck scaled in appearance, the feathers black, broadly edged with white; head and neck brown.

$$
\text { Hab. : 2, 3, 4, } 6 \text {. }
$$

137. R. dryas, Gld., Wood Fly-catcher.

Smaller than R. rufifrons, has more white in tips of tail, which is fringed with rufous at base only ; breast white, crossed by distinct band of black, and devoid of the dark spots on chest of R. rufifrons.

Total length, $5 \cdot 75$ in. ; wing, $2 \cdot 6$ in. ; tail, $3 \cdot 5$ in.

$$
\text { Hab. : 1, } 2 .
$$

138. R. setosa, Quoy and Gaim., Northern Fan-tail.

Adult Male--General colour dark ashy-grey; head and sides of face blackish ; tail blackish, penultimate feathers slightly tipped with white; malar line and throat white; broad band of ashy-grey across fore-neck and chest, some feathers with whitish shaft lines; centre of body light buff, fading into white on under tail coverts.

Female similar.

Total length, 7 in. ; culmen, 0.6 in. ; wing, 3.5 in. ; tail, 3.6 in. ; tarsus, 0.6 in.

Hab. : 1, 2, 8. 
139. R. tricolor, Vieill. (Sauloprocta motacilloides, Vig. and Hors. ; R. picata, Gld.), Black and White Fan-tail.

Tail feathers entirely black; no spots on fore-neck or sides of neck ; upper surface and throat jet black ; abdomen white. Hab. : 2, 3, 4, 7, 8, 9 .

140. R. diemenensis, Dusky Fan-tail.

Resembles R. albiscapa ; insular form.

Ramsay's Tab. List, p. 6.

Hab. : 5.

141. R. phasiana, De Vis, Pheasant Fan-tail.

Wings distinctly spotted.

Hab. : 2.

142. R. dahli (doubtful sp.)

New Pomerania Ornith., No. 5, p. 7. Hab. : 1.

Gexus-MYIAGRA.-Wing longer than tail; bill arched, moderately broad; when measured at base of forehead equal to hind toe (without claw).

143. M. rubecula, Lath. (M. plumbea), Leaden Fly-catcher.

Male.--Throat leaden-grey, like head; abdomen white; back leaden-grey ; lores lead colour, not darker than sides of face. Wing, $3 \cdot 1$ in. ; tail, $2 \cdot 8$ in.

Female. -Throat light orange-rufous. Wing, $2 \cdot 8$ in. ; tail, $2 \cdot 6$ in. Above bluish-grey; wing coverts and quills brown, edged with bluish-grey; forehead and lores hoary; feathers below eye slate colour ; cheeks and fore-neck orange-rufous, paler on breast ; rest of under surface white.

Hab. : 1, 2, 3, 4, 5, 8.

144. M. nitida, Gld., Satin Fly-catcher.

Male.-Throat greenish-black; abdomen white; back glossy green; lores and ear coverts blacker. Wing, 3.5 in.; tail, 3.25 in.

Female.-Wing, $3 \cdot 3$ in.; tail, $3 \cdot 1$ in.

Adult Female. - General colour above brown, shaded with slaty. grey; wing coverts black; tail brown, with pale shafts; head darker slate than back, and glossed with steel ; back, cheeks, throat, and fore-neck orange-rufous; rest of under surface white, washed with orange-buff.

$$
\text { Hab. : 2, 3, 4, 5, (7). }
$$

145. M. concinna, Gld., Blue Fly.catcher.

Male.-Thruat leaden-grey; abdomen white; back leaden-grey;

lores and feathers in front of eye black.

Female.-Throat light orange-rufous.

Wing, 3 in. ; tail, $2 \cdot 75$ in.

$$
\text { Hab. : 1, 2, 3, } 8 \text {. }
$$

146. M. latirostris, Gld., Broad-billed Fly-catcher.

Upper surface metallic dark green.

Male.-Throat light orange-rufous up to base of bill.

Female.-Much paler everywhere.

Hab. : $1,7,8$.

GENUS-MACHARORHYNCHUS.-Wing longer than tail; bill extremely broad and flattened on both mandibles, measured at base of forehead exceeds length of hind toe (without claw) ; culmen elevated into a distinct ridge.

147. M. flaviventer, Gld., Yellow-breasted Fly-catcher.

General colour above olive.green, yellow on rump; forehead and eyebrow bright yellow; feathers in front of and below eye black; 
ear coverts black ; chin and upper part of throat white; breast, abdomen, and under tail coverts bright yellow.

Total length, 4.6 in. ; culmen, 0.6 in. ; wing, $2 \cdot 2$ in. ; tail, 2 in. ; tarsus, 0.5 in.

Hab. : 2.

GenuS-SISURA. - Wing longer than tail ; bill narrower, measured across nostrils less than hind toe and claw; bill long and thin; culmen, 0.8 in.

148. S. inquieta. Lath., Restless Fly-catcher.

Under surface white, sometimes a rufous tint on breast; upper surface shining blackish-blue.

Total length, 8 in. ; culmen, 0.8 in. ; wing, 3.9 ; tail, 3.75 in.

Hab. : 2, 3, 4, 6, 7, 9.

149. S. nana. Gld., Little Fly.catcher.

'Total length, 6 in. ; culmen, 0.75 in. ; wing, 3.75 in. ; tail, 3 in.

Head glossy greenish-black; back and tail same but lighter; wings brownish-black; under surface white, tinged with buff on chest. - Gould.

Hab. : $1,7,8$.

Genus-ARSES. - Wing longer than tail; bill, when measured across nostrils, less than hind toe; bill stouter than Sisura; culmen, 0.6 in. Has a fleshy eye-wattle.

150. A. Iorealis, De Vis, Frill-necked Fly-catcher.

Similar to A. kaupi ; lores white.

Male.-Whole under surface white.

Female.-Ochreous band across lower throat.

Hab. : 2.

151. A. kaupi, Gld., Pied Fly-catcher.

Total length, 6 in. ; culmen, 0.5 in. ; wing, $3 \cdot 1$ in ; tail, 3 in.

Crown of head, ear coverts, broad crescent across back, and broad band across chest deep shining bluish-black; wings and tail brownish-black; throat and band across back of neck white; lower part of back and abdomen white.-Gould.

Hab. : 1, 2.

GENUS-PIEZORHYNCHUS.-Wing longer than tail ; plumage of head velvety, with soft scale-like plumes on crown of head and throat.

152. P. nitidus, Gld., Shining Fly-catcher.

Male.-Whole of plumage rich deep glossy greenish-black ; irides red.

Total length, $7 \cdot 3$ in. ; bill, 0.7 in. ; wing, 3.5 in. ; tail, 3.2 in.

Female.-Top and sides of head and back of neck rich deep glossy greenish-black ; rest of upper surface, wings, and tail rustybrown; whole under surface white.

Hab. : 1, 2.

153. P. gouldi, Gld., Spectacled Fly.catcher.

General colour above ashy-grey; upper tail coverts and tail feathers black, three outermost tipped with white; forehead and lores black, as also the plumes at angle of mouth and the chin and centre of throat ; hinder part of cheeks, sides of throat, fore-neck, and chest bright orange-rufous; centre of breast, abdomen, and under throat coverts white.

Total length, 5.8 in.; bill, 0.5 in.; wing, 2.9 in. ; tail, 2.8 in.; tarsus, $0 \cdot 7$ in.

Hab. : 2, 3, 4. 
154. P. leucotis. White-eared Fly-catcher.

Crown of head, back of neck, primaries, and six middle tail feathers black ; three lateral tail feathers black, with white tips; lores, broad mark over eye, ear coverts, sides of neck, scapularies, and upper tail coverts white; throat white, bounded below with black, the feathers lengthened and protuberant; chest and abdomen light grey.

Total length, 5.75 in. ; bill, 0.6 in. ; wing, 2.75 in.; tail, $2 \cdot 75$ in. ; tarsus, $0 \cdot 6$ in.

Hab.: 2, (4).

155. P. albiventris, Gld.

Dr. Sharpe includes this with P. gouldi. but Dr. Ramsay and others consider it distinct. See P.L.S. of N.S.W., 2nd series, vol. i., p. 1,144.

Hab. : 1, 2.

GENUS-MONARCHA.-Nostrils rounded and exposed.

156. M. melanopsis, Vieill., Black-faced Fly-catcher (Carinated Flycatcher).

Tail and wings not perceptibly darker than upper surface; quills dusky.brown edged with grey, like back; forehead, lores, and throat black; sides of neck and chest light grey, rest of under surface rufous.

Total length, $6 \cdot 75$ in.; bill, $0 \cdot 75$ in. ; wing, $3 \cdot 25$ in.; tail, 3 in.

In adult female forehead and throat are entirely grey, with a whitish shade before eye and at angle of mouth.

Hab. : 2, 4.

157. M. canescens. Salvad., Pearly Fly-catcher.

Tail and wings black, in strong contrast to back; quills black, without grey edging.

Hab. : 2.

\section{FAMILY-TURDIDA.}

Pill slender but rather wide and depressed; wing long and flat, with a very small bastard primary, not more than half the length of the second, the latter generally longer than the secondaries. Composed of birds generally migratory.

\section{SUB-FAMILY-SyLvinNe.}

Young in first plumage similar to adult.

Genus-ACROCEPHALUS.-Bastard primary is so minute that in adult birds it does not usually extend as far as primary coverts. In young birds it is usually somewhat larger. Bill is typically large, depressed and broad at base, with moderately developed rictal bristles.

158. A. longirostris, Gld. (Calamoherpe longirostris), Long-billed Reed-Warbler.

General colour of upper parts russet brown. Wing, 3 in. to 2.9 in ; tail, $2 \cdot 9$ in. to $2 \cdot 6$ in.; culmen, 0.8 in. Third primary longest ; second equal to or longer than sixth.

Hab. : 8, 9.

159. A. australis. Gld. (Calamoherpe australis), Reed-Warbler.

General colour of upper parts olive-brown. Wing, 3 in. to 2.7 in. ; tail, $2 \cdot 8$ in. to $2 \cdot 5$ in.; culmen, $0 \cdot 75$ in. Second primary between fifth and seventh.

Hab. : 2, 3, 4, 5, 6, 7 . 


\section{SUB-FAMily-TURdin.}

Young in first plumage differs from adult and has under parts spotted. Genus-GEOCICHLA (sub-gen. Oreocincla).-In Oreocincla feathers of head and back have a transverse terminal black band in strong contrast to brown general colour of upper parts. Axillaries are particuloured - basal half white, rest dark; bastard primary rarely exceeds 1 in. in length.

160. G. Iunulata, Lath., Mountain-Thrush.

Under surface lunated; general colour of upper parts dark olivebrown; subterminal spots on head and back obsolete; outside tail feathers with obscurely defined white tips ; culmen $1 \cdot 2$ in.

Hab. : 3, 4.

161. G. macrorhyncha, Gld., Large-billed Ground-Thrush.

Under surface lunated; general colour of upper parts russet brown; subterminal spots on head brown; basal part of inside web of secondaries and of many primaries buff; culmen 1.2 in. ; outside tail feathers with obscurely defined white tips.

Hab. : 5.

162. G. heinii, Cabani, Russet-tailed Ground-Thrush.

Under surface lunated; outside tail feather on each side tipped white on inner web for an inch or more; culmen $1 \cdot 1$ in.

Hab. : 2, (4).

163. G. cuneata, De Vis, Broadbent Ground-Thrush.

Under surface lunated; under tail coverts ochreous; outermost tail feather peculiarly coloured; fourth primary very long.

Hab. : 2.

\section{FAMILY-TIMELIID必.}

Bill very similar to that of the Thrushes and Warblers (Turdidæ); wings rounded and short, concave, so as to fit close to the body. Birds generally of limited migration.

Sub-Family - Ptilonorhynchine : Bower-Birds.

Their habits seem to assimilate them with Ground-Thrushes and Babblers (Dr. R. B. Sharpe).

Genus-PTILONORHYNCHUS. - Bill higher than broad at nostrils, with a lateral subterminal notch on upper mandible; nostrils entirely covered with silky feathers, dense and recurved.

164. P. violaceus. Vieill., Satin Bower-bird.

Male, general colour purplish-black; female, uppermost surface greyish-green, under surface lunated.

Total length, 12.5 in. ; culmen, 1.4 in. ; wing, 6.6 in. ; tail, 4.5 in.; tarsus, $2 \cdot 15$ in.

Hab. : 2, 3, 4 .

GENUS-AELURCEDUS.-Bill higher than broad at nostrils, with a lateral subterminal notch; nostrils not completely hidden, but overhung by scanty plumes; bill very stout, its depth at nostrils equal to length of inner toe (without claw).

165. A. maculosus, Ramsay, Spotted Cat-bird.

Crown of head ochreous-brown mottled; ear coverts black; tail feathers white tips; general colour above green.

Hab. : 2.

166. A. viridis, Lath., Cat-bird.

Crown of head uniform green; ear coverts green, mottled with dusky black; tail feathers tipped with white.

Hab. : 3, 4. 
GExus-CHLAMYDODERA - With a lateral subterminal notch on upper mandible ; nostrils not completely hidden; bill longer and thinner than preceding genus, its depth at nostrils much less than inner toe.

167. C. maculata, Gld., Spotted Bower-bird.

Male.-Band of bright lilac feathers on nape; upper surface mottled all over with reddish spots or bars at tips of feathers; throat and sides of body with spots or bars of brown; head rufousbrown, slightly varied with spots.

Female.-No lilac band; flanks barred with dusky; throat light reddish or tawny, slightly varied with dusky-brown crossbars and edges to feathers.

Hab.: 2, 3, 6, 7 .

165. C. guttata. Gld., Yellow-spotted Bower-bird. lata.

Male.-Head silvery-brown instead of rufous-brown of C. mácu-

Female.-Differs from C. maculata in having throat fulvescent, closely mottled with blackish centres and margins to feathers.

Hab. : 1, 7, 9.

169. C. nuchalis, Jardine and Selby, Great Bower-bird.

Male. - Band of bright lilac on nape; upper surface mottled with ashy-whitish or white tips or bars at ends of feathers; throat and sides of body perfectly uniform ; head uniform.

Female.-No lilac band; flanks perfectly uniform, or with obsolete bars of dusky; under tail coverts whitish, with narrow bars of dusky-brown; head uniform.

$\mathrm{Hab}: 1,8,9$.

170. C. orientalis, Gld., Queensland Bower-bird.

Male.-Band of bright lilac on nape ; head mottled with silverywhite tips to feathers, instead of being uniform, as in C. nuchalis.

Female.-Distinguished from female C. nuchalis by having head mottled with silvery-whitish tips to feathers. (Age may effect this.) Very closely allied to C. nuchalis.

Hab. : 2.

171. C. cerviniventris, Gld., Fawn-breasted Bower-bird.

No band of bright lilac on nape; flanks uniform; under tail coverts fawn colour, like breast; throat pale, longitudinally streaked with dusky; head and hind-neck uniform; back minutely spotted or streaked with white.

Hab. : 2.

GExUS-SCENOPAUS.-Bill higher than broad at nostrils, with a distinct festoon in upper mandible, formed by two notches on edge.

172. S. dentirostris. Ramsay, Tooth-billed Bower-bird.

General colour above dark olive-brown; ear coverts dusky-brown, streaked with reddish-brown; the sides of neck similarly streaked with broader streaks; under surface of body fulvous, having a streaked appearance.

Total length, 10.5 in.; bill, $1 \cdot 1$ in. ; wing, 5.6 in. ; tail, 3.7 in. ; tarsus, $1 \cdot 3$ in.

Hab. : 2.

GENos-SERICULUS.-Bill at nostrils as high as it is broad.

173. S. melinus, Lath., Regent-bird.

Adult Male.-Head, neck, and upper mantle of a velvety texture and brilliant orange-yellow, rest of mantle and entire back black; under surface of body black.

Adult Female. - General colour above brown, mottled with white centres to feathers, edged with black; hinder crown and occiput 
black; chin and sides of throat light reddish, with the centre and lower part of throat black; rest of under surface of body whitybrown.

$$
\text { Hab. : 3, (4). }
$$

\section{Sub-Family-Timeline (Proper).}

Tarsi long, exceeding the length of bill measured from the gape; rictal bristles distinct, though varying in number.

\section{Group-Bradypteri.}

Aberrant Reed-Warblers; through Megalurus and Sphenceacus they approach the Grass-Warblers, and Cisticolre especially.

Genus-STIPITURUS.-Tail much longer than body.

174. S. malachurus, Lath., Emu Wren.

- Tail of emu-like feathers; head light rufous, broadly striped with black towards the nape. Female.-Throat rufous.

'Total length, 6.2 in.; culmen, 0.4 in. ; wing, 1.55 in. ; tail, 4.4 in. ; tarsus, 0.7 in. Hab. : 3, 4, 5, 9.

175. S. ruficeps, Campbell, Lesser Emu Wren.

Tail of emu-like feathers; forehead and crown rufous-brown.

Total length, 3.9 in. ; wing, 1.4 in. ; tail, 1.95 in.; bill, 0.3 in. ; tarsus, .55 in.

Hab. : 8.

GENUS-SPHENURA.-Has three stout rictal bristles.

176. S. brachyptera, Lath., Bristle-bird.

Head brown, upper surface uniform reddish-brown; under surface of body dull white. Wing, $3 \cdot 1 \mathrm{in}$. Hab. : 3, 4.

177. S. Jongirostris, Gld., Long-billed Bristle-bird.

Head brown; head and back mottled; under surface grey to brown; wing, 25 in.

Hab. : 9.

178. S. broadbenti, M'Coy, Rufous Bristle-bird.

Head rufous ; under surface rufous and barred.

Hab. : 4.

Gents-AMYTIS.-Ten tail feathers, ordinary and soft; shafts elastic but not spiny ; rictal bristles five in number, and not recurved.

179. A. textilis, Quoy and Gaim., Grass.Wren.

Brownish, much streaked; chest striated; no black stripe along cheeks ; wing $2 \cdot 3$ in.

Hab. : $6,7,9$.

180. A. striata, Gld., Striated Grass-Wren.

Chest striated; has a broad black cheek-stripe; upper plumage more rufous.

Hab. : 6, 7, 9.

181. A. macrura, Gld., Large-tailed Grass-Wren.

Brownish, much streaked; chest striated; no black stripe along cheeks; wing, $2 \cdot 5$ in. The specific difference, if any, between this' and textilis is very slight.

Hab. : 7, 9.

182. A. goyderi, Gld., Goyder Grass-Wren.

Brownish, much streaked; chest uniform white, like throat.

Hab. : 7. 
GendS-MEGALURUS.-Twelve tail feathers; tail longer than wing.

183. M. gramineus, Gld. (Sphenœacus gramineus), Grass-bird.

Back brown; secondaries black, edged buff; fore-neck and lower

throat more or less distinctly streaked with dark brown.

Total length, 5.75 in.; bill, 0.5 in.; wing, 2.3 in.; tail, 2.5 in. Hab. : $3,4,7,9$.

184. M. galactotes, Temm. (S. galactotes), Tawny Grass-bird.

Back brown and black ; fore-neck and lower throat not spotted or streaked; head more rufescent.

Total length, 6.5 in. ; culmen, 0.6 in. ; wing, 2.6 in. ; tail, $3 \cdot 3$ in. Hab. : $1,2,3,4,6,7$.

GEvos-ORIGMA. - Twelve tail feathers; wing much longer than tail.

185. O. rubricata. Lath., Rock-Warbler.

General colour above sooty.brown; upper tail coverts and tail feathers blackish, with narrow pale margius to tips of latter; head like back, the frontal plumes pale rufous, tipped with dusky brown ; throat ashy whitish, mottled with dusky bases; rest of under surface deep ferruginous.

Total length, $5 \cdot 75$ in. ; culmen, 0.6 in. ; wing, $2 \cdot 6$ in. ; tail, 2.4 in. Hab. : 3, 4.

\section{Group-Cisticolæ: Grass-Warblers.}

The Acanthizæ and Sericornes weaken the unity of this group because of their likeness to the foreign Willow.Warblers (Phylloscopi). Sharpe.

Gevus-CISTICOLA. - Tail strongly graduated or rounded.

186. C. exilis, Vig. and Hors. (including also C. ruficeps, C. lineocapilla, and C. isura), Grass-Warbler.

Sandy buff, much striped.

According to Dr. R. Bowdler-Sharpe, C. ruficeps (Rufous-headed Grass.Warbler), C. lineocapilla (Lineated Grass.Warbler), and C. isura (Square-tailed Grass-Warbler) are seasonal and sex variations of C. exilis. "In Australia the full-plumaged males have rufous heads, the females striped heads, and the winter plumage of both sexes appears to be blackish, with streaked backs and heads. C. ruficeps is adult male; $\mathrm{C}$. exilis is the bird in full winter plumage, while $C$. isura is only the square-tailed summer-plumaged birds."

C. magna, Gld. In Ramsay's List as found in New south Wales, but marked doubtful. No specimen in Australian Museum.

Hab. : $1,2,3,4,5,8$.

Genos-CHTHONICOLA.-Tail quite even; tarsus scutellated ; first primary long-half length of whole wing.

187. C. sagittata, Lath., Little Field-Wren.

Plumage olive-brown; throat and under surface very pale yel. lowish, with broad black streaks, broader on breast and sides; under tail coverts uniform yellow.

Hab. : 3, 4.

GeNos-ACANTHIZA.--Tail quite even ; tarsus scutellated ; first primary narrow and short-half length of second primary.

188. A. nana, Vig. and Hors., Little Tit.

Band on tail strictly subterminal ; throat rufescent, streaked with whitish shaft lines; upper surface uniform olive-green.

Hab. : 3, 6 . 
189. A. inornata, Gld., Plain-coloured Tit.

(a) Band on tail subterminal. (b) Throat ashy-white or yellowishwhite. (c) Head like back, except scaly feathers on forehead. No perceptible dusky streaks on throat and breast, which are plain whitish; upper tail coverts dingy olive-brown, but not strikingly different from back.

Hab. : 4, 6, 9.

190. A. pusilla, Lath., Brown Tit.

(a) Band on tail subterminal. (b) Throat ashy-white. (c) Head like back, except scaly feathers on forehead. (d) Throat and breast perceptibly streaked with dusky-black ; upper tail coverts reddish, contrasting with upper parts of body. (e) No white tips to tail feathers ; forehead pale rufous, with dusky-brown tips to feathers. ( $f$ ) Smaller than diemenensis; colour about light olive-greenish; abdomen pale yellow; flanks light fulvous brown. Wing, 2 in.; tail, $1 \cdot 75$ in.

Hab. : 3, 4.

191. A. diemenensis, Gld., Brown-rumped Tit (Tasmanian Acanthiza). Like A. pusilla in $(a),(b),(c),(d)$, (e), but larger (wing, $2 \cdot 1$ ), and colour above is yellowish-white, flanks olive-brown.

Hab. : 5 .

192. A. apicalis, Gld., Broad-tailed Tit (Western Acanthiza).

Resembles A pusilla in $(a),(b),(c),(d)$, but tail feathers have distinct white tips to inner webs, and upper tail coverts are rufousbrown; frontal feathers black, with whitish margins. Hab. : 7, 9.

193. A. py rrhopygia, Gld., Red-rumped Tit.

Resembles A. pusilla in $(a),(b),(c),(d)$, but tail feathers have distinct white tips to inner webs, and upper tail coverts are bright rufous; forehead pale rufous, with dusky margins to feathers. Hab. : 6, 7 .

194. A. lineata, Gld., Striated Tit.

Band on tail strictly subterminal, and not equal to basal half of tail; throat ashy-white; head a little more rufescent brown than back, and streaked conspicuously with whitish shaft lines; back olive-greenish.

$$
\text { Hab. : 3, 4, } 6 .
$$

195. A. uropygialis, Gld., Chestnut-rumped Tit.

Dark band on tail, occupying nearly terminal half of feathers; base of tail bright rufous, like upper tail coverts.

Hab. : 6,7 .

196. A. chrysorrhoa, Quoy and Gaim. (Geobasileus chrysorrhœa), Yellow-rumped Tit.

Dark band on tail, occupying nearly terminal half of feathers; base of tail bright yellow, like upper tail coverts.

Hab. : $2,3,4,5,6,7,9$.

197. A. reguloides, Vig. and Hors. (Geobasileus reguloides), Buffrumped 'Tit

Dark band on tail, occupying nearly terminal half of feathers; base of tail pale fulvous-brown; upper tail coverts dull yellow.

Total length, 3.9 in. ; culmen, 0.4 in. ; wing, 1.95 in.; tail, 1.45 in.; tarsus, 0.65 in.

Hab. : 3, 4, 6, 7.

198. A. Squamata, De Vis, Scaly-breasted Tit.

Similar to A. reguloides. It is larger, and has a shorter tarsus.

Hab. : 2. 
Genos-SERICORNIS.-Upper surface sombre; plumage silky; tail quite even ; tarsus plain.

199. S. brunnea, Gld. (Pyrrholæmus brunneus), Red-throat.

Tail feathers with no distinct subterminal band; tail feathers broadly tipped with white; throat bright rufous. [Female has throat whitish. - North.]

Hab. : 6, 7, 9.

200. S. citreogularis, Gld., Yellow-throated Scrub-Wren.

Tail feathers with no distinct subterminal band; no white tips to tail feathers ; throat bright yellow ; lores and ear coverts black ; no white tips to bastard wing feathers or wing coverts.

Hab. : $2,3,4$.

201. S. frontalis. Vig. and Hors. (S. gularis: British Museum Catalogue includes S. minimus, Gld.), White-browed Scrub-Wren (White-fronted Sericornis).

Tail feathers with no distinct subterminal band; no white tips to tail feathers; throat white, with blackish spots or edgings 10 feathers; wing coverts black, tipped white; a white spot over lores; under tail coverts pale yellowish.

Hab. : 3, 4, 6, 7 .

202. S. minimus, Gld., Little Scrub.Wren.

British Museum Catalogue considers this synonymous with S. frontalis. It has a longer wing.

Gould, "Birds of New Guinea," part i., pl. 13.

Hab. : 1, 2.

203. S. magnirostis, Gld., Large-billed Scrub-Wren.

Tail feathers with no distinct subterminal band; no white tips to tail ; throat, lores, and base of forehead pale tawny fulvous.

Hab.: 2, 3, 4 .

204. S. laevigastra, Gld. (S. lævigaster), Buff-breasted Scrub-Wren.

Tail feathers with dark subterminal band, with white edging to tip of outer tail feathers; inner secondaries not edged white; base of forehead black; ear coverts blackish; throat white and fore-neck yellow, with scarcely any spots; under tail coverts uniform yellow. Hab. : $1,3$.

205. S. maculata, Gld., Spotted Scrub-Wren.

Tail feathers with dark subterminal band, with white edging to tips of outer feathers; inner secondaries not edged white; base of forehead brown, like head; throat and chest very thickly spotted with blackish; under tail coverts yellowish with concealed darker centres.

Hab. : 4, 7, 9.

206. S. magna, Gld. (Acanthornis, Legge), Scrub-Tit.

Tail feathers with distmct subterminal band, and with white edging to tips of outer ones; inner secondaries narrowly edged and tipped with white; under tail coverts brown with yellow edges.

Hab. : 5.

207. S. osculans, Gld., Allied Scrub-Wren.

Tail feathers with dark subterminal band, but with no white edge to tip of outer ones; breast uniform; throat streaked with black; outer under tail coverts yellowish white with brown centres. Hab. : 4.

208. S. humilis, Gld., Brown Scrub-Wren.

Tail teathers with dark subterminal band, with no white edging to tips of tail feathers; the breast streaked dusky; throat with blackish streaks; under tail coverts uniform dark olive-brown, like flanks.

Hab. : 5. 
209. S. gutturalis, De Vis, Collared Scrub-Wren.

On the lower throat is a broad black crescentic band with its marginal feathers posteriorly edged with ashy-white.

Hab. : 2.

\section{Group-Crateropodes.}

True Babbling Thrushes, remarkable for strong, clumsy feet and powerful rounded wings.

The genera most out of place in this group seem to be Cinclo. rhamphus and Calamanthus.-Sharpe.

GENOS-ORTHONYX. - Shafts of tail feathers produced and stiffened.

210. D. Spinicauda, Temm., Spine-tailed Log-runner.

Under surface white; wing coverts tipped with grey; eyebrow and ear coverts grey. Male, throat white; female, throat orange-rufous. Hab. : 3, 4.

211. O. Spaldingi, Ramsay, Black-headed Log-runner.

Under surface white ; wing coverts blackish, without grey bars ;

Male, throat white ; female, throat orange-rufous.

Hab. : 2.

Genus-CINCLOSOMA. - Tarsus one-fourth the length of tail.

212. C. punctatum, Lath., Spotted Babbling-Thrush (Ground-Thrush).

Adult male, forehead and chest ashy-grey ; crown of head, back, rump, and middle tail feathers rufous-brown; each feather of back striped with black; shoulders and wing coverts steel black, each feather with white spot at tip ; throat and narrow band across chest steel-black. Female has throat greyish-white instead of black; spot on neck rufous instead of white, and has no black breast band. - Gould.

Hab. : $3,4,5,6,7$.

213. C. castanonotum. Gld., Chestnut-backed Babbling - Thrush (Ground-Thrush).

Adult Male.-Crown of head, back of neck, upper part of back, upper tail coverts, and two central tail feathers brown; stripe over eye and another from base of lower mandible down side of neck white; scapulars and lower part of back rich chestnut; shoulders and wing coverts black, each feather with white spot at tip ; chin, throat, and centre of breast steel black.

Female plumage much lighter, only a tinge of chestnut on rump ; chin, throat, and breast grey instead of black. - Gould.

Hab. : 6, 7, 9 .

214. C. cinnamomeum, Gld., Cinnamon Babbling-Thrush (GroundThrush).

Whole of upper surface, scapulars, two central tail feathers, sides of breast, and flanks cinnamon-brown; wing coverts jet black, each feather largely tipped with white; faint white eyebrow; lores and throat glossy black, with large oval patch of white within the black beneath eye ; under surface white, with large arrow-shaped patch of glossy black on breast.

Total length, $7 \cdot 5$ in. ; bill, 0.9 in.; wing, 3.75 in. ; tail, $3 \cdot 25$ in.

Female has no black markings on throat, breast, and wings, being brownish-grey instead. - Gould.

Hab. : 6, 7.

215: C. castaneothorax, Gld., Chestnut-breasted Babbling-Thrush (Ground-Thrush).

Crown of head, back of neck, and upper tail coverts rich brown, stripe over eye and another from base of lower mandible down side of neck white; shoulders and wing coverts black, with white spot at tip of each feather; all uppen surface, outer margins of scapulars and broad longitudinal stripe on their inner webs next shaft deep 
rust-red ; chin and throat black; chest crossed by a band of rich rust-red ; centre of abdomen white.

Total length, 8.5 in.; bill, 1 in. ; wing, 4 in.; tail, $4 \cdot 25$ in.; tarsus, 1 in.-Fould.

Hab. : 3,7 .

216. C. marginatum, Sharpe, Northern or Black-vented BabblingThrush (Ground-Thrush).

Similar to last species, but under tail coverts are black, margined with white, and washed with brown near base; breast band also is paler and more cinnamon-rufous, as are likewise flanks.

Hab. : 8.

Gexus-PYCNOPTILUS,-Tail quills very much graduated.

217. P. floccosus, Gld., Pilot-bird.

General colour above dark chocolate-brown; throat and breast rufescent ochre and mottled dusky; abdomen white; under tail coverts bright chestnut.

Total length, 6 in. ; culmen, 0.65 in. ; wing, 2.8 in. ; tail, 2.8 in. ; tarsus, 1.05 in.

Hab. : 4.

GENOS-DRYMAEEDUS. - Wing much graduated, third and fourth quills nearly equal.

218. D. brumneopygius, Gld. (Drymodes brunneopygia), Scrub-Robin.

Brownish; upper tail coverts rufous-brown; upper wing coverts brown, tipped with ashy whitish; a small black spot above and below eye.

$$
\text { Hab. : } 6,7,(9) \text {. }
$$

219. D. pallidus, Sharpe, Pale Scrub-Robin.

The supposed western variety of D. brunneopygius, Gld.

Underneath buffy-white, a little browner on the sides of the breast and flanks.

Hab. : 9.

220. D. superciliaris, Gld., Eastern Scrub-Robin.

Upper surface reddish-brown; under surface fawn; upper wing coverts black, broadly tipped with white; a distinct black spot above eye, as well as a vertical black streak across fore part of ear coverts.

$$
\text { Hab. : 1, } 2 .
$$

GENos-HYLACOLA.-Bill compressed, equally broad and high at base ; culmen gradually declining from base to tip, slightly notched at apex; rictus beset with a few fine hairs; nostrils basal, oblong; wings short, round, and concave ; first, second, and third primaries graduated; fourth, fifth, and sixth equal and longest; tail rather long and round; lateral toes equal.

221. I. pyrrhopygia, Vig. and Hors., Chestnut-rumped Ground-Wren. General colour above russet-brown; upper tail coverts light chestnut; wing coverts like back, the median and greater tipped with whitish; quills brown; tail feathers light reddish-brown, all but two centre feathers with distinct black bar and ends ashy-brown ; lores and a narrow eyebrow whitish; under surface of body dull whitish, thickly spotted with dusky brown on throat, breast, and sides of body ; under tail coverts bright chestnut, with white tips.

Total length, $5 \cdot 25$ in. ; bill, $0 \cdot 6$ in.; wing, $2 \cdot 1$ in. ; tail, $2 \cdot 5$ in. Hab. : 3, 6, 7, 9 .

222. H. cauta, Gld., Red-rumped Ground.Wren (Cautious Hylacola).

As compared with last species, the markings are much bolder on under surface, and chestnut-coloured mark. on rump is of a much deeper tint. 
Total length, $5 \cdot 75$ in. ; bill, 0.5 in.; wing, $2 \cdot 1$ in.; tail, 2.5 in. ; tarsus, 0.9 in.

Hab. : 4, 6.

GENCs-PSOPHODES.-Has large crest.

223. P. crepitans. Vig. and Hors., Coachwhip-bird.

Under surface of body black, with some white mottling on centre of breast; lateral feathers of tail tipped white ; lower flanks ashybrown.

Hab. : 2, 3, 4.

224. P. crepitans lateralis (sub-sp.), North.

Lateral feathers of tail tipped brown; lower flanks olive-green.

Hab. : 2.

225. P. nigrogularis, (Yld., Black-throated Coachwhip-bird.

Under surface of body greyish-brown; throat black.

Hab. : 9.

GeNus-POMATORHINUS.-Culmen long, and longer than tarsus.

226. P. temporalis, Vig. and Hors. (Pomatostomus temporalis), Babbler.

With a distinct white eyebrow ; throat and breast same colourwhite; no white wing bar; wing, $4 \cdot 6$ in.; lower breast rufous; forehead paler brown than nape.

Hab. : 1, 2, 3, 4, 6, 7 .

227. P. superciliosus, Vig. and Hors. (Pomatostomus superciliosus), White-browed Babbler.

With a distinct white eyebrow; no white wing bar; wing, 3.05 in. : lower breast whitish, without any rufous; forehead brown, like rest of crown.

Hab. : 1, 2, 3, 4, 6, 7, 9.

228. P. ruficeps, Vig: and Hors. (Pomatostomus ruficeps), Chestnutcrowned Babbler.

With a distinct white eyebrow ; throat and breast of same colour ; whitish tail feathers, broad white tips, with two white bars on wing ; head chestnut.

Hab. : 6, 7 .

229. P. rubeculus, Gld. (Pomatostomus rubeculus), Red-breasted Babbler.

With a distinct white eyebrow; throat white, but breast bright rufous.

Hab. : 1, (3), 7, 8.

GENUS-CINCLORHAMPHUS.-Inner secondaries nearly equal the primaries in length.

230. C. cruralis, Vig. and Hors. (C. cantillans), Brown Song-Lark.

R. B. Sharpe (1883) treats C. cruralis and C. cantillans as one species, the size of the abdominal patch appearing to vary according to amount of winter plumage remaining. "Birds with sooty-black under surface have bill black, and appear to be in breeding plumage."

Throat and belly blackish, upper tail coverts ashy-brown.

Hab. : 1, 2, 3, 4, 6, 7, 8 .

231. C. rufescens, Vig. and Hors. (Ptenœdus rufescens), Rufous SongLark.

Throat and belly whitish; upper tail coverts rufous.

Hab. : 1 to 4,6 to 9 .

GeNUS-CALAMANTHUS -Secondaries about equal.

232. C. fuliginosus, Vig. and Hors., Striated Field-Wren.

Head olive-greenish, streaked with black, like back; breast, sides of body, flanks, and under tail coverts streaked with black.

Hab. : 4, 5 . 
233. c. campestris, Gld., Field-Wren.

Head rufous, nearly uniform, or with narrow black streaks; breast pale yellow, distinctly streaked with dusky-brown; under tail coverts light rufous and brown, with white tips.

Hab. : 6, 9.

234. C. isabellinus (sub-sp.), North, Desert-Wren.

Horn Exp., Zool., p. 85.

Streaks on upper surface almost entirely lost. Hab. : 7.

The Vic. Nat., vol. xvi., No. 1, p. 3, refers to a C. rubiginosis, Campbell, which is probably this or the western form of the preceding species.

\section{Group-Accentores.}

Bearing a likeness to the Paridæ (Seebohm).

Grvos-EPHTHIANURA.-Bill slender, about equal in height and breadth at nostrils.

235. E. albifrons, Jardine and Selby, White-fronted Chat.

Male, black crescent across white breast ; throat white ; forehead white; hinder crown black. Female, greyer parts.

Hab. : 4, 6, 7, 9.

236. E. tricolor, Gld., Tricoloured Chat.

Throat white; forehead, crown, breast, and upper tail coverts crimson. Female, crown and breast faint red. Hab. : 2, 6, 7, 9 .

237. E. aurifrons, Gld., Orange-fronted Chat.

Throat black ; crown, breast, and rump orange or golden yellow. Female, head brown; under surface paler.

Hab. : 6, 7, 9 .

238. E. crocea, Castelnau and Ramsay, Yellow-breasted Chat.

Male, throat, upper tail coverts, and under surface of body bright yellow, with band of black across chest. Female less bright than male; no pectoral spot.

Hab. : $1,8$.

\section{FAMILY-PARID : Titmice.}

\section{Sub-FAMily-Parine.}

Bill without a notch; tarsus less than twice the length of the hallux without nail.

Guxus-XEROPHILA.-Bill higher than broad; nostrils in a semioperculated groove, round and partly hidden by feathers, first primary larger than half second ; tail square.

239. X. leucopsis, Gld., White-faced Titmouse.

Upper surface brown; forehead white ; under surface white, with no pectoral band.

Hab. : (2), 6, 7, 9.

240. X. pectoralis, Gld., Chestnut-breasted Titmouse.

Under surface whitish; has a pectoral band of cinnamon; brown above.

Hab. : 6.

241. X. nigricincta, North, Black-banded Titmouse.

Narrow black band on whitish breast; brown above.

Plate, Horn Exp., Zool.

Hab. : 7. 
Genus-SPHENOSTOMA.-Crested.

242. S. cristatum, Gld., Wedge-bill.

General colour above uniform earthy-brown; outer tail feathers dark brown, with large white tips; under parts dingy white, washed with greyish-brown; feathers of occiput prolonged into a long crest. Sexes alike.

Total length, 6.5 in.; bill, 0.5 in. ; wing, 3.2 in. to 3.4 in. Hab. : (1), 6, 7 .

\section{FAMILY-LANIID A:}

Insectivorous birds; bill strong, black or brown, notched and hooked; culmen curved or culmen straight with hardly any hook and notch, colour bluish-white; nostrils variable.

\section{SUB-FAMILY-GyMnORHININE.}

Nostrils placed almost midway between base and tip of bill, formed by a longitudinal slit, quite bare of feathers or bristles.

GEீNUS-GYMNORHINA.-Bill pointed and slightly hooked.

243. G. tibicen, Lath., Black-backed Magpie.

Black band across white back ; throat and breast black. Hab. : $3,6,7$.

244. G. leuconota, Gld., White-backed Magpie.

Whole of back pure white, like neck and rump; throat and breast

black. Female, back not pure white.

Young. - Whole of back clouded with grey.

Hab. : 4, 6, (8), (9).

245. G. dorsalis, Campbell, Long-billed Magpie.

Trans. Roy. Soc. Vic., 1895, p. 206.

Hab. : 9

246. G. Iyperlenca, Gld. (G. organicum), Lesser White-backed Magpie. The Tasmanian form of G. leuconota. It is not recognized in the British Museum Catalogue as a good species. In it the adult male has culmen $1 \cdot 7$ in. ; wing, $9 \cdot 3$ in.; tail, 5.75 in.

Hab. : 5.

Genos-CRACTICUS.-Bill strongly hooked.

217. C. quoyi, Less., Black Butcher-bird.

All black. Total length, $14 \cdot 5 \mathrm{in}$.

Hab. : 1, 2.

248. C. nigrigularis, Gld. (C. robustus, Lath.), Black-throated Butcher-bird.

Belly white; throat black ; centre of back black, separated from head by white collar; tail coverts covering less than half tail.

Total length, $13 \mathrm{in.}$; culmen; $1 \cdot 9$ in. ; wing, $7 \cdot 1$ in.

Hab. : $1,2,3,6,7,8$.

249. C. picatus, Gld. (sub-sp. of C. nigrigularis), Pied Butcher-bird.

Total length, 11 in. ; culmen, 1.5 in.; wing, 6.5 in. Hab. : $1,8$.

250. C. leucopterus, Gld., White-winged Butcher-bird.

Throat white; back bluish-grey; flanks brownish ; sides of upper breast grey, contrasting with head, which is deep black.

Hab. : 9.

251. C. argenteus, Gld., Silvery-backed Butcher-bird.

Belly white; throat white; flanks and sides of breast pure white, like rest of under surface ; back silvery-grey.

Hab. : 1. 
252. C. destructor, Temm. (C. torquatus, Lath.), Butcher-bird (Collared Crow-Shrike).

Throat white; back grey; flanks brownish; sides of upper breast brownish ; culmen, $1 \cdot 25$ to $1 \cdot 5$ in. Hab. : (2), 3, 4, 6, 7, 9.

253. C. cinereus, Gld. (sub-sp. of C. destructor, Temm.), Grey Butcherbird.

Has larger bill-1.45 in. Hab. : 5.

254. C. Spaldingi, Masters, Spalding Butcher-bird.

Like $\mathrm{C}$. quoyi : bases of all feathers above and below slaty-brown, and not dull white, as in C. quoyi (Masters). This is not recognized universally as a good species.

Hab. : 1 .

255. C. rufescens, De Vis, Rufous Butcher-bird.

Upper surface rufous; back streaked with buff and brown; crown of head to mantle black, streaked with tawny rufous ; under surface tawny buff; under tail coverts rufous.

Hab. : 2.

\section{SUB-FAMILX-PACHYCEPHALINE.}

Culmen curved downwards throughout its length, or the bill considerably flattened near its base; nostrils in a coriaceous groove, with an imperfect operculum.

GenUs-FALCUNCULUS.-Crested ; secondaries graduated.

256. F. frontatus. Lath, Yellow-bellied Shrike-Tit.

Under surface yellow; back olive-green. Male has throat black; female has throat green.

Hab. : 2, 3, 4, 6, 7 .

257. F. I eucogaster, Gld., White-bellied Shrike-Tit.

Very like F. frontatus, but has lower part of breast, whole abdomen, and flanks entirely white instead of yellow.

Hab. : 9.

Genus-OREOICA.-Crested.

258. D. cristata, Lewin, Bell-bird (Crested Oreoica).

Adult Male.-General colour above reddish-brown; head light grey, but forehead and lores white ; crest deep brownish-black; black stripe extends over cheeks and unites with black of lower throat; chin and upper part of throat white, enclosed by abovementioned black stripe ; lower part of throat. fore-neck, and upper part of breast deep brownish-black; lower breast and labdomen white.

Adult Female.-Lighter in colour, and has the lower throat and upper breast nearly uniform reddish-brown.

Total length, 8.4 in.; bill, 0.8 in ; wing, 4.1 in. ; tail, 3.5 in. ; tarsus, $1 \cdot 1$ in.

Hab. : 1, 2, 3, 6, 7, 8, 9.

GENUS-EOPSALTRIA.-Bill at nostrils broader than high.

259. E. australis, Lath., Yellow-breasted Shrike-Robin (Yellow Robin). Abdomen bright yellow, only upper throat whitish. Culmen, $0 \cdot 7$ in. Hab. : 3, 4.

260. E. magnirostris, Gld. (E. chrysorrhous), Yellow-rumped ShrikeRobin.

Gould, Ann. Mag. of N. H., iv., p. 109.

Rump and breast beautiful jonquil-yellow. Culmen larger than in $\mathbf{E}$. australis.

Hab. : 2, 3. 
261. E. georgiana, Quoy and Gaim., Grey-breasted Shrike-Robin.

Abdomen bright yellow; forehead and upper chest grey.

Hab. : 9.

262. E. pulverulenta, Bparte. (E. leucura, Gld.), White-tailed ShrikeRobin.

Under parts white; rest of plumage black; basal half of tail feathers white.

Hab. : $1,2$.

263. E. gularis, Quoy and Gaim., White-breasted Shrike-Robin (Whitebellied Robin).

Under parts white, rest of plumage black; tips of tail feathers white.

E. capito, Gld., and E. nana, Ramsay, are placed with Pœcilodryas, p. 15.

Hab. : 6, 9.

GENUS-PACHYCEPHALA.-Bill at nostrils equal in height and breadth.

264. P. melanura. Gld. (includes P. robusta), Black-tailed Thickhead. Under surface rich yellow; pectoral collar jet black ; above oliveyellow ; throat white ; head black ; tail black; breast gambogeyellow.

Female.-Below isabelline-yellow.

Hab. : $1,2,3$.

265. P. gutturalis, Lath., White-throated Thickhead (supposed to include P. rufogularis, A.A.A.S. Vernacular List, p. 10).

Male.-Under surface rich yellow; pectoral collar jet black ; throat white; head black ; only terminal part of tail black; basal part grey, washed with olive.

Female.-General colour above, head, neck, upper tail coverts and tail olive-brown; wing coverts and secondaries blackish-brown, edged with reddish-brown; primaries edged with grey ; throat pale brown, with white spots; under parts buff, without streaks; under wing coverts whitish.

Hab. : 2, 3, 4, 6 .

266. P. occidentalis, Ramsay, Western Thickhead.

Male.-Under surface rich yellow; pectoral collar jet black ; throat white; head black; only terminal part of tail black; basal part simply grey.

Female.-Lower part of chest, flanks, abdomen, and under tail coverts rufous-buff.

Hab. : 9.

267. P. peninsulae, Hartert, York Thickhead.

Male.-Crown ashy-brown, remainder of upper surface and tail olive-green; lores ashy; indistinct pale buffy eyebrow; throat white; breast light yellowish-grey, with darker shaft lines; abdomen pale sulphur-yellow, with dark shaft stripes; under wing coverts white, with faint yellow.

Hab. : 2.

268. P. glaucura, Gld., Grey-tailed Thickhead.

Male. - Under surface rich yellow ; pectoral collar jet black ; above olive-yellow ; throat white ; head black ; tail entirely grey.

Female.-Greyish.

Hab. : 5.

269. P. falcata, Gld., Northern Thickhead.

Male. - No trace of yellow in plumage; black pectoral collar ; general colour above ashy-grey; throat white; under surface creamy pale isabelline (brownish-yellow) ; collar broad.

Female.-Under surface fawn, with shafts streaked black.

Hab. : $1,8$. 
270. P. pallida, Ramsay, Pale-breasted Thickhead.

Male.-No trace of yellow; black pectoral collar; general colour above ashy-grey; throat white; under surface white, tinged with cream colour ; collar narrow.

Female.-Under surface creamy-white, each feather streaked with brown.

Hab. : 1, 2.

271. P. rufiventris, Lath. (P. pectoralis, Vig. and Hors.), Rufousbreasted Thick head.

No yellow in plumage; ashy-grey above; throat white; under surface orange-brown.

Adult female has upper parts like male but tinged with ashybrown ; lores and ear coverts ashy-brown ; throat and cheeks white, with dark brown streaks ; under parts light fawn, distinctly streaked on breast, but less so on abdomen, flanks, and under tail coverts. Hab. : 2, 3, 4, 6, 7, 9 .

272. P. rufogularis, Gld., Red-throated Thickhead.

No yellow in plumage; black pectoral collar; ashy-grey above; throat rusty-red ; head ashy-grey; under surface sandy-buff; chest washed with brownish-grey; lores and cheeks rusty-brown; under wing coverts greyish-buff in male, dull white in female.

Adult female differs in having throat and under surface greyishwhite (without rufous tinge); an obscure grey mark on chest; streaks down each feather.

Hab. : 6, 7.

273. P. gilberti, Gld., Gilbert Thickhead.

No yellow in plumage; black pectoral collar; above ashy grey ; throat rusty-red; head ashy-grey; under surface sandy-buff ; chest washed with brownish-grey; lores black ; under wing coverts sandybuff in both sexes.

Adult female has upper surface like male but wants black lores and rusty-red on throat, the throat and fore-neck being grey, gradually passing into buff of rest of under surface. Hab. : 6, 7, 9 .

274. P. olivacea, Vig. and Hors., Olive Thickhead.

No black pectoral collar; throat white, freckled with brown ; body below dull fawn; upper surface and tail olive-brown. Female like male, but has head olive-brown instead of greyish-brown, and is chestnut-olive instead of brownish-olive above.

$$
\text { Hab. : 4, } 5 \text {. }
$$

275. P. simplex, Gld., Brown Thickhead.

All upper surface uniform fuscous-brown; quills plain brown; lores and ear coverts paler ; chin, cheeks, and rest of under surface. white; under wing coverts, axillaries, and edge of wing white.

Total length, 5 in.; culmen, $0 \cdot 6$ in.; wing, 3 in.; tail, $2 \cdot 3$ in. Hab. : 1 .

276. P. Ianioides, Gld., White-bellied Thickhead.

Head and breast black; hind-neck with black collar, bordered with chestnut band; upper parts ashy; abdomen and throat white.

$$
\text { Hab. : } 8 .
$$

277. P. fretorum, De Vis, Torres Straits Thickhead.

\section{Similar to 276.}

Male, black and chestnut pectoral bands; the chestnut collar occupies the whole of the neck on its upper surface.

Young male wants the nuchal collar.

$$
\text { Hab. : } 2 .
$$




\section{Group-Certhiomorphæ.}

Angle of the chin reaching as far as the line of the anterior margin of the nasal suture, but not beyond it ; tongue not extensile; bill entire, not notched.

\section{FAMILY-CERTHIID $Æ$.}

Bill either straight and subulate or slender, long and curved; nostrils basal ; tail never emarginated ; fourth toe coalesced at first phalanx with the middle toe. Principally insectivorous. Breeding in holes.

\section{SUb-FAMILY-Certhiñ}

Nostrils basal, longitudinal, operculated, exposed; no nasal and rictal bristles. Insectivorous.

GENUS-CLIMACTERIS.-General colouration brown; tail square, soft, and shorter than wing; one plate on tarsus.

278. C. melanura, Gld., Black-tailed Tree-creeper.

Fawn-coloured band across wing; all upper parts uniform brownish-black ; throat black, with white lanceolate stripes. Hab. : 1, (6), 8.

279. C. melanonota, Gld., Black-backed Tree-creeper.

Fawn-coloured band across wing; all upper parts uniform brownish.black; throat dull white, without stripes.

Hab. : 1.

280. C. rufa, Gld., Rufous Tree-creeper.

Fawn-coloured band across wing; mantle brown; centre pair of tail feathers, lower back, and upper tail coverts olive-brown; under surface rusty-red; flanks without stripes.

Hab. : 8, 9.

281. C. Ieucophaea, Lath. (C. picumnus), White-throated Tree-creeper.

Throat white ; fawn-coloured band across wing; centre pair of tail feathers dark grey.

$$
\text { Hab. : 2, 3, 4, 6, } 7 \text {. }
$$

282. C. scandens, Temm., Brown Tree-creeper.

Fawn-coloured band across wing; central pair of tail feathers brown : orbital region brown; throat brownish or brownish-white. Hab. : 2, 3, 4, 6, 7 .

283. C. pyrrhonota, Gld., Red-backed Tree-creeper.

Fawn-coloured band across wing; centre pair of tail feathers dark brown; lower back and upper tail coverts rich rusty-red, distinguishing it from C. scandens. Male wants rusty patch to cheeks.

Hab. : 4, 5, 6 .

284. C. erythrops, Gld., Red-browed Tree-creeper.

Fawn-coloured band across wing; mantle brown; centre pair of tail feathers brownish in male, greyish in female; lower back and upper tail coverts ruddy grey; orbital ring rich rusty-red; dull buff crescent across upper chest.

Hab. : 3, 6, 7 .

285. C. superciliosa, North, White-browed Tree-creeper.

Plate, Horn Exp. Cent. Aust., Zool.

Similar to C. erythrops, with white superciliary band.

Hab. : 7, 9.

SUB-FAMILY-SiTTINE.

Bill straight and subulate, never toothed, but slightly notched; nostrils in a coriaceous groove; wing double the length of tail. Insectivorous. Breeds in holes. Transverse scales on tarsus. 
Gexos-SITTELLA. - Bill slightly curved upwards; nostrils with a cutaneous valve.

286. S. chrysoptera, Lath., Orange-winged Tree-runner.

Middle third of quills forming large rusty-red patch; breast and abdomen streaked with brown; crown of head dark brown.

Hab. : 2, 3, 4 .

287. S. leucocephala, Gld.. White-headed Tree-runner.

Middle third of quills forming rusty-red patch; breast and abdomen streaked with brown; head and neck all round white.

Hab. : 3, 7.

288. S. albata, Ramsay, Pied Tree-runner.

Middle third of quills pure white; head white all round.

Hab. : 2.

289. S. pileata, Gld., Black-capped Tree-1unner.

Middle third of quills forming large rusty-red patch ; breast and abdomen white, without any streaks; crown of head black.

[All upper part of head in female is black. Male has simply a black cap with white at base of bill and over eyes.-A. J. North.]

Hab. : 4, 6, 7, 9.

290. S. tenuirostris, Gld. (sub-sp. of S. pileata), Slender-billed Treerunner.

Middle third of quills forming rusty-red patch; breast and abdomen white, without any streaks; crown of head blackish-brown; middle third of quills half white and half rusty.

Hab. : 4,7 .

291. S. lencoptera, Gld., White-winged 'Tree-runner.

Middle third of quills pure white; head above black; breast and abdomen white, without streaks.

Hab. : 1, 8.

292. S. striata, Gld., Striated Tree-runner.

Middle third of quills pure white; head above black; breast and abdomen much streaked. Hab. : 1, 2, 3.

\section{Group-Cinnyrimorphæ.}

Angle of the chin reaching as far as the line of the anterior margin of the nasal suture, but not beyond it ; tongue extensile.

\section{FAMILY-NECTARINIID $\nexists$ E.}

Bill pointed, elongated, and curved; nostrils rounded, protected by a coriaceous membrane not hidden by bristles or feathers.

Genus-CINNYRIS.-Tail square; male with metallic colours.

293. C. frenata, S. Mïll. (sub-sp. of C. jugularis, Linn.), Sun-bird.

Male has crown of head and upper surface olive-green; over and under eye two inconspicuous marks of yellow; throat and chest steel-blue ; remainder of under surface fine yellow ; irides chestnut ; bill and feet black.

Total length, $4 \cdot 75$ in. ; bill, 0.9 in. ; wing, $2 \cdot 1$ in. ; tail, 1.5 in.

Female has whole of under surface yellow, without a trace of steel-blue gorget so conspicuous in male.

Hab.: 2. 


\section{FAMILY-MELIPHAGID $Æ$.}

Bill with prominent culmen and broadened out at base ; nostrils basal, situated in a large unossified groove; tongue bifid and brush-like.

\section{SUb-FAMily-Myzomeline.}

Small birds of the size of a sparrow. First primary about the length of the second.

Gexus-MYZOMELA.-Bill longer than rest of head, slender and curved. Tail two-thirds length of wing. Principal colours black and red. Female generally plain olive above.

294. M. sanguimolenta, Lath., Sanguineous Honey-eater.

Head red all round; middle line of back and rump red; chest and fore-neck red.

Female.-Brown; touch of red on rump.

Hab, : 2, 3, 4.

295. M. erythrocephala, Gld., Red-headed Honey-eater.

Head red all round; middle line of back black; rump red.

Female.-Uniform brown; lighter below.

Hab. : 1, 2.

296. M. nigra, Gld., Black Honey-eater.

Head and neck all round and mantle black; rest of back and tail blackish-brown; breast and abdomen pure white.

Female.-Upper surface brown; under surface brownish-white, centre of each feather being darker.

Hab. : $1,6,7,9$.

297. M. pectoralis, Gld., Banded Honey-eater.

Whole crown black; abdomen and breast white; upper tail coverts white; a pectoral crescent black.

Hab. : 1, 2, 8.

298. I. obscura, Gld., Dusky Honey-eater.

Upper and under parts olive-brown; crown slightly tinged with red.

Hab. : 1, 2, 3.

GENUS-ACANTHORHYNCHUS. - Tail about equal to wing in length.

299. A. tenuirostris, Lath. (including A. dubius), Spine-billed Honeyeater.

Crown black; a bronzy-brown crescent on chest separates the white throat, with a brownish patch upon it, from a reddish-fawn abdomen; no white eyebrow.

Culmen, 1.2 in.; wing, 2.5 in. ; tail, 2.3 in. ; tarsus, 0.70 in. Hab.: $3,4,5$.

300. A. superciliosus, Gld., White-browed Spine-bill.

Entire crown of head, mantle, and back greyish olive-brown, a streak behind eye and above ear coverts, chin, and cheeks, and a finely developed crescent across chest white; throat and neck all round chestnut-red; breast, abdomen, flanks, and under tail coverts pale buff, separated from white crescent by another one of brownishblack.

Hab. : (6), 9.

\section{SUB-FAMILY-ZOSTEROPINÆ.}

Bill shorter or equal to the rest of the head; a peculiar ring of short whitish feathers surrounds the eye. Plumage green, yellow, and white. 
GENUS-ZOSTEROPS.-First primary extremely short or wanting (except in the brown species).

301. Z. corulescens, Lath. (includes Z. westernensis, Quoy and Gaim. ; North), Silver eye.

Crown olive-green; back brown; under surface not uniform; throat white, sometimes tinged with olive.

Hab. : 2, 3, 4, 5, 6, 7 .

302. Z. ramsayi, Masters, Yellow-vented Silver-eye.

Crown of head, neck, throat, wings, rump, and under tail coverts greenish-yellow; lores and line beneath eye black; back and chest bluish-grey; abdomen light-grey, passing into buff on flanks; primaries and secondaries brownish-black, margined on outer webs with yellowish beneath, on inner webs with whitish; tail brown, margined with yellow.

H. Gadow considers it may be identical with $\mathrm{Z}$. westernensis.

Hab. : 2 (?).

303. Z. gouldi, Bparte., Green-backed Silver eye.

Head and rump of same tint as back, though sometimes brighter; throat olive-yellow; breast ashy-grey; sides of body clear rufous or pale chestnut.

Hab. : 9.

304. Z. albiventer, Reichenbach (includes Z. flavogularis, Masters), Pale-bellied silver-eye.

Head and rump of same tint as back, though sometimes brighter ; throat sulphur-yellow; breast pale ashy; sides of body pale ashygrey ; under tail coverts sulphur-yellow.

Hab. ; 1, 2.

305. Z. Intea, Gld., Yellow Silver-eye.

Throat yellow, like rest of under surface ; colour above grass-green. Bill, 0.5 in.

Hab. : 1, 2.

306. Z. gulliveri, Castelnau and Ramsay, Gulliver Silver-eye.

Colour above olive-yellow ; throat yellow, like rest of under surface. Bill nearly $0 \cdot 6$ in.

Hab. : 1.

GENUS-MELITHREPTUS. - Bill shorter than rest of head; operculum partly covered with feathers; first primary about third length of very long second primary ; tip of wing formed by third, fourth, and fifth; secondaries very short, two-thirds length of wing; tail slightly emarginate.

307. M. Iumulatus, Shaw (British Museum Catalogue includes M. chloropsis, Gld.), Lunulated Honey-eater.

Crown of head black; white band across occiput; chin pure white; under surface white; naked space above eye scarlet; wing, $2 \cdot 8$ in. to $3 \cdot 1$ in.

Hab. : 3, 4.

308. M. albigularis, Gld. (sub-sp. of M. lunulatus), White-throated Honey-eater.

Wing, $2 \cdot 6$ in. to $2 \cdot 8$ in.

Hab. : $1,2,3,8$.

309. M. chloropsis, Gld.

Similar to lunulatus; larger, and naked space above eye greenishwhite.

Hab. : 9. 
310. M. gularis, Gld., Black-chinned Honey-eater.

Crown of head black; white band across occiput; chin blackish ; under surface greyish-brown; culmen, 0.5 to 0.6 in. Hab. : 2, 3, 4, 9.

311. M. laetior, Gld., Golden-backed Honey-eater.

To be distinguished from gularis by white under surface, lemonyellow on back of neck, and yellow naked skin round eye. Hab. : 1, 2, 3, 6, 8 .

312. M. validirostris, Gld., Strong-billed Honey-eater.

Crown of head black; white band across occiput; chin blackish ; culmen 0.75 in.

Hab. : 5.

313. M. brevirostris, Vig. and Hors., Brown-headed Honey-eater (Short-billed Honey-eater).

Crown of head brownish, with cream-coloured band across occiput. Hab. : 2, 3, 4, 6, 7, 9.

314. M. melanocephalus, Gld., Black-headed Honey-eater.

Upper surface greyish-olive; under surface greyish-white ; crown of head black, with no white band across occiput.

Hab. : 5.

315. M. vinitinctus, De Vis, Gay Honey-eater.

Crown of head vinous-grey; white band across occiput.

'Total length, $4 \cdot 20$ in. ; wing, $2 \cdot 45$ in. ; culmen, $1 \cdot 5$ in.

Hab. : 2.

Gents-PLECTRORHYNCHUS.-Bill shorter than head and very straight.

316. P. lanceolatus, Gld., Striped Honey-eater.

Crown of head, sides of neck, and hind-neck greyish-white, with black mark down centre of each feather; cheeks aud all under parts pure white, except some feathers on sides of fore-neck, which are mottled black and white.

Young.-Throat dull wax-yellow; head brown and streaked.

Total length, 9 in. ; bill, 0.75 in. Wing, 4.7 in. male, $4 \cdot 4$ in. female.

Hab. : 2, 3, 6, 7 .

\section{SUb-FAMily-Meliphagine.}

The remaining genera of the Meliphagidæc constitute this sub-family.

Gends-GLYCYPHILA.-Bill a little longer than or equal to rest of head, broad at base; nostrils operculated, not covered with feathers; first primaries comparatively long; tip of wing formed by third to fifth primaries; secondaries three-fourths length of wing; tail square or slightly emarginated; inner web of quills fulvous. Tarsus covered with many transverse scales.

317. G. fulvifrons, Lewin, Tawny-crowned Honey-eater.

Sub-gen. Glycyphila.

Feathers behind eye of normal shape ; inner web of quills edged with fulvous; breast and abdomen white; throat white; forehead fulvous.

Hab. : 3, 4, 5, 6, 9.

318. G. albifrons, Gld., White-fronted Honey-eater.

Feathers behind eye of normal shape ; inner web of quills edged with fulvous; breast and abdomen white; throat blackish; forehead white.

Hab. : 6, $7,9$. 
319. G. fasciata, Gld., White-breasted Honey-eater.

Feathers behind eye of normal shape ; inner web of guills edged with fulvous; breast and abdomen white ; dark brown cross markings to feathers of chest.

Hab. : 1, 2, 3.

320. G. ocularis, Gld. (Stigmatops ocularis and subocularis), Brown Honey-eater.

Sub-gen. Stigmatops.-Feathers behind eye peculiarly shaped, being short, blackish at base, silky white or yellow at terminal half, giving post-ocular region a spotted appearance.

Wings not edged with white; ear coverts brown, upper parts uniform olive-brown; post-ocular feathers glossy yellow; under parts dingy brownish white or grey.

(A.A.A.S. Vernacular List Comm. says these are not the same.)

Subocularis = Least Honey-eater : Total length, 4.75 in.; culmen, 0.6 to 0.7 in. ; wing, 2.3 to 2.5 in. ; tail, 2 in. ; tarsus, 0.61 .)

Hab. : $\left\{\begin{array}{l}\text { ocularis, 1, 2, 3, 7, 8, } 9 . \\ \text { subocularis, } 1,2,8 .\end{array}\right.$

321. G. modesta, Gray, Brown-backed Honey-eater.

For characters of Stigmatops see last species.

Wings not edged with white; ear coverts brown; upper parts uniform olive-brown; a white subocular spot; under parts white, faintly barred with brownish.

Hab. : 2.

322. G. albiauricularis, Ramsay, Broadbent Honey-eater. For characters of Stigmatops see G. ocularis.

Wings not edged with white; ear coverts and subocular region with silvery-white spots.

Hab. : 2.

GeNos-ENTOMOPHILA.-Bill not longer than rest of head, broad at base; nostrils not beset with feathers, operculated; tip of wing formed by third and fourth primaries; tail square ; tarsus anteriorly scutellated.

323. E. albigularis, Gld., Rufous-breasted Honey-eater (Whitethroated Honey-eater).

Sub-gen. Conopophila.

Wings edged with wax-yellow; chest reddish-buff ; first primary about one-third length of second; secondaries five-sixths of whole wing; throat white.

Hab. : 1, 2, 8 .

324. E. picta, Gld., Painted Honey-eater.

Upper surface black; under surface white ; flanks spotted ; wings edged with wax-yellow; bill shorter than head; first primary extremely short, second about two-thirds length of wing.

Hab. : 6, 7.

325. E. rufigularis, Gld., Red-throated Honey-eater.

Sub-gen. Conopophila.

Wings edged with wax-yellow; bill shorter than head; first primary about one-third of wing; secondaries five-sixths of whole wing; throat reddish; general plumage brownish.

Hab. : 1, 2, 8.

326. E. leucomelas, Cuvier, Pied Honey-eater.

Sub-gen. Certhionyx.

Only colours black and white; first primary not so short as in foregoing sub-genera.

Hab. : $6,7,5,9$. 
Genos-MELIPHAGA. - Bright yellow and black.

327. M. phrygia, Lath. (Zanthomyza phrygia, Swainson), Warty-faced Honey-eater.

Bright yellow and black, much spotted and barred; head and neck black, except ocular region and cheeks, which are bare and warty.

$$
\text { Hab. : 2, 3, 4, 6, } 7 .
$$

GeNus-PTILOTIS. - Bill equal to or rather longer than rest of head; tip of wing formed by primaries $3,4,5$, and 6 ; secondaries between four-fifths and five-sixths length of wing; tail square or slightly rounded. Pattern of colour very plain, mostly olive above, dingy yellow below ; inner web of remiges invariably broadly margined with fulvous; parotid feathers often stiff and most frequently coloured yellow or white ; ear coverts always different colour from rest of head; no other colours than olive, yellow, white, and brown in plumage.

328. P. fusca, Gld., Fuscous Honey-eater.

Yellow colour confined to post-auricular feathers; upper parts olive ; ear coverts dusky olive-grey ; under parts dull yellowish-grey. Hab. : 2, 3, 4, 6, 7.

329. P. lewini, Swainson, Yellow-eared Honey-eater.

Yellow colour confined to post-auricular feathers; upper parts olive; ear coverts silky leaden-grey ; under parts ashy-olive.

Culmen, 0.8 in. ; wing, 3.6 in. ; tail, 3.4 in. ; tarsus, 0.8 in. Hab. : 2, 3, 4.

330. P. analoga, Gld. (P. notata), Yellow-spotted Honey-eater.

Doubtful species. This is said to be the northern variety of $P$. lewini, because of its slightly smaller size.

Ibis, 1898, p. 57.

Hab. : 1, 2.

331. P. gracilis, Gld., Lesser Yellow-spotted Honey-eater.

Much smaller than P. analoga, with proportionately longer bill ; otherwise the same.

Ibis, 1898, p. 57.

Hab. : 2.

332. P. frenata, Ramsay, Bridled Honey-eater.

Yellow feathers on sides of head forming conspicuous patch; ocular or auricular region bare.

Hab. : 2.

333. P. flavistriata, Gld., Yellow-streaked Honey-eater (Varied Honeyeater). Ramsay's Tab. List of Birds, p. 13, P. versicolor.

Yellow feathers on side of head form a conspicuous patch ; ocular or auricular region bare ; feathers on upper and hinder margin of ear golden yellow; ears bare, with a short wattle ; mantle spotted; breast striated.

Hab. : 1.

334. P. Sonora, Gld. (P. vittata, Cuvier), Singing Honey-eater.

With small white post-auricular patch; ear coverts yellow; black streak through eye; under parts with dull streaks; crown and mantle earthy-brown; upper half of ear coverts dark grey; under parts of body dingy yellow, with dull whitish streaks.

Hab. : 1, 2, 3, 4, 6, 7, 8, 9.

335. P. macleayana, Ramsay, Macleay Honey-eater.

Similar to $\mathbf{P}$. flavistriata.

No small white post-auricular patch; no black and yellow markings on the side of head.

Hab. : 2. 
336. P. chrysops, Lath., Yellow-faced Honey-eater.

With small white post-auricular patch ; ear coverts yellow ; black streak through eye; under parts with dull streaks; cheeks black; upper parts earthy-brown.

$$
\text { Hab. : 2, 3, } 4 .
$$

337. P. filigera, Gld., Streak-naped Honey-eater.

Yellow colour confined to post-auricular feathers; ocular and auricular region not bare ; upper parts brown ; ear coverts brownish ; a golden-yellow post-auricular stripe; under parts fulvous-brown. Hab.: 1,2

338. P. flavigularis, Gld. (P. flavicollis, Vieill.), Yellow-throated Honey-eater.

Throat gamboge-yellow; crown and fore-neck ashy-grey; mantle dark yellowish-olive.

Hab. : 4, 5 .

339. P. leucotis, Lath., White-eared Honey-eater.

Ear coverts pure white ; throat black ; crown ashy-grey. Hab. : 1, 3, 4, 6, 7, 8, 9 .

340. P. fasciogularis, Gld., Fasciated Honey-eater.

Bright yellow post-auricular tufts, followed by elongated feathers on sides of neck; throat ashy-brown, much barred with yellow; upper parts ashy-brown.

$$
\text { Hab. : 2, } 3 .
$$

341. P. cockerelli, Gld., Cockerell Honey-eater.

Post-auricular feathers forming decidedly elongated tufts (yellow); feathers of fore-neck hairy or lanceolate, white ; under parts dull white ; crown dark brown; median wing coverts tipped with white. Hab.: 2.

342. P. auricomis, Lath., Yellow-tufted Honey-eater.

Post-auricular feathers forming decidedly elongated yellow tufts ; feathers of throat not lanceolate; ear coverts and ocular region black; crown and under parts yellow; mantle olive-grey.

Hab. : $2,3,4,6,7$.

343. P. cassidix, Jardine, Helneted Honey-eater.

Post-auricular feathers forming elongated yellow tufts; feathers of throat not lanceolate ; ear coverts and ocular region black ; crown and under parts yellow; mantle blackish-brown.

Hab. : 4.

344. P. cratitia, Gld. (includes P. occiđentalis, Cabani), Wattle-cheeked Honey-eater.

Post-auricular feathers forming yellow tufts; under parts dull yellowish-white, without shaft streaks ; ear coverts not bounded by black stripe; crown grey; from gape down each side of throat a naked fleshy wattle of a beautiful lilac colour.

$$
\text { Hab. : 6, 8, } 9 \text {. }
$$

345. P. keartlandi, North, Keartland Honey-eater.

Plate, Horn Exp., Zool.

A line in front and the feathers above and below the eye blackish ; ear coverts silky-grey, slightly tipped with blackish-brown; conspicuous patch of light yellow feathers behind eye; cheeks, chin, throat, and all the upper surface pale lemon-yellow, slightly darker on centre of throat and fore-neck.

Hab. : 7, 8.

346. P. penicillata, Gld., White-plumed Honey-eater.

Post-auricular feathers forming decidedly elongated tufts (pure white) ; ear coverts dull yellow; upper parts dull earthy-brown. Hab. : 7 to 12. 
347. P. leilavalensis, North, Lesser White-plumed Honey-eater.

Records Aust. Mus., vol. iii., No. 5, p. 106.

Smaller than penicillata; more brightly coloured head; no black line between ear coverts and white. Like flavescens, except ear coverts.

$$
\text { Hab. : } 2 .
$$

348. P. ornata, Gld., Yellow-plumed Honey-eater (Graceful Honeyeater).

Post-auricular feathers forming elongated yellow tufts; ear coverts not black, but brownish; crown not yellow; under parts dull whitish, with broad brownish shaft streaks; mantle pale brownish-grey.

$$
\text { Hab. : 6, } 9 .
$$

349. P. plumula, Gld., Yellow-fronted Honey-eater (Plumed Honeyeater).

Post-auricular feathers forming elongated yellow tufts ; ear coverts not black, but yellowish-brown, with narrow black transverse stripe bounding yellow; under parts without shaft streaks and dingy yellowish-white; mantle pale olive-grey.

$$
\text { Hab. : 1, 6, 7, } 9 .
$$

350. P. flavescens, Gld., Yellow-tinted Honey-eater.

Post-auricular feathers forming elongated yellow tufts ; ear coverts yellowish-brown, with narrow black transverse stripe bounding yellow ; mantle pale olive-grey; under parts yellow, without shaft streaks.

Hab. : $1,8$.

350A. P. germana, Ramsay (sub-sp. of P. flavescens).

Size smaller; yellow stripe behind eye and black stripe beneath ear coverts more developed.

Hab. : 2.

351. P. flava, Gld., Yellow Honey-eater.

No pronounced yellow ear patches; all under parts rich yellow, including under surface of wing; upper parts rich greenish.yellow. Hab. : 1, 2.

352. P. unicolor, GId. (includes Stomiopera unicolor), White-gaped Honey-eater.

Auricular region without any yellow or white patches; plumage uniform dull brownish-grey.

Hab. : 1, 2, 8.

GENUS-MELIORNIS.-Bill about as long as rest of head; nostrils operculated, not covered by feathers ; first primary comparatively long; tip of wing formed by third to sixth ; quills internally edged with fulvous ; tail rounded.

353. M. australasiana, Shaw, Crescent Honey-eater (Tasmanian Honey-eater).

Male. - Crescent on whitish breast; narrow stripe above eye; quills partly golden yellow; mantle uniform ashy-grey.

Female.-No white eyebrow and crescent.

Hab. : 3, 4, 5.

354. M. novae-Iollandiae, Lath., New Holland Honey-eater.

General appearance black, white, and yellow ; feathers of mantle blackish-brown, edged with whitish and brownish-grey; feathers of fore-neck hairy, black, edged and tipped with white.

Hab. : $3,4,5$.

355. M. Iongirostris, Gld. (sub-sp. of M. novæ-hollandiæ), Long-billed Honey-eater. 
Very similar to M. novæ-hollandiæ, but feathers of white cheeks are a little longer and more hair-like, not forming a well-defined oval patch as in the other species. The bill is a little longer and stronger.

Bill, 0.8 to 0.9 in. ; wing, $2 \cdot 8$ to 3.1 in.

Hab. : (6), 9.

356. M. sericea, Gld., White-cheeked Honey-eater.

General appearance black, white, and yellow; feathers of mantle blackish-brown, edged with whitish and brownish-grey; feathers of fore-neck short, entirely black.

Hab. : 2, 3, 4 .

357. M. mystacalis, Gld., Moustached Honey-eater.

Adult female differs from M. sericea as follows:-The white feathers on upper part of head are restricted to the long superciliary stripe, leaving the middle part of forehead and base of culmen black ; the white elongated feathers of cheeks include some of the ear coverts and terminate in a point towards the shoulders.

Hab. : 9.

Gends-MANORHINA.-Post-auricular region bare of feathers.

358. M. melanophrys, Lath., Bell Minah (Bell-bird).

General colour of plumage olive-green above, under parts yellowish; red spot behind eye.

Hab. : 4.

359. M. obscura, Gld. (Myzantha obscura), Dusky Minah.

Mantle brownish-grey; abdomen white; rump and upper tail coverts like rest of back, dull grey; forehead and crown grey.

Hab. : (6), 9.

360. M. garrula, Lath. (Myzantha garrula), Noisy Minah.

Mantle brownish-grey; abdomen white ; breast arrow-marked; forehead whitish ; crown black.

Total length, 10 in.; bill, 1 in.; wing, 5 to 6 in.; tail, 5.5 in. Hab.: $3,4,5$.

361. M. flavigula, Gld. (Myzantha flavigula), Yellow-throated Minah. Mantle brownish-grey; abdomen white; rump and upper tail coverts white; breast arrow-barred. Wing, 5.5 to 4.8 in. ; tail, $4 \cdot 7$ to $4 \cdot 3$ in.

Hab. : 1, 3, 7, 9.

362. M. Intea, Gld. (sub-sp. of M. flavigula), (Myzantha lutea), Yellow Minah.

Wing, $5 \cdot 75$ in. ; tail, $5 \cdot 25$ in. Hab.: 1,8 .

GENUS-ACANTHOCH FRA.-Bill of about same length as rest of head, curved; culmen ridged; nostrils longitudinal and operculated; tail nearly as long as wing-5 to 7 in. - and graduated; tarsi scutellated and short.

363. A. carunculata, Lath., Red-wattle Bird.

Principal colours grey and brown, with white longitudinal marks. Wattles blood-red. Length of wattles less than $0.5 \mathrm{in}$. Hab. : 3, 4, 6, 7, 9.

364. A. inauris, Gld., Yellow-wattle Bird.

Similar to A. carunculata. Wattles yellow. Length of wattles more than 1 in. Hab. : 5 .

365. A. mellivora, Lath., Brush Wattle-bird.

Sub-gen. Anellobia has no wattles; tail strongly graduated.

Plumage dark, much lined and spotted with white; feathers of mantle with white central streaks.

Hab. : 3, 4, 5 . 
366. A. Iunulata, Gld., Little Wattle-bird.

Sub-gen. Anellobia (365).

No white streaks to feathers of mantle.

Hab. : 9.

367. A. rufigularis, Gld. (includes A. flavacanthus, Campbell), Spinycheeked Honey-eater.

Sub-gen. Acanthogenys has no wattles; tail not longer than wing, and square.

Throat to upper chest rufous ; abdomen white, heavily lined with brown; bristle-like feathers on cheeks and beneath ear coverts white.

Hab. : 3, 6, 7, 9.

Genus-ENTOMYZA.-Side of head bare.

368. E. cyanotis, Swainson, Blue-faced Honey-eater.

Head and throat black, with white crescent on occiput and white line dividing head from throat; under surface white ; basal half or two-thirds of inner webs of primaries fulvous.

Hab. : 2, 3, 6, 7 .

369. E. albipennis, Gld., White-quilled Honey-eater.

Like cyanotis, but with basal half or two-thirds of inner webs of primaries pure white.

Young has soft parts round the eye yellowish.

Hab. : 1, (2).

GeNOS-PHILEMON.-Culmen with prominent ridge, often humped.

370. P. corniculatus, Lath., Friar-bird (Leatherhead).

Base of culmen with large hump ; feathers of fore-neck and chest lanceolate in shape ; whole crown, sides of head and neck all round bare.

$$
\text { Hab. : 2, 3, 4, 6, } 11 .
$$

371. P. argenticeps, Gld., Silvery-crowned Friar-bird.

Base of culmen with large hump ; feathers of fore-neck and chest lanceolate in shape; nostrils open; centre of crown and sides of neck covered with silvery-brown feathers.

$$
\text { Hab. : 1, 2, } 8 .
$$

372. P. buceroides, Swainson, Helmeted Friar-bird.

Base of culmen with large hump ; feathers of fore-neck and chest lanceolate; centre of crown covered with feathers; side of neck bare.

$$
\text { Hab. : 1, } 2 .
$$

373. P. citreogularis, Gld., Yellow-throated Friar-bird.

Culmen not humped; upper surface light brown; under parts whitish; cheeks only and region round eye is bare; in very old birds also part of crown next to eye is bare.

Culmen, 1.5 to 1.2 in. ; wing, 5 to 5.2 in. ; tail, 4.1 in. ; tarsus, $1 \cdot 05$ in.

Young birds have yellowish throat.

$$
\text { Hab. : } 2,3,(4), 6,7 .
$$

374. P. sordidus, Gld. (sub-sp. of P. citreogularis), (includes P. occidentalis), Little Friar-bird.

Smaller (except in bill) than P. citreogularis. Hab. : 1, 3, 8. 


\section{SECTION B.-FRINGILLIFORMES.}

Wing with nine primaries, the first of which is fully developed and usually very long. Exceptions in Pardalotus and Prionochilus.

\section{FAMILY-DIC $\nexists I D A$.}

Differing from the Sun-birds by having stronger and shorter bills. The nesting habit also differs from that of the Sun-bird.

Genus-DICAUM.-Hind toe and claw about half length of tarsus.

375. D. hirundinaceum, Shaw, Flower-pecker or Mistletoe-bird.

Male. - Scarlet on throat ; back glossy purplish-blue ; flanks ashygrey.

Female.-Dull black above; throat and centre of abdomen buff ; under tail coverts pale scarlet.

Hab. : $6,7,8,9$.

Genus-PARDALOTUS.-Mandibles about equal ; nasal membrane concealed by plumes.

376. P. ornatus, Temm., Striated Pardalote.

Head streaked white on hinder crown and occiput; all primaries edged with white, forming large wing-patch ; tips of primary coverts scarlet.

Hab. : 2, 3, 4, 6, 7, 9.

377. P. assimilis, Ramsay (sub-sp. of P. ornatus), Allied Pardalote.

Head streaked white; third and fourth primaries edged with white (sometimes third only) ; tips of primary coverts scarlet, crimson, orange, or yellow.

Hab. : 2, 3, 4, 6, 7 .

378. P. affinis, Gld., Yellow-tipped Pardalote (Allied Pardalote).

Head streaked with white; third primary only edged with white ; tips of primary coverts always yellow.

Hab. : $3,4,5$.

379. P. punctatus, Temm., Spotted Pardalote.

Head black, with round white spots; back mottled; loral spot white ; under tail coverts yellow ; rump chestnut.

Hab. : 2, 3, 4, 5, 6, 7, 9.

380. P. xanthopygius, M'Coy, Yellow-rumped Pardalote.

Head black, with round white spots; back mottled; feathers edged with black, with subterminal spot; upper tail coverts crimson; loral spot white; under tail coverts and rump yellow.

Hab. : $6,7,9$.

351. P. Pubricatus, Gld, Red-lored Pardalote.

Hear black, with round white spots; back nearly uniform ashy. brown; loral spot scarlet; under tail coverts white.

Female has dusky centres and fringes to feathers of interscapular region, and conspicuous dark shaft lines on lower back. - North.

Hab. : 1, 2, 3, 5, 8, 10, 11.

3s2. P. melanocephalus, Gld., Black-headed Pardalote.

Head uniform black; rump yellowish or earthy-brown.

Hab. : 2, 3, 7.

3๖3. P. uropygialis, Gld., Chestnut-rumped Pardalote.

Male.-Head uniform black ; rump and throat yellowish.

Female.-Head greyish, as back ; throat whitish.

- Hab.: 1, 3, 8. 
384. P. quadragintus, Gld., Forty-spotted Pardalote.

Head and back olive, slightly mottled, with blackish unargins to feathers ; ear coverts yellow ; no wing speculum.

Hab. : 5.

\section{FAMILY-HIRUNDINID $Æ$.}

Broad-billed Passeres, with nine primaries.

Sub-FAMily-Hirundinine.

True Swallows, with forked tails as far as Australia is concerned.

Gends-HIRUNDO.-Nostrils lateral, with distinct superior membrane.

385. II. neoxena, Gld., House Swallow.

Throat rust-red; abdomen white; ear coverts glossy blue, like back. Hab. : 2, 3, 4, 5, 6, 7, 9 .

386. H. javanica, Sparrm., Eastern Swallow.

Lar coverts brick-red, like sides of face; otherwise much like neoxena.

Hab. : 2.

GENOS-CHERAMCECA.-Nostrils open and exposed, with scarcely any superior membrane.

387. C. lencosternum, Gld., Black and White Swallow (Whitebreasted Swallow).

Crown of head white, with brown centres to feathers ; mantle, upper back, cheeks, throat, fore-neck, and breast white ; rump, upper tail coverts, and abdomen blue-black.

Hab. : 6, 7, 9 .

GENUS-PETROCHELIDON.-Nostrils without any superior membrane, round, and exposed.

388. P. nigricans, Vieill., Tree Martin.

Frontal band of sandy buff; rump whity-brown; throat whitish, with tiny black streaks; under surface whitish.

Hab. : 2, 3, 4, 5, 6, 7 .

359. P. ariel, Gld. (Lagenoplastes ariel), Fairy Martin.

Entire head rufous ; rump creamy-white; under surface whitish.

Hab. : 3, 4, 5, 6, 11, 14 .

\section{FAMILY-MOTACILLID $A$.}

Inner secondary quills are nearly as long as the primaries; bastard primary absent.

GENUS-ANTHUS. - Profile of culmen swollen from centre to tip.

390. A. australis, Vig. and Hors., Pipit (Ground-Lark).

General plumage tawny; outer tail feathers white, without any brown on the outer webs ; second, third, fourth, and fifth primaries distinctly emarginate.

Hab. : 2, 3, 4, 5, 6, 7, 8, 9.

\section{SECTION C.-STURNIFORMES.}

This section is an artificial one.-R. B. Sharpe.

\section{FAMILY-ARTAMIDÆ.}

Planta tarsi entire; nostrils placed low in the bill, nearer to the tomium than to the culmen; wings extremely long, reaching to the end of the tail. 
Gends-ARTAMUS. - Bill long and pointed, the culmen exceeding the length of the hind toe and claw.

391. A. leucogaster, Valenc. (A. leucopygialis, Gld.), White-rumped Wood-Swallow.

Breast white; lower rump and upper tail coverts pure white; other parts sooty-grey.

Hab. : $1,2,3,4,6,7,8$.

392. A. superciliosus, Gld., White-browed Wood-Swallow.

Under surface of body vinaceous chestuut; a broad white eyebrow.

Hab. : 3, 4, 6.

393. A. personatus, Gld., Masked Wood-Swallow.

Under surface of body beautiful grey; rump and upper tail coverts clear ashy-grey, like the back. Male, face and throat jet black; female lighter.

Hab. : 3, 4, 6, 7, 9.

394. A. cinereus, Vieill., Grey-breasted Wood-Swallow.

A narrow blackish frontal line; rump and upper tail coverts black; under surface of body ashy-grey ; chin black; under tail coverts black, broadly margined with white.

Hab. : 9.

395. A. melanops, GId., Black-faced Wood-Swallow.

A narrow blackish frontal line; rump and upper tail coverts black; under tail coverts black, narrowly edged with white.

Hab. : 1, 6, 7, 8, 9.

396. A. venustus, Gld., White-vented Wood-Swallow.

No frontal line of black; chin itself and angle in front of eye black; two centre tail feathers entirely black, the rest tipped with white.

Hab.: 7,8 .

397. A. hypolencus, Sharpe (A. albiventris, Gld.), White-bellied Wood-Swallow.

Rump and upper tail coverts black; under surface of body ashygrey ; chin black ; under tail coverts white.

Hab. : 2, 6, 7 .

398. A. sordidus, Lath., Wood-Swallow.

Under surface of body dull brown; chin scarcely any darker; rump uniform with back (brown).

Total length, 7 in.; wing, 5 in.

Hab: $2,3,4,5,6,7,9$.

399. A. minor, Vieill., Little Wood-Swallow.

Rump and upper tail coverts black; under surface of body dull brown, chin scarcely any darker; rump different from back, which is brown.

Total length, $5 \cdot 75$ in. ; wing, 4 in.

Hab.: 1, 2, 3, 8, 9 .

\section{FAMILY-STURNIDA.}

Planta tarsi entire; nostrils placed low in the bill; wings moderate, not reaching to the end of the tail.

\section{SUB-FAMILY-STURNINE.}

Hind claw stronger than claw of middle toe.

GENUS-CALORNIS.-Tail strongly graduated.

400. C. metallica, Temm., Shining Starling.

General colour above glossy green on scapulars, lower back, and rump, with faint purple shade; lesser wing coverts and mantle 
glossy purplish-violet; middle coverts, like scapulars, greater coverts, primary coverts, and quills, black ; tail feathers black, glossed with dull steel-blue; crown of head purple-violet to nape; hind-neck glossy green; cheeks, chin, and throat steel-green ; fore-neck violet; chest and remainder of under surface of body steel-green ; iris cinnabar.

Total length, $9 \cdot 2$ in. ; culmen, 0.75 in. ; wing, 4.3 in. ; tail, 4 in. ; tarsus, 0.8 in.

Adult female like male, but iris blood red.

Hab. : 2.

\section{FAMILY-PLOCEID E : WeAVERS.}

Planta tarsi entire; nostrils placed high in the bill, nearer to the culmen than to the tomium.

\section{SUB-FAMILY-VIDUINE.}

First primary very small and falcate, attenuated towards the end, this first primary never reaching beyond the primary coverts and generally falling conspicuously short of the latter.

GENUS-STAGANOPLEURA.-Tip of wing from tip of tail about equals length of tarsus.

401. S. guttata, Shaw (Amadina lathami, Vig. and Hors.), Spottedsided Finch.

Crown of head and back of neck brownish-grey ; back and wings dark brown ; line round eye, band across chest, tail and flanks black, each feather of flanks having large oval spot of white near tip ; rump and upper tail coverts bright scarlet.

Young.-Bill black ; flanks barred.

Hab. : $3,4,6,7$.

GENUS-ZON FGINTHUS.-Tip of wing from tip of tail is longer than tarsus.

402. Z. bellus, Lath. (Estrilda bella), Fire-tailed Finch.

Lores, a line across forehead, and circle round eye black; upper surface, wings, and tail olive-brown, crossed with numerous fine crescents of black; rump and base of tail feathers scarlet; under surface grey, crossed with crescentic black bars.

Hab. : 3, 4, 5, 6, 7.

403. Z. oculatus, Quoy and Gaim. (Estrilda oculea), Red-eared Finch. General colour above brown, with wavy cross lines of black; rump and upper tail coverts crinison ; a narrow frontal line, lores, and feathers below eye black; below hinder part of eye a spot of crimson; ear coverts, cheeks, throat, and chest paler brown, very finely vermicnlated on sides of face and throat, more coarsely on fore-neck and chest ; rest of under surface white, barred with black, the spots more ovate on sides of breast.

Hab. : 9.

Genus-EMBLEMA.-Bill very long, pointed and slender.

404. E. picta, Gld., Painted Finch.

Adult Male.-General colour above pale brown; upper tail coverts rich scarlet; head brown, like back, as also the sides of face and of neck ; lores, a narrow eyebrow; feathers below eye and fore part of cheelss scarlet; throat and under surface of body black; chin and upper throat with scarlet-tipped feathers ; centre of foreneck and chest also scarlet; sides of breast and abdomen spotted white. 
Adult Female.-Similar, but with only the lores and feathers above eye scarlet; no red on cheeks or throat; only a tinge of scarlet on breast.

Hab.: 7, 8.

Genus-TENIOPYGIA.-Upper and under tail coverts reaching to near end of tail.

405. T. castanotis, Gld. (Estrilda castanotis), Chestnut-eared Finch.

Crown of head, nape of neck and back brownish-grey; a white patch in front of eye ; ear coverts chestnut ; flanks reddish-chestnut, each feather marked with oval spot of white near tip; throat and chest grey, crossed with black lines.

Adult female has entirely grey sides to face; lores and cheeks white; throat and chest uniform ashy-grey, with no cross black lines.

Hab. : 1, 6, 7, 8, 9.

GENUS-STICTOPTERA. - Bill triangular; tail strongly graduated.

406. S. bichenovii, Vig. and Hors. (Estrilda bichenovii); Bicheno Finch.

Crown of head and back brownish, each feather pencilled with darker shade; wings freckled grey; rump white, under surface light coloured, crossed by one band on throat and another on breast ; bill light bluish.

Hab. : 1, 2, 3, 6, 7.

407. S. annulosa, Gld., Black-ringed Finch (Black-rumped Finch).

Adult Male.-Similar to S. bichenovii, but having rump black instead of white; iris reddish-brown.

Adult Female.-Similar to male ; iris brown.

Hab. : 1, 8.

Genus-MUNIA.-Bill swollen; culmen strongly arched.

408. M. castaneithorax, Gld. (Donacicola castaneothorax), Chestnutbreasted Finch.

Reddish-brown or buff, with broad band of light chestnut on breast, ornamented below with a black line; rest of under surface white.

Hab. : 1, 2, 3, 4 .

409. M. flaviprymna, Gld., Yellow-rumped Finch.

Chestnut-brown; upper tail coverts golden ochre; tail feathers brown, with straw-coloured margins; scapulars and wing coverts brown, like back; quills dusky brown, externally edged chestnut ; head all round hoary grey ; white on throat ; under surface of body creamy-buff, tinged with fawn on breast; thighs brown.

Hab. : 1.

410. M. pectoralis, Gld. (Donacicola pectoralis), White-breasted Finch. Above lavender-grey; quills dusky ; tail blackish-brown; head like back ; lores, sides of face, and ear coverts, as well as throat, purplish-black ; fore-neck black, with patch of broad white-tipped black feathers; sides of body pale vinaceous brown, ornamented with white bars, edged with black line on each side of bar.

Hab.: 1, 8 .

GkNus-AIDEMOSYNE. - Tail graduated, two middle feathers not pointed (blunt).

411. A. modesta, Gld. (Estrilda modesta), Plum-head Finch (Plaincoloured Finch).

Fore part of head deep crimson; chin black; upper surface blackish-brown; rump and upper tail coverts with alternate bars of 
white and brown ; under surface white, barred with lines of brown; bill black.

Hab. : 3, 7.

GENUS-AGINTHA.-Upper mandible deeper than the lower.

412. E. temporalis, Lath., Red-browed Finch.

Rump, patch over eye, and bill crimson; upper surface, wings, and tail dark olive-brown.

Hab. : 2, 3, 4 .

GENus-BATHILDA.-Tail very long.

413. B. ruficauda, Gld. (Estrilda ruficauda), Red-faced Finch.

Male. - Face and cheeks scarlet, the cheeks covered with narrow feathers finely spotted with white at tip; upper tail coverts and tail deep crimson-brown, the former having a large spot of white near tip of each feather.

Female.-Uniform buffy-brown.

Hab. : 1, 2, 3, 7, 8 .

Genus-POEPHILA.-Centre tail feathers have thread-like points.

414. P. acuticauda, Gld. (Estrilda acuticauda), Long-tailed Finch.

Long central tail feathers nearly 4 in. ; crown of head and cheeks grey; upper and under surfaces fawn; upper tail coverts white; black band across rump ; shield of black under chin.

Hab. : 1, 8.

415. P. cincta, Black-throated Grass-Finch.

Back reddish-brown; throat black; upper tail coverts white; sides of lower abdomen black ; head grey ; black band across rump; bill black; breast tawny.

Hab. : 2, 3, (6).

416. P. personata, Gld., Masked Finch.

Black velvety ring on face, surrounding a yellow bill ; lower part of abdomen black ; lower rump, upper and under tail coverts white ; head and back light brown; ear coverts like breast.

Hab. : 1 ,

417. P. leucotis, Gld., White-eared Finch.

Back brown; upper tail coverts white; sides of lower abdomen black; head like back ; ear coverts white, contrasting with breast. $\mathrm{Hab}$ : 1 .

418. P. mirabilis, Hombr. and Jacq., Scarlet-headed Grass-Finch.

Back green, with blue on hinder crown, sides of neck, rump, and upper tail coverts; forehead crimson; vertex black, followed by blue line ; breast purple ; abdomen yellow.

Young.-Head grey; upper surface light olive; under surface light buff.

Hab. : $1,8$.

P. gouldiae, Gld. (var. of P. mirabilis, Ramsay), Gouldian Finch.

Head black, followed by blue line. Hab. : 1, 2, 8 .

P. armitiana, Ramsay (var. of P. mirabilis), Yellow.headed GrassFinch.

P.L.S. N.S.W., vol. ii., p. 70.

Head yellow.

Hab. : 1, 8.

419. P. atropygialis, Diggles, Black-rumped Finch.

Diggles, Queensland Phil. Soc., 876.

Doubtful species.

Hab. : 1. 
GENUS-NEOCHMIA.-Nostrils exposed, feathers partly hiding them.

420. N. phaeton, Hombr. and Jacq. (Estrilda phaeton), Crimson Finch. Male.-Crimson, tinged with brown on top of head and wings; a few white spots on sides.

Female.-Less red on under surface.

Hab. : 1, 2, 8.

\section{FAMILY-ALAUDID E : LARKS.}

Planta tarsi scutellated.

GENus-MIRAFRA.-Nostrils exposed, with a superior membrane.

421. M. horsfieldi, Gld., Bush-Lark.

Head grey, like the back, with blackish centres to the feathers. Wing, $2 \cdot 9$ in.

In the field like Anthus (390), but smaller, and with stronger bill. Hab. : 1, 2, 3, 4, 6, 7, 8, 9.

422. M. Secunda (Sharpe), Lesser Bush-Lark.

Eyebrow isabelline or tawny-buff; shoulder of wing almost entirely rufous, the median and greater coverts showing scarcely any black bases to the feathers; first small primary, 0.5 in. in length.

Hab. : 6.

\section{Subdivision II.-Passeres Abnormales.}

\section{FAMILY-ATRICHIID $A$ : SMooth-SKINNED BirdS.}

Furcula rudimentary.

Genus-ATRICHIA. - Wing is very tiny. Planta tarsi are more closely scutellated than in any lark.

423. A. clamosa, Gld., Noisy Scrub-bird.

General colour above dark chocolate-brown, waved with circular markings of black, black and brown colours alternating; tail feathers black, varied with alternate wavy markings of brown and black on margins ; lores and sides of face dusky-brown; throat and breast white, with a black patch on lower throat.

Total length, 8.5 in. ; culmen, 0.75 in. ; wing, 3 in. ; tail, $4 \cdot 1$ in. ; tarsus, 1.05 in.

Hab.: 9.

423A. A. rufescens, Ramsay, Rufous Scrub-bird.

More rufous than A. clamosa, and has upper tail coverts and tail feathers regularly barred with black; underneath throat is whitish, gradually becoming ashy; centre of breast is black ; abdomen clear orange-rufous.

Total length, 6.8 in.; culmen, 0.6 in. ; wing, 2.5 in. ; tail, $2.8 \mathrm{in.}$; tarsus, $0.8 \mathrm{in}$.

Hab. : $3,4$.

\section{FAMILY-MENURID $Æ$.}

Tail feathers of extraordinary length, many devoid of hooklets (radioli).

Genus-MENURA.-Tail lyre-like.

424. M. Superba, Davies, Lyre-bird.

Outer tail feather ashy-white on inner web, with rufous notches, and tipped with black; ashy-white below, the bars being reddish- 
brown ; under tail coverts ashy; back ashy-brown. Female has a less singular tail.

Hab. : 4 (N.S.W.)

425. M. victoriae, Gld., Victoria Lyre-bird.

Outer tail feather white below, bars being chestnut; under tail coverts ashy; back ashy-brown. Female has a less singular tail.

Hab. : 4 (Vic.)

426. M. alberti, Gld., Albert Lyre-bird.

Outer tail feather not barred ; under tail coverts chestnut; upper surface also rufous-brown or dull chestnut. Female.-Tail less singular.

Hab. : 3.

\section{DIVISION II.-MESOMYODI.}

Intrinsic muscles of the voice organ affixed at or near the middle of the bronchial semi-rings.

\section{Subdivision I.-Oligomyodæ.}

Lower end of trachea not modified; syrinx as in the Oscines, but with a lesser number of singing muscles.

FAMILY-PITTID $Æ$ : ANT-Thrushes.

Plantar vinculum lost; manubrium forked; tarsus ocreate; rectrices twelve.

Genus-PITTA.-Tail short, more or less squared. 427. P. strepitans, Temm. (including P. simillima, Gld.), Noisy

Above dark green; crown dark chestnut-brown, with a slight black vertical stripe; sides of head, nape, and back of neck black ; wing feathers black, with white speculum; beneath pale fawn colour; throat and centre of neck black; patch in centre of abdomen black; lower belly scarlet; tail black, tipped with greenish.

P. simillima represents the species in the North, and is smaller; there are "go-betweens."

Total length, $8 \cdot 5$ in. ; wing, 5 in. ; tail, 2 in. Hab. : 2, 3.

428. P. mackloti, Temm., Blue-breasted Pitta.

Above dull green; rump, upper tail coverts, and wing coverts blue; wing feathers black, with white speculum; head reddishbrown; chin brown, passing into large black guttural patch ; broad breast band greyish-blue, bordered below with wide black margin , abdomen scarlet.

Total length, 7 in. ; wing, 4 in. ; tail, $1 \cdot 6$ in. Hab. : 2.

429. P. iris, Gld., Rainbow Pitta.

Above green; whole head and nape black, with broad stripe from behind each eye, joining at nape, chestnut; lesser wing coverts bright silvery-blue, tipped with purple ; narrow rump band silvery-green ; tail black, broadly tipped with green; beneath black; lower belly and vent scarlet.

Total length, 6 in.; wing, 4 in. ; tail, $1 \cdot 4$ in. Hab.: 1. 


\section{ORDIR-PICARIF.}

Opposed to the Passeres (Nitzsch). The feet are relatively weaker and smaller.

\section{Sub-order-Coraciæ.}

Spinal feather-tract well defined on the neck by lateral bare tracts, but dividing into two tracts on the upper back ; oil gland nude if present.

\section{FAMILY-CYPSELID AE.}

Palate ægithognathous. Rectrices ten (Swallows have twelve). Gape very wide.

\section{Sub-FAMILY-CyPSELINE.}

Tarsi distinctly feathered, outer and middle toes with only three phalanges.

GENOS-MICROPUS.-Hind toe directed more or less forward.

430. M. pacificus, Lath. (Cypselus pacificus), White-rumped Swift (Australian Swift).

Rump white; feathers of under surface edged with white, and with a darker subterminal bar.

Wing, 7 to $7 \cdot 3$ in. ; lateral rectrices, $3 \cdot 3$ in. Hab. : $2,3,4,6,7$.

\section{SUB-FAMILY-ChetURINA.}

Wings always reaching far beyond end of tail.

GENUS-CH ETURA. - Shafts of rectrices have spinous points; tarsi as long or longer than middle toe.

431. C. caudacuta, Lath., Spine-tailed Swift.

Chin and throat pure white; small white band across forehead. Hab. : 1 to 9 .

Genos-CALLOCALIA.-Shafts of rectrices have no spinous points.

432. C. francica, Gmelin (C. terræ reginæ), Grey-rumped Swiftlet.

Crown, nape, and back dark smoky-brown; rump brownish-grey, with dark shaft lines; lower surface dusky brownish-grey, feathers with dark shaft lines; chin and upper throat a little darker.

Total length, over 4 in. ; wing, $4 \cdot 4$ in.; tail, 2 in.

Hab. : 2.

\section{FAMILY-CAPRIMULGID $A$.}

The mouth is split very wide, and gape is very wide; colours vary with the soil ; habits nocturnal.

\section{SUB-FAMILY-CAPRIMULGINE.}

Has ten primaries and ten rectrices ; number of phalanges reduced to four in outer toe, and claw of middle toe peculiarly pectinated.

Genus-CAPRIMULGUS.-Rictus is armed with strong bristles.

433. C. macrurus, Hors., Large-tailed Nightjar.

Freckled brown, with large white marks near throat; four outer primaries with white spots.

Total length, 11.5 in. ; wing, $7 \cdot 5$ in. ; tail, $5 \cdot 6$ to 6.3 in. ; tarsus, 0.7 in., feathered in front for nearly whole length.

Hab. : 1, 2, 3, 4, 6, 7, 9. 
GENUS-EUROSTOPUS.-Rictus without conspicuous bristles.

434. E. albigularis, Vig. and Hors. (Eurostopodus albogularis), White-throated Nightjar.

Freckled grey and brown; large patch of white at side of neck.

Wing more than 9.5 in. (about 10 in.); tail, $6 \cdot 2$ in.

Hab. : 3, 4, 6, 7 .

435. E. argus. Hartert (Eurostopodus guttatus, Gld.), Spotted Nightjar.

Wing less than 9 in. ; tail, $6 \cdot 4$ in.

Also distinguished from E. albigularis by its uniform rusty-brown abdomen and under tail coverts.

Hab. : 1 to 4,6 to 9 .

\section{FAMILY-PODARGID $A$.}

Gape very wide; mouth very much split; palate desmognathous.

\section{SUB-FAMILY-PODARGINE.}

Nostrils a narrow split near the base of the bill, protected by a membrane, and hidden by plumes of feathers; tarsus shorter than middle toe; fourth and fifth or fifth and sixth primaries longest.

Gends-PODARGUS.-Rectrices pointed, the central pair much longer than the adjoining pair.

436. P. papuensis, Quoy and Gaim. (including P. plumiferus), Plumed Frogmouth.

Male.-Mottled grey and brown above; lower parts lighter, and with white spots.

Female.-Rusty-rufous above; lower surface strongly shaded with rufous and mottled.

Tail distinctly more than $10 \mathrm{in.}$

Hab. : 2, 3.

437. P. strigoides, Lath. (includes P. cuvieri, Vig. and Hors; gouldi, Masters; megacephalus, Lath.), Tawny Frogmouth (Podargus).

General plumage tawny.

Tail distinctly less than 10 in. ; wing more than 9 in.

Hab. : $1,2,3,4,5,6,7,8$.

438. P. phalaenoides, Gld. (includes P. brachypterus, Gld.), Freckled Frogmouth (Moth-plumed Podargus).

General plumage freckled.

Tail distinctly less than 10 in.; wing less than 9 in. (about 8 in.) Hab. : 1, 2, 9.

439. P. marmoratus, Gld. (sub-sp. of P. ocellatus, Quoy. and Gaim.), Marbled Frogmouth.

Tail exceeds $10 \mathrm{in}$; wing less than 9 in. (about 7.5 to 8.5 in.)

Hab. : 2, 3.

\section{SUB-FAMILY - AGGOTHELINE.}

Nostrils situated near tip of bill; third and fourth quills longest.

GENuS- EGOTHELES.-Pale nuchal collar.

440. A. novae-hollandiae, Lath. (includes A. leucogaster, Gld.), Owlet Nightjar.

Adult. - Top of head deep brown, with two longitudinal stripes and two crescents on hinder part whitish; back, rump, upper wing coverts, and upper tail coverts deeply vermiculated with pale grey; quills dusky; outer webs with pale grey margins and spots; tail dusky, with twelve or more whitish-grey bars; sides of head 
whitish, often tinged with rufous ; lower parts whitish, with dusky vermiculations.

Total length, 8.5 in. ; wing, 5 in. ; tail, 4.75 in. ; tarsus, 0.9 in. Hab. : $1,2,3,4,5,6,7,8,9$.

\section{FAMILY_CORACIID $\approx$ : ROLLERS.}

Bill corvine in shape ; culmen rounded ; nostrils placed near base of upper mandible and hidden by bristly feathers; tail feathers twelve.

\section{SUb-FAMILY-Coracirne.}

Tarsus less than half length of middle toe.

GenUs-EURYSTOMUS.-Bill as broad at gape as it is long.

441. E. australis, Swainson (E. pacificus, Lath.), Dollar-bird or Roller. Head and neck dark brown; upper surface sea-green; spurious wing, outer webs of basal part of secondaries, and middle part of primaries and throat light blue; base of primaries greenish-white, tip dark brown; tail green at base, dark brown at tips; under surface green ; iris dark brown ; bill, legs, and feet red.

Total length, $10 \cdot 5$ in. ; bill, $1 \cdot 1$ in. ; wing, $7 \cdot 75$ in.

Hab. : 2, 3, 4, 6, (8).

\section{FAMILY-MEROPID $\AA$.}

Bill long; culmen with sharply defined ridge; feet syndactyl.

GENus-MEROPS.-Centre tail feathers elongated.

442. M. ornatus, Lath., Bee-eater.

Mantle green; a broad black patch on the fore-neck; tail black, the centre feathers washed or edged with blue.

Hab. : 1 to 4,6 to 9 .

\section{Sub-order-Zalcyones.}

Spinal feather tract well defined on the neck and not forked on the back. No after shaft to the contour feathers of the body.

\section{FAMILY-ALCEDINID $Æ$.}

Toes anisodactyl; bill not serrated; cæca, none.

\section{SUB-FAMILY - AlCEDININA.}

Bill long and slender, compressed and perceptibly keeled. Habits mainly insectivorous.

Gents-ALCYONE.--Toes three; bill longer than tail, which is very short.

443. A. azurea, Lath. (includes A. diemenensis, Gld.), Azure Kingfisher.

Head and back azure; sides of body rufous, like breast, or only slightly washed with lilac.

Hab. : 2, 3, 4, 5 .

444. A. pulchra, Gld. (sub-sp. of A. azurea, Lath.), Purple Kingfisher. Breast ultramarine, continued from sides of upper breast. Hab. : 1, 2, 8 .

445. A. pusilla, Temm., Little Kingfisher.

Abdomen white; upper surface blue; lores and tufts behind ear coverts white.

Total length, 4.8 in. ; culmen, $1 \cdot 1$ in. ; wing, 2 in. ; tail, 0.8 in.; tarsus, $0 \cdot 25$ in.

Hab. : 1, 2. 


\section{SUB-FAMili - DaCELONINA.}

Bill more or less depressed; culmen rounded or flattened, and even grooved.

$$
\text { Genus-SYMA.-Tomia serrated. }
$$

446. S. flavirostris, Gld., Yellow-billed Kingfisher.

Adult Male.-Back and scapulars greenish-brown; quills blackish, externally bluish-green, except first primary, which is edged with buff; lower back, rump, and upper tail coverts dull greenish-blue ; tail dark blue; head and hind-neck, as well as under surface of body, cinnamon-rufous; bill all yellow.

Female. - Black patch in centre of crown ; broken collar.

Total length, 7 in. ; culmen, 1.5 in. ; wing, 3 in. ; tail, 2.3 in.; tarsus, 0.5 in.

Hab. : 1, 2.

Genus-DACELO. - Culmen ascending towards end of upper mandible.

447. D. gigas, Bodd., Brown Kingfisher (Laughing Jackass).

Crown rufous-brown in centre; white on sides of crown; a band of brown on nape.

Hab. : (2), 3, 4, 6, 7.

448. D. leachii, Vig. and Hors., Leach Kingfisher.

Head distinctly striped; portion of wing and upper tail coverts blue; upper surface strongly marked. Male has blue tail ; female a red one.

Total length, 17 in. ; culmen, 3 in. ; wing, 8 in.; tail, 5 in.; tarsus, 1 in.

Hab. : 1, 2, 3.

449. D. cervina, Gld., sub-sp. (includes D. occidentalis, Gld.), Fawnbreasted Kingfisher.

Similar to D. leachii, but smaller, and with a similar blue tail, but slightly fulvescent below. Adult female has cinnamon tail, barred with blue.

Total length, 15 in.; culmen, 3 in. ; wing, $7 \cdot 5$ in.; tail, 5 in. ; tarsus, 1 in.

$$
\text { Hab. : 1, 2, } 8 .
$$

GEnds-HALCYON.-Bill compressed; culmen grooved laterally.

450. H. macleayi, Jardine and Selby, Macleay Kingfisher.

Crown of head deep ultramarine blue; mantle blue; under tail coverts white; under surface white. Male, but not female, has white collar on hind-neck.

Hab. : $1,2,3,4,8$.

451. H. pyrrhopygius, Gld., Red-backed Kingfisher.

Back and rump cinnamon; head green, streaked with white; under surface white.

Hab.: 1 to 4,6 to 9 .

452. H. Sanctus, Vig. and Hors., Sacred Kingfisher.

Head greenish blue; upper surface dull green; under surface of body and under wing coverts orange buff, as also the collar.

Hab. : 1 to 9.

453. H. Sordidus, Gld., Mangrove Kingfisher.

Head and back dusky-green or blackish; under surface of body and under wing coverts white, sometimes with a slight shade of buff on sides and under wing coverts.

Hab. : 1, 2, 3. 
GENUS-TANYSIPTERA.-Centre tail feathers elongated and spatulate. 454. T. sylvia, Gld., White-tailed Kingfisher.

Head purplish blue; mantle black; wing coverts ultramarine; under surface cinnamon.

Male.-Total length, 13 in.; culmen, 1.3 in.; wing, 3.8 in.; central tail feathers, 9 in.; tarsus, 0.5 in.

Female.-Total length, $9 \cdot 6$ in.; longest feather of tail, $5 \cdot 2$ in. ; other feathers, $2 \cdot 2$ in.

Hab. : 2.

\section{Sub=order-Coccyges.}

Feet zygodactyl or semi-zygodactyl.

\section{FAMILY-CUCULID Æ.}

Feet zygodactyl; spinal tract furcate between the shoulders; cæca present.

\section{Sub-Family-Cuculine.}

Wing long and flat, not fitting to the body.

GeNUS - CUCULUS. - Tail fan-shaped; wings reaching beyond tail coverts ; under surface of quills barred.

455. C. intermedius, Vahl. (C. canoroides, S. Müll.; C. optatus, Gld.), Oriental Cuckoo.

Head, throat, and back blue-grey ; breast whitish, barred with black.

Hab. : 2, 3.

456. C. pallidus, Lath., Pallid Cuckoo.

Whole appearance grey; eyelash yellow ; tail barred with white; breast uniform, not barred with white and black.

Hab. : 1 to 9.

GENUS-CACOMANTIS. - Tail fan-shaped; wings not reaching to end of tail coverts ; under surface of wing with single oblique white bar.

457. C. flabelliformis, Lath. (Cuculus cineraceous, Vig. and Hors.), Fan-tailed Cuckoo (Ash-coloured Cuckoo).

Grey above; breast ferruginous; outer webs of tail feathers toothed with white; upper parts paler and greyer than following species. Wing, $5 \cdot 4$ in.

Hab. : 1 to 9 .

458. C. variolosus, Hors. (C. dumetorum ; C. tymbonomus, S. Müll.), Square-tailed Cuckoo.

Upper parts darker, brown; breast buff ; under tail coverts buff ; no white markings on outer webs of tail feathers.

Total length, $8 \cdot 5$ in. ; wing, $4 \cdot 8$ in.

Hab. : $1,2,3,4,6,8,9$.

C. insperatus is not considered an Australian bird (British Museum Catalogue Birds, xix., p. 273).

Upper parts darker than C. flabelliformis; breast darker than C. variolosus, partially washed with rufous; under tail coverts rufous; no white markings on outer webs of tail feather.

Total length, 8 in. ; wing, $4 \cdot 4$ in.

459. C. castaneiventris, Gld., Chestnut-breasted Cuckoo.

Upper parts deep blue-grey, barely glossed with green on wings only ; breast bright rufous; under tail coverts chestnut.

Hab. : 2. 


\section{GENUS-MISOCALIUS.-Tail square.}

460. M. palliolatus, Lath., Black-eared Cuckoo.

Ashy-brown; quills dark brown; outermost upper tail coverts with broad white marginal ends and some faint bars; all tail feathers with broad whitish ends, and five other distinct white bars on inner webs of outer pairs; on sides of head a broad white eyebrow and a black band through eye over ear coverts; under surface of body rufous-buff; white on abdomen, thighs, and under tail coverts.

Total length, $7 \cdot 5$ in.; bill, $0 \cdot 75$ in. ; wing, $4 \cdot 75$ in.

Hab. : $1,6,7,8,9$.

GENUS-CHALCOCOCCYX. - Under surface of quills with a single oblique pale bar.

461. C. basalis, Hors. (Chalcites basalis), Narrow-billed Bronze Cuckoo.

Basal two-thirds of tail rufous, except outer feathers, which are blackish, with six broad white bars (British Museum Catalogue); outer tail feather on each side alternately and broadly barred with blackish-brown and white, the three next on each side rufouschestnut at base, passing into green towards extremity, and ending in blackish-brown spotted with white (Gould).

Hab. : 1 to 9 .

462. C. plagosus, Lath. (Chalcites plagosus), Bronze Cuckoo.

Basal half of tail never uniform rufous; no rufous edges to quills and with less rufous on under surface of wings and outer pair of tail feathers ; crown and back of neck dark violet-brown.

Total length, $6 \cdot 2$ in. ; wing, 4 in. ; tail, 3 in.

Hab. : 1 to 9.

463. C. lucidus, Lath., Broad-billed Bronze Cuckoo.

Similar to C. plagosus; bill stronger; crown and back of neck green; penultimate tail feather with less rufous than in C. plagosus. Hab. : 2, 3.

464. C. pæecilurus, Gray (includes C. russatus, Gld., and C. minutellus, Gld.), Rufous-throated Bronze Cuckoo.

Basal half of tail never uniform rufous; narrow rufous edges to quills, and more rufous on under surface of wings and outer pair of tail feathers.

Total length, 5.8 in. ; culmen, 0.5 in.; wing, 3.7 in. (less than 4 in.)

C. malayanus, Raffl., is not considered an Australian bird (British Museum Catalogue Birds, xix., p. 298).

Hab. : $1,2,8$.

GENUS-EUDYNAMIS. - Fourth quill longest or equal to third.

465. E. cyanocephala, Lath. (E. flindersii, Vig. and Hors.), Koel.

Adult Male.-Black, with bright greenish-blue gloss.

Total length, 16 in.; bill, $1 \cdot 2$ in.; wing, 8 in.; tail, $8 \cdot 4$ in.; tarsus, $1 \cdot 3$ in.

Adult Female.-Upper half of head and back of neck glossy greenish-black; rest of upper parts dark brown, with an olive gloss ; back and wing coverts thickly spotted with white; quills, rump, and tail feathers with numerous white bars; chin and upper throat black, with white spots; rest of under parts whitish, with narrow black bars.

Hab. : $1,2,3,(7), 8$.

GENUS-SCYTHROPS.-Bill very large ; culmen has a lateral groove.

466. S. novae-hollandiae, Lath., Channel-bill.

Head, throat, nape, and upper part of breast drab and buff; back dull brown; lower part of breast and abdomen greyish-yellow, with pale wavy marking; bill horn colour ; iris red. 
Total length, 24 in.; bill, 2.9 in. ; wing, 13 in.; tail, 11 in.; tarsus, $1 \cdot 75$ in.

Hab. : 1 to 8 .

\section{Sub-Family-Centropodina.}

Wings shorter (than Cuculinæ), and curved to fit the body.

GENUS-CENTROPUS.-Hind claw straight.

467. C. phasianus, Lath., Spur-footed Cuckoo (Coucal).

Adult.-Feathers of upper and under surface dull black, with glossy black shafts; wing coverts mottled with tawny brown and black ; remainder of wing rich chestnut, crossed with black bars; lower part of back deep green, freckled with black.

Young have all upper surface reddish-brown, with conspicuous glossy tawny shafts; throat and breast tawny, with lighter shafts.

Hab. : 1, 2, 3, 8.

\section{ORDER-PSITTACI.}

Feet permanently zygodactyl by reversion of the fourth toe; covered with plates. Bill short and very stout, strongly hooked or epignathous, and furnished with a cere.

\section{FAMILY-LORIID $Æ$.}

Bill longer than deep; under mandible with gonys nearly straight. Tongue brushy.

Gevus-TRICHOGLOSSUS.-Shaft streaks more or less blue on forehead (as on rest of head); breast generally tinged with red.

468. T. novae-hollandiae, Gmelin, Blue-bellied Lorikeet (Bluemountain).

Head and belly blue ; chest red; band on nape greenish-yellow. Hab. : 1, 2, 3, 4, 5, 6, 7 .

469. T. rubritorques. Vig. and Hors., Red-collared Lorikeet.

Head blue ; chest red; belly olive-green; band on nape orange. Hab. : $1,8,9$.

Genos-PSITTEUTELES.-Like Trichoglossus, only different colour; no blue shaft streaks; no red on breast; bill red.

470. P. chlorolepidotus, Kuhl. (Trichoglossus chlorolepidotus), Scaly-breasted Lorikeet.

All upper surface, wings, and tail grass-green ; all feathers of under surface bright yellow, margined at tip with crescent of grass-green ; under surface of shoulder rich scarlet.

Hab. : 2, 3, 6, 7 .

Genus-PTILOSCLERA.-Predominant colour green, with shaft streaks on neck and body; bill orange-red.

471. P. versicolor, Vigors (Trichoglossus versicolor), Varied Lorikeet. Back brownish-green; wings green ; red across breast; abdomen green; all feathers of under surface with narrow line of bright yellow down centre.

Hab. : $1,2,8$.

Genus-GLOSSOPSITTACUS.-Predominant colour green; bill black; first primary equal to or a little shorter than second and third.

472. G. conciumus, Shaw (Trichoglossus concinnus), Musk Lorikeet. General colour green; no red in cheeks ; ear coverts red, like forehead.

Hab. : 2, 3, 4, 5, 6, 7. 
473. G. porphyrocephalus, Dietr., Purple-crowned Lorikeet.

No red in cheeks ; ear coverts yellow, mixed with red, like forehead ; crown purple.

Hab. : 6, 7, 9 .

474. G. pusillus, Shaw, Little Lorikeet.

Cheeks, as well as forehead and chin all round the base of bill, red; general colour green.

Hab. : 2, 3, 4, 5, 6, 7 .

\section{FAMILY-CYCLOPSITTACID压.}

Bill deeper than long, much swollen on sides; under mandible with gonys strongly curved and abruptly ascending towards tip.

Genus-CYCLOPSITTACUS.-Gonys flattened and ridged.

475. C. Coxeni, Gld., Blue-faced Lorilet (Coxen's Fig Parrakeet). General plumage green; across forehead a narrow band of red, the centre tipped with blue; blue patch under ear coverts; primaries margined blue ; tail short and wholly green.

Total length, 7 in. ; wing, $3 \cdot 9$ in. Hab. : 3.

476. C. maccoyi, Gld. (C. macleayana), Red-faced Lorilet (Sir Wm. Macleay's Fig Parrakeet).

Smaller than preceding species ; wing, $3 \frac{1}{2}$ in. ; a broad patch of red on middle of forehead; a broad red band across cheeks in male; female without red on cheeks, which are grey tinged with blue.

Hab. : 2.

\section{FAMILY - CACATUID $Æ$.}

Hook of the bill beneath, with two lateral series of ridges more or less transversal or oblique, producing a file-like surface ; head crested ; orbital ring complete, with a process bridging the temporal fossa; tongue simple; sternum complete.

\section{SUB-FAMILY-CaCaTUINE.}

Tail feathers broad, not pointed.

Genus-MICROGLOSSUS.-Cheeks entirely naked.

477. M. aterrimus, Gmelin, Palm Cockatoo.

Slaty-black ; forehead and lores deep velvety black; a long crest of narrow feathers on the head.

Hab. : 2.

GeNus - CALYPTORHYNCHUS. - Colour black, principally; cheeks feathered.

478. C. baudini, Vigors, White-tailed Cockatoo.

Blackish-brown; has a light patch on ear coverts; tail banded with white.

Hab. : 9.

479. C. funereus, Shaw (includes var. C. xanothonotus, Ramsay), Black Cockatoo.

Brownish-black; has a yellow patch on ear coverts and tail banded with yellow; wing, $18 \mathrm{in}$. to $16 \mathrm{in}$. Wing of $\mathrm{C}$. xanothonotus measures 15 in. to 14 in. Gradation has been clearly shown between these forms.

Hab. : 3, 4, 5, 6. 
480. C. banksi, Lath., Banksian Black Cockatoo.

No light patch on ear coverts ; tail band red in adult males; red, more or less tinged with yellow and crossed with narrow black bands, in young birds; head and neck like body-glossy greenishblack; total length, about 24 in.

Young.-Head spotted yellow; under surface barred yellow. Hab. : 2, 3, 4, 7.

491. C. stellatus, Wagl. (C. naso, Gld.), Red-tailed Cockatoo (Western Black Cockatoo).

Differs from C. banksi and C. macrorhynchus in being smaller, with a shorter crest.

Total length, about 22 in.

Zool. Soc. Lond., 1898, part iii., p. 355.

Hab. : 8, 9.

482. C. macrorhynchis, Gld., Great-billed Cockatoo.

No light patch on ear coverts ; tail band red in adult males, more or less tinged with yellow and crossed with narrow black bands in young birds ; head and neck, like body, glossy greenish-black; total length, about 24 in.; bill larger and much more powerful than C. banksi.

Young.-Head yellow-spotted; under surface barred yellow. Hab. : 1, 2, 8.

4S3. C. viridis, Vieill. (C. solandri, Temm.), Leach Cockatoo.

No light patch on ear coverts ; tail band red in adult males; red, more or less tinged with yellow and crossed with narrow black bands, in young birds; head and neck brown; upper parts glossy greenish-black.

Hab. : 2, 3, 4, 6, 7.

Genus-CALLOCEPHALON.-Cere feathered.

484. C. galeatum. Lath., Gang-Gang Cockatoo.

Slaty-grey; nearly all feathers edged with greyish-white; pileum, crest, and cheeks fine scarlet. Female.-Crest grey.

Hab. : 3, 4, 5 .

GExus-CACATUA.-General colour white or rosy-white; hook of bill nearly perpendicular.

4S5. C galerita, Lath., White Cockatoo.

Crest feathers narrow and recurved at extremity ; crest yellow ; cere naked; body feathers white; naked skin round the eyes white. Hab. : 1 to 9.

4S6. C. leadbeateri, Vigors, Pink Cockatoo (Major Mitchell).

General plumage pink and white; crest feathers narrow and recurved at extremity ; crest vermilion at the base, with a yellow band in the middle of the vermilion part, white at the tip; cere feathered.

Hab. : 6, 7, 9 .

437. C. Sanguinea, Gld., Blood-stained Cockatoo.

White; base of feathers of lores and sides of face blood-red patches; naked skin round eyes white, and nearly circular.

Total length, 14 in. ; wing, 10 in.

Hab. : 1, 2, 3, 7 .

458. C. gymnopis, Sclater, Bare-eyed Cockatoo.

White; forehead and lores stained with red; naked skin round eyes blue, and largely extended into a bare open space below.

Total length, 16 in.; wing, 11 in.

Hab. : $1,2,6,7,8$. 
489. C roseicapilla, Vieill., Rose-breasted Cockatoo.

Crest feathers broadened and not recurved at extremity; under surface rose colour; upper surface grey.

Hab. : $1,6,7,8,(9)$.

GeNoS-LICMETIS. - Hook of bill is long, slender, and projects forwards.

490. L. nasica, Temm., Long-billed Cockatoo (Corella).

Mostly white; naked skin round the eyes light blue; lores and a narrow frontal band red.

Total length, 15 in. ; wing, 11 in.

Hab. : $1,6,7$.

491. L. pastinator, Gld., Dampier Cockatoo (Western Long-billed Cockatoo).

Like L. nasica, but a little larger; naked space round eye larger and darker, of blue lead colour.

Hab. : 9.

\section{SUb.FAMiLY-CaLOPSITTACINE. \\ Tail feathers narrow and pointed. \\ Genus-CALOPSITTACUS.-Crest is grey.}

492. C. nova-hollandiae, Gmelin, Cockatoo Parrakeet.

Dark grey ; forehead and cheeks lemon-yellow ; crest grey, with bases of feathers lemon-yellow; ear coverts reddish-orange. Female paler than male.

Total length, 12.5 in.

Hab. : $1,3,6,7,8$.

\section{FAMILY-PSITTACID $A$.}

As in Cacatuidæ, but with orbital ring mostly incomplete; if complete, no bridging of fossa. Head without a crest, excepting nymphicus (extra Australian).

\section{SUb-FAMILY - PaLAORNithine.}

Furcula present. Females mostly different from males.

GENus-POLYTELIS.-Tail feathers narrow, especially two centre ones.

493. P. barrabandi, Swainson, Green-Leek Parrakeet.

General colour green. Male with sinciput and throat yellow. Female with forehead and cheeks tinged with bluish, and inner webs of lateral tail feathers margined with rosy-red.

Hab. : 6,7 .

494. P. melanura, Vigors, Black-tailed Parrakeet.

Adult Male.-Whole of upper surface olivaceous-green of varying shades; tail feathers deep purplish blue, underneath black, with tips lighter; beak red.

Total length, 16 in.; bill, $0 \cdot 75$ in. ; wing, 7.5 in. ; tail, 8.5 in.

Female.-Head, sides of face, back of neck, upper part of back, dull olive-green ; throat, all under surface, rump, and wing coverts green; primaries, some secondaries, and spurious wing deep blueblack, nargined externally with yellowish green; rest of secondaries deep red; two centre tail feathers deep green, remainder green at base, black on inner webs.

Hab. : $6,7,9$. 
GENUS-SPATHOPTERUS (North). - The end of the third primary of the male is elongated and spatulate.

495. S. alexandrae, Gld. (Polytelis alexandræ), Alexandra Parrakeet. General colour green; forehead and rump bluish; lower part of cheeks and throat pale rose colour; inner webs of lateral tail feathers margined with rosy-red.

Hab. : 7, 8.

GENus-PTISTES.-Tail feathers very broad, almost equally long.

496. P. erythropterus, Gmelin (Aprosmictus erythropterus ; Aprosmictus coccineopterus), Red-winged Lory.

Adult Male.-Green, underneath yellowish-green; lower back and rump deep blue; primaries dark green; secondaries nearly black, the inner ones dark green; upper wing coverts rich crimson red, with base of feathers yellow.

Total length, 13 in.; wing, 8 to $7 \cdot 5$ in. ; tail, 5.5 to 5.25 in.

Adult Female.-Dull green, under surface yellowish-green; rump blue; some of outermost median upper wing coverts edged with red; the outermost greater upper wing coverts red; secondaries blackish-green.

P. coccineopterus, Gld., Crimson-winged Lory, is united in British Museum Catalogue with P. erythropterus, on the grounds that, although the northern birds have been specifically separated as A. coccineopterus on account of being generally smaller than the eastern ones, yet some are as large.

Hab. : 1, 2, 3, 8 .

GENUS-APROSMICTUS. - Tail feathers very broad; tail much graduated.

497. A. cyanopygius, Vieill. (A. scapulatus, Bech.), King Lory.

Adult Male.-Head, bill, neck, breast, and abdomen scarlet; back dark green.

Female. - Entirely green, except dull blue tail coverts; throat and chest tinged with red; abdomen and under tail coverts scarlet.

Young.-Like adult female, but has lateral tail feathers with rose-coloured tips.

Hab. : 3, 4.

\section{Sub-Family-Platycercina.}

Furcula absent ; bill moderate, never red.

GENUS-PLATYCERCUS.-Back not uniform, but with feathers broadly bordered, and having a scale-like appearance; bill distinctly notched.

498. P. elegans, Gmelin (P. pennantii, Lath.), Pennant's Parrakeet. Cheeks blue; under parts crimson.

Hab. : 2, 3, 4.

499. P. nigrescens, Ramsay, Campbell Parrakeet.

Northern variety of P. elegans. Smaller; more robust bill; deeper colour.

Hab. : Bellenden-Ker Range, Queensland.

500. P. adelaidae, Gld. (P. adelaidensis), Adelaide Parrakeet.

Cheeks blue; under parts pale red, each feather slightly fringed with yellowish.

Hab. : 6, 7 .

501. P. flaveolus, Gld, Yellow-rumped Parrakeet.

Cheeks blue; under parts pale or straw-yellow; median tail feathers dull blue.

Hab. : 6, 7 . 
502. P. flaviventris, Temm., Yellow-bellied Parrakeet.

Cheeks blue; under parts jonquil-yellow; median tail feathers dark olive-green.

Hab. : 4, 5, 6.

503. P. pallidiceps, Vigors, Pale-headed Parrakeet.

Cheeks white, bordered with blue below, sometimes entirely white or yellowish-white; head pale yellow ; feathers of back edged with bright yellow : under parts blue; under tail coverts red.

Hab. : 2, 3, 7 .

504. P. amathusia, Gld. (P. amathusiæ), Blue-cheeked Parrakeet.

Cheeks almost entirely blue, only on upper part white; head pale yellow; feathers of back edged straw-yellow; under parts blue; under tail coverts red.

Hab. : 1, 2.

505. P. browni, Temm., Smutty Parrakeet.

Cheeks white, bordered with blue below; head black; feathers of back with yellow margins; under tail coverts red.

Hab. : 1.

506. P. eximius, Shaw, Rosella.

Cheeks white ; head red ; feathers of back edged yellowish-green ; upper tail coverts green.

Hab. : 3, 4, 5, 6,7 .

507. P. erythropeplus, Salvad., Red-backed Rosella.

Intermediate between $P$. elegans and $P$. eximius. Cheeks white and blue; under tail coverts red; head red. Single specimen.

Hab. : Australia (?).

508. P. splendidus, Gld., Yellow-mantled Parrakeet.

Cheeks white: head red; feathers of back edged gambogeyellow; upper tail coverts green.

Hab. : 3,7 .

509. P. ignitus, Leadbeater, Fiery Parrakeet.

Cheeks white; head red; upper tail coverts red; feathers of back edged red; under parts entirely red; bases of quills white.

Dr. Ramsay places this species (variety?) with P. eximius, which is more probably correct.

Hab. : 6, 7 .

510. P. icterotis, Temm., Yellow-cheeked Parrakeet.

Cheeks yellow; head and under parts red.

Total length, 10.5 in.

Closely related to this species is $P$. xanthogenys. One species (variety?) only is known; habitat is unknown.

British Museum Catalogue Birds, vol. xx., plate 16. Feathers of back edged with red; cheeks pale yellow.

Hab. : 9.

511. P. mastersianus, Ramsay, Masters Parrakeet.

Cheeks blue.

Total length, about 11 in.; wing, 5.8 in ; tail, 6.3 in. ; tarsus, 0.8 in. ; bill, 0.7 in.

Proc. Linn. Soc. N.S.W., vol. ii., p. 27.

Not known to the British Museum (Salvadori, 1891).

Hab. : Interior of New South Wales.

Gends-PORPHYROCEPHALUS.-Back uniform; bill longer than deep; upper mandible notched, with hook much lengthened.

512. P. Spurius, Kuhl. (Platycercus spurius), Red-capped Parrakeet. Crown deep maroon-red; lores dusky red; back and scapulars 
green; breast and abdomen violet-blue; under tail coverts red; wing coverts green ; rump yellow.

Total length, 15 in. ; wing, $6 \cdot 25$ in.

Hab. : 9.

GENUS-BARNARDIUS. - Back uniform; yellow collar round hind-neck.

513. B. barnardi, Vig. and Hors. (Platycercus barnardi), Barnard's Parrakeet. red.

Head verditer-green, with broad brown-green crescent; forehead

$$
\text { Hab. : 6, } 7 .
$$

514. B. Semitorquatus, Quoy and Gaim. (Platycercus semitorquatus), Yellow-collared Parrakeet.

Head brownish-black ; frontal band red ; abdomen green.

Hab. : 9.

515. B. zonarius, Shaw (Platycercus zonarius), Yellow-banded Parrakeet.

Head brownish-black, with no red frontal band; abdomen pale yellowish-green.

Hab : 6, 7, 9 .

516. B. occidentalis, North (Platycercus occidentalis).

Similar to B. zonarius. Light blue instead of dark blue cheeks ; yellow of abdomen much more extended, and lemon instead of yellowish-green ; narrow black band below collar absent.

Hab. : 8.

Genus-PSEPHOTUS. - Two centre tail feathers longer than following pair.

517. P. hæmatorrhous, Bparte. (P. hæmatogaster, Gld.), Crimsonbellied Parrakeet.

Abdomen red; forehead and cheeks sharply defined blue; median wing coverts red; smaller coverts verditer-green; under tail coverts red.

Hab. : 6, 7, 9 .

518. P. xanthorrhous, Gld., Yellow-vented Parrakeet.

Abdomen red; forehead and cheeks sharply defined blue; median wing coverts brownish-olive; smaller wing coverts blue; under tail coverts yellow. This species varies very much in colour and size. Hab. : 6, 7, 9.

519. P. pallescens, Gld.

Variety of P. xanthorrhous. Upper surface and breast much paler; the olive patch on median wing coverts yellower.

Hab. : 7.

520. P. pulcherrimus, Gld., Beautiful Parrakeet.

Frontal band red; rump turquoise-blue; median wing coverts with red patch ; back greyish-brown.

Hab. : 2, 3.

521. P. chrysopterygius, Gld., Golden-shouldered Parrakeet.

Frontal band pale yellow; rump turquoise-blue; median wing coverts with yellow patch.

Hab. : 1.

522. P. dissimilis, Collett.

Nearest to $\mathbf{P}$. chrysopterygius, but lacks the yellow band across forehead; lower parts verditer-blue in the male; rump bluishgreen.

Female.-Crown and forehead greyish olive-green.

Zool. Soc. Lond., part iii., p. 356.

Hab. : 1. 
523. P. multicolor, Temm., Many-coloured Parrakeet.

Rump green, with pale green cross band; frontal band bright yellow. General colour deep grass-green. Humeral feathers vary between red and yellow.

Hab. : 6, 7, 9 .

524. P. haematonotus, Gld., Red-backed Parrakeet (Red-rumped Parrakeet).

Abdomen yellow; rump red.

Hab. : 3, 6, 7 .

Genus-NEOPHEMA (Salvadori). - Four centre tail feathers about equal.

525. N. venusta. Temm. (Euphema venusta), Blue-banded Grass-

Parrakeet.

Conspicnous band of indigo-blue across forehead, not reaching behind eyes; lores and stripe behind eye yellow; shoulder and wing coverts deep blue; crown of head, back, rump, upper tail coverts, throat, chest, and flanks olive-green.

Hab. : 4,5 .

526. N. pulchella, Shaw (Euphema pulchella), Red-shouldered GrassParrakeet.

Forehead, stripe over eye, cheeks, shoulders, and lesser wing coverts rich metallic greenish-blue; a bright spot of chestnut-red at insertion of wings; chest and centre of abdomen rich yellow.

Adult female has wings duller than in male, and with no redchestnut spot on inner upper wing coverts; throat and breast yellowish-green.

Young Male.-Throat and breast yellowish-green; only a trace of red spot on inner upper wing coverts.

Hab. : 3, 6, 7 .

527. N. elegans, Swainson (Euphema elegans), Grass-Parrakeet.

Band of deep indigo-blue across forehead, bordered above by a narrow edging of light blue, which is continued over eye; lores yellow; abdomen and under tail coverts bright yellow (in some an orange spot in middle of abdomen); upper wing coverts next scrpularies olive-green; the outer ones deep blue; between olivegreen and deep blue ones there is a row of wing coverts verdigrisgreen.

$$
\text { Hab. : 3, 6, 7, } 9 .
$$

528. N. petrophila, Gld. (Euphema petrophila), Rock Parrakeet.

Frontal band deep indigo-blue; no yellow lores; all upper surface yellowish olive-green; under surface yellow.

$$
\text { Hab. : } 9 .
$$

529. N. bourkei, Mitchell (Euphema bourkei), Bourke Grass-Parrakeet All upper surface dark olive-brown; band across forehead, shoulders above and beneath, secondaries, and base of primaries deep blue.

Female has no blue frontal band.

Hab. : 6,7 .

530. N. chrysogastra, Lath. (Euphema chrysogaster), Orange-bellied Grass-Parrakeet.

Crown of head and upper surface deep grass-green; frontal band blue; lores, cheeks, and breast yellowish-green ; shoulders, some of secondaries, and outer edge of primaries deep indigo-blue; abdomen and under tail coverts greenish-yellow, the centre of abdomen having large orange spot.

In female the orange spot is smaller and duller.

Hab. : 3, 4, 5, 6, 7 . 
531. N. splendida, Gld. (Euphema splendida), Scarlet-chested GrassParrakeet.

Male.-Face and ear coverts deep indigo-blue; all upper surface grass-green ; breast rich scarlet.

Female.-Throat and breast yellowish-green.

Hab. : 6, 7, 9 .

GENUS-NANODES. - Tail feathers narrow and acuminate.

532. N. discolor, Shaw (Lathamus discolor), Swift Lorikeet.

General colour green; forehead and chin red, with yellow spot at gape ; crown of head deep blue or greenish-blue ; tips of shoulders and under tail coverts dcep red.

Hab. : 3, 4, 5, 6, 7 .

GENUS-MELOPSITTACUS.-Tail feathers acuminate.

533. M. undulatus, Shaw, Warbling Grass-Parrakeet.

General colour straw-yellow to grass-green, with black cross bands; on the cheeks an oblique band of rich blue, below which are three black circular spots, sometimes two.

Hab. : 1, 6, 7, 9.

GENOS-PEZOPORUS.-Tail long, longer than wing; nails long and straight.

534. P. formosus, Lath., Ground Parrakeet.

Adult Male.-Entirely dark grass-green; all feathers of lower breast, abdomen, and tail barred in centre alternately with yellow and black; back of head and neck green, streaked with black; touch of orange on forehead.

Total length, 12.5 in.; wing, $5 \cdot 25$ in. ; tail, $7 \cdot 75$ in.

Young wants orange band on forehead.

Hab. : 3, 4, 5, 6, 9.

GeNus-GEOPSITTACUS.-Tail shorter than wing; nails short and curved.

535. G. occidentalis, Gld., Night Parrakeet.

Upper parts olive-green; head and nape have black in middle of each feather; feathers of upper back black, with yellow spot in middle : upper tail coverts and breast with black spots and irregular bands ; abdomen and under tail coverts sulphur-yellow.

Hab. : 6, 7, 9 .

\section{ORDER-COIUIMBF.}

Rostrum swollen at the tip, convex; its basal portion has a soft skin, in which lie the nostrils, with a valve over them. The tarsi are covered fore and rear with hexagonal scales. Palate schizognathous. Nostrils schizorhinal.

\section{Sub-order-Columbæ.}

Basipterygoid processes present, and placed medially.

FAMILY-TRERONID $\AA$.

Tail with fourteen feathers. Tarsus feathered more than half its length. Soles very broad, each toe with skin expanded on the sides.

\section{Sub-Family-PTilopodina.}

Bill thin and short. Size small (less than C. livia). 
Gends-PTILOPUS.-Plumage generally green; under wing coverts not yellow.

536. P. swainsoni, Gld. (Ptilinopus swainsoni), Red-crowned Fruit. Pigeon.

Green; no yellow tinge in front of pale rosy-purple abdominal patch.

Total length, 8.5 in. ; culmen, 0.5 in. ; wing, 5.2 in. ; tail, 3 in. ; tarsus, $0 \cdot 8$ in.

Hab. : 2, 3.

37. P. ewingi, Gld. (Ptilinopus ewingii), Rose crowned Fruit-Pigeon. Green; has a distinct yellow tinge in front of pale rose abdominal patch.

Total length, 8 in. ; wing, 4.6 in. ; tail, 2.8 in. ; culmen, 0.5 in. ; tarsus, 0.6 in.

Hab. : $1,2$.

538. P. superbus, Temm., Purple-crowned Fruit-Pigeon.

Sub-gen. Lamprotreron.

Sub-gen. Lamprotreron has a broad dark blue band across breast, well defined both anteriorly and posteriorly.

Adult Male.-Crown purple-velvet; occiput and sides of head olive-green; sides and back of neck bright rufous.

Total length, 10.2 to 8.4 in. ; wing, 5.4 to 4.9 in.; tail, 3.2 to $2 \cdot 6$ in.

Adult Female.-Upper parts, including crown and hind-neck green; deep blue spot on occiput; no transverse black band below breast.

Hab. : 1, 2.

539. P. (Leucotreron) alligator, Collett.

Zool. Soc. Lond., 1898, part iii, plate 29.

Head and upper neck white; lower neck and chest whitishcinnamon; rump grey, broad whitish tips to tail feathers; lower breast, belly, and under tail coverts grey. Sexes nearly alike.

Hab.: 1.

540. P. magnifica, Temm., Purple-breasted Fruit-Pigeon.

Sub-gen. Megaloprepia.

Head and neck pale grey; all upper surface rich golden-green; median wing coverts with patch of light yellow near tip of outer webs; quills shining green; under surface of wings brown; under wing coverts yellow; line down centre of throat, middle of breast, and abdomen rich deep purple; sides of breast green. Sexes alike.

Total length, 16 in.; wing, 9 in.; tail, $7 \cdot 5$ in.; bill, 0.8 in.; tarsus, $1 \cdot 1$ in.

Hab. : 2, 3.

541. P. assimilis, Gld., Allied Fruit Pigeon.

Sub-gen. Megaloprepia.

Like P. magnifica, but sinaller.

Total length, 14 in.; wing, $7 \cdot 5$ in.

Hab. : 2.

\section{SUb-FAMILY-Carpophagine.}

Size large-more than C. livia (domestic pigeon).

GENus-MYRISTICIVORA.-General plumage white.

542. M. Spilorrhoa, G. R. Gray, Nutmeg Pigeon.

White, with creamy tinge ; winglet, primary coverts, and secondaries black; tertiaries white; terminal part of tail black; under tail coverts white, with regular subapical black spots. Sexes alike. 
Total length, 16 in. ; wing, 9 in. ; tail, 5 in.; bill, 0.8 in. ; tarsus, 1.2 in.

Hab.: 1, 2.

Genus-LOPHOL AEMUS.-Head crested.

543. L. antarcticus, Shaw, Topknot Pigeon.

Adult. - General plumage grey, darker above than below ; frontal crest grey, occipital crest rust-red ; from eye to occiput a line of black meeting behind is continued down back of neck ; feathers of chin elongated; feathers of neck and breast backled; quills black ; inner secondaries grey; tail black, crossed by grey band; iris fiery orange.

Total length, 15 in.; wing, 10.4 in. ; tail, 6 in. Hab.: $2,3,(5), 6$.

\section{FAMILY-COLUMBID A.}

Tail with twelve feathers; hind toe with the skin prominently expanded on the sides.

\section{SUb-FAMILY-CoLUMBine.}

Tail not longer than the wings.

Genos-COLUMBA.-First primary much longer than the sixth.

544. C. leucomela. Temm. (Carpophaga norfolciensis, Lath.), Whiteheaded Fruit-Pigeon.

Head, neck, breast, and abdomen. white, washed with buff; throat white; all upper surface, wings, and tail slaty-black; all feathers of back, rump, and lower wing coverts edged with purple; under tail coverts light slate colour; abdomen tinged with salmon-buff.

Total length, 16 in. ; wing, $9 \cdot 3$ in. ; tail, 6 in.

Hab. : 2, 3.

\section{SUB-FAMILY-MACROPYGIINE.}

Tail broad, and longer than the wings.

GENOS-MACROPYGIA.-Tail graduated; outer feathers less than half the length of longest.

545. M. phasianella, Temm., Large-tailed Pigeon.

General colour chestnut-brown; below cinnamon-rufous ; occiput and hind head metallic amethyst, with green reflections; a slightly vinous tinge on the crop region, where are faint bars; quills brown; under wing coverts, axillaries, and inner margin of primaries rufouscinnamon; tail rufous-brown, with black band across outer feathers; iris blue, with outer ring of scarlet.

Total length, 17 in.; wing, $7 \cdot 5$ to $7 \cdot 9$ in. ; tail, 8.5 to 9 in. Hab.: 2, 3, 4 .

\section{FAMIIIY-PERISTERID $A$ : Ground Pigeons.}

Tail from twelve to twenty feathers.

\section{Sub-FAMILY-GEopeLiñe.}

Tail twelve or fourteen feathers.

GENUS-GEOPELIA.-First primary attenuated at the tip.

546. G. Iumeralis, Temm., Barred-shouldered Dove.

Head and breast delicate grey; abdomen white ; nape rufous.

Hab. : 1, 2, 3, 4, 6, 8 . 
547. G. tranquilla, Gld. (includes G. placida, Gld.), Peaceful Dove.

Chest and neck grey, with black bands; nape not rufous; upper parts distinctly banded.

Hab.: 1, 2, 3, 4, 6 .

548. G. cuneata, Lath., Little Turtle-Dove.

Nape not rufous; upper parts grey, with no dark bands; upper wing coverts with small white spots; under surface grey.

Hab.: $1,3,6,7,8,9$.

\section{Sub-Family-Phabine.}

Metallic blue or green spots or patches on the wings.

GENUS-CHALCOPHAPS.-All wing coverts are metallic golden-green.

549. C. chrysochlora, Wagler (includes C. longirostris), Little Green

Pigeon.

Forehead white ; upper part of body bronze-grey, with three welldefined bands of grey across lower half ; primaries and secondaries bright green, developing into deep olive, each feather margined with yellow; under surface cinnamon-brown.

Total length, $9 \cdot 5$ in. ; wing, 6 in. ; tail, $3 \cdot 5$ in.

Hab.: $1,2,3$.

GENUS-PHAPS.-Tail has sixteen feathers.

550. P. chalcoptera, Lath. (Peristora chalcoptera, Swainson), Bronzewing Pigeon.

Throat white; breast vinous.

Hab. : 1 to 7, 9.

551. P. elegans, Temm. (Peristera elegans, Temm.), Brush Bronzewing Pigeon.

Throat chestnut ; breast grey.

Male.-Forehead ochreous-yellow.

Female.-Forehead whitish.

Hab. : 1, 3, 4, 5, 6, 9.

GENUS-HISTRIOPHAPS. - Tail has fourteen feathers.

552. H. histrionica, Gld. (Peristera histrionica, Gld.), Flock Pigeon (Harlequin Bronze-wing).

Adult Male.-Forehead, circle round ear coverts, and gorget snow-white ; remainder of head, throat, and ear coverts jet-black ; all upper surface, wing coverts, and two central tail feathers cinnamon-brown; breast bluish-grey; patch of metallic purple on secondaries.

Total length, 11 in. ; wing, 8 in. ; tail, $3 \cdot 75$ in.

Adult Female. -No white on forehead, which is sandy-rufous, like upper parts ; ear coverts and throat dull blackish; gorget and patch below ear coverts whitish-buff.

Hab. : $1,3,7,8$.

GENUS-PETROPHASSA.-Secondaries always more than 1 in. shorter than primaries.

553. P. albipennis, Gld., White-quilled Rock Pigeon.

Adult.--Crown of head and neck greyish-brown, each feather margined with sandy-brown; all upper surface and chest rufousbrown; throat black, with feathers tipped with white; a metallic coppery-violet spot on some wing coverts; quills dark brown; primaries with basal half pure white.

Total length, 10.5 in. ; wing, $5 \cdot 2$ in. ; tail, 4.5 in.

Hab. : 8. 
554. P. rufipennis, Collett, Rufous-quilled Rock Pigeon. Zool. Soc. Lond., 1898, part iii., plate 28.

Similar to P. albipennis.

Primaries chestnut, black tips and margins; centres to the feathers of head and neck pale grey; throat whitish.

Hab. : 1.

Genus-GEOPHAPS.-Secondaries very little shorter than primaries (less than 1 in.)

555. G. scripta, Temm., Partridge Bronze-wing Pigeon.

Adult Male.-Head, all upper surface, and chest light brown; throat and cheeks white; lores and a band from over eyes to sides of occiput and another under eyes black, also a third band passing under white ear coverts, joining another black band which surrounds throat underneath ; speculum of metallic greenish.purple on greater wing coverts.

Total length, 12 in. ; wing, 6 in. ; tail, 4.5 in.

Female alike, but smaller.

Hab. : 2, 3, 6, 7 .

556. G. smithi, Jardine and Selby, Smith Partridge-Pigeon.

Head and all upper parts brown; throat white, surrounded with narrow grey band; white line from nostrils over eyes; breast pale brown, with only a small grey patch in middle ; upper wing coverts uniform brown; outer webs of inner greater wing coverts and of tertiaries rich purple.

Total length, 11 in. ; wing, $5 \cdot 3$ in. ; tail, $3 \cdot 75$ in.

Hab. : 1, 8.

GENUS-LOPHOPHAPS.-Head crested ; tail short, nearly even.

557. L. plumifera, Gld., Plumed Bronze-wing Pigeon.

Adult Male.-General plumage pale cinnamon ; forehead and line on sides of crown grey; centre of crown and lengthened crest plumes cinnamon; throat and cheeks white; chin and gorget black; on chest a crescent of grey, with black band below ; upper wing coverts and scapularies beautifully rayed with cinnamon; abdomen, like breast, cinnamon.

Total length, 8 in. ; wing, $4 \cdot 2$ in. ; tail, $2 \cdot 6$ in.

Hab. : $1,7$.

558. L. ferruginea, Gld., Red Plumed-Pigeon.

Similar to L. plumifera.

No grey crescent on chest ; breast and abdomen uniformly cinnamon coloured (North).

Hab. : 8.

559. L. leucogaster, Gld., White-bellied Plumed-Pigeon.

Similar to above species.

Abdomen and a band before the grey pectoral band are white.

Hab. : 1, 6, 7, 8 .

GENos-OCYPHAPS.-Head crested; tail long and rounded.

560. D. Iophotes, Temm., Crested Pigeon.

Head, throat, and under part of body fawn-grey, crest a shade darker; upper part of body, back of neck, and tail brownish-grey ; greater wing coverts bronzy-green, margined with white ; inner ones metallic purple on outer webs.

Total length, about 12.5 in. ; wing, 6.75 in. ; tail, 6 in. Hab. : $1,3,6,7,8$. 
Sub-Family-Geotrygonine (Partridge-Like).

GENos-LEUCOSARCIA.-Tarsus shade longer than middle toe.

561. L. picata, Wonga-Wonga Pigeon.

Back, shoulders, and tail dark grey, with brownish tinge on wings; forehead and throat whitish; breast warm white; dark bib below throat, and a blade-like band from shoulder.

Total length, about 15 in. ; wing, $8 \cdot 5$ in. ; tail, $5 \cdot 75$ in. Hab.: 2, 3, 4 .

\section{ORDIR-GAIIINA.}

Bill short and stout; the culmen arched, and overhanging the mandible; maxillo-palatines not coalesced.

\section{Sub-order-Alectoropodes.}

The hallux raised above the level of the other toes, and its basal phalanx much shorter than that of the third toe.

\section{FAMILY-PHASIANID $Æ$.}

Nostrils never hidden by feathers; toes never pectinated.

Gends-COTURNIX.-Has ten to twelve feathers in tail ; axillaries long and pure white.

562. C. pectoralis, Gld., Stubble Quail.

Outer web of primaries uniform brown, not barred and marked with buff.

Male.-Throat dull brick colour.

Female. - Black bands on the feathers of the breast, not confluent in the median line, but separated by a buff isthmus.

Hab. : 2, 3, 4, 5, 6, 7 .

Gents-SYNCECUS.-Has ten or twelve feathers in tail; axillaries are short and grey.

563. S. australis, Temm. (includes S. sordidus, Gld.; S. diemenensis, Gld.; S. australis, Gld. ; S. cervinus, Gld.), Brown Quail.

Male. - Sides of the crown not mostly black; upper parts not blotched with black, or with the black markings present in the form of moderate bars; shaft stripes narrower, confined to the shaft itself ; chin and throat dirty white.

Female.-Sides of the crown black, or mostly black ; upper parts coarsely blotched with black; shaft stripes wider than the shafts themselves ; chest pale rufous-buff, barred all over with black.

Hab.: sordidus, 4, 6; diemenensis, 5 ; australis, 2 to 9 ; cervinus, $1,2$.

Genus-EXCALFACTORIA.-Has only eight feathers in tail.

564. E. lineata, Scopoli, sub-sp. of E. chinensis (E. australis, Gld.), Chestnut-bellied Quail (Least Swamp-Quail ; King Quail).

Male has throat black, with crescent-shaped mark of white underneath.

Female has throat and centre of abdomen buff; broad stripe over each eye sandy-buff; crown of head and all upper surface dark brown, crossed by fine bars of lighter brown, and each feather with a line of buff down centre.

Total length, $5 \cdot 25$ in. ; wing, $2 \cdot 75$ in. ; tail, $1 \cdot 1$ in.

Hab. : 2, 3, 4. 


\section{Sub-order-Peristeropodes.}

The hallux is on the same level as the other toes, and its basal phalanx as long as that of the third toe.

\section{FAMILY-MEGAPODID无. \\ Oil gland nude.}

GenUS-MEGAPODIUS. - Upper tail coverts do not extend to end of tail.

565. M. duperreyi, Less. and Garn. (includes M. assimilis, Masters ; M. tumulus, Gld.), Scrub Fowl.

Adult. - Top of head with crest of brown feathers;'back of neck and mantle grey, shading into rufescent olive-brown on middle of back and wings ; lower back and upper tail coverts dark chestnut ; tail blackish-chestnut ; chin, throat, and under parts smoky-grey.

Total length, 14 to 17 in.; wing, $8 \cdot 7$ to $10 \cdot 2$ in.; tail, 3.5 to $4 \cdot 2$ in.; tarsus, 2.5 to 3 in.

$$
\text { Hab. : 1, } 2 .
$$

GENUs-LIPOA.-Upper tail coverts extend to end of tail.

566. L. ocellata, Gld. (Leipoa ocellata), Mallee Fowl or Native Pheasant.

Top of the head covered with feathers, forming a short, thick crest ; nostrils elongate and oval ; tail long, rounded, with 16 feathers ; the longer upper tail coverts reach to the end of the tail ; a double row of large hexagonal plates down the front of the rather short tarsus.

Hab. : 6, 7, 9 .

GenUs-CATHETURUS.-Head and neck almost naked, thinly covered with hair-like feathers; a large vascular wattle at base of neck. Tail eighteen feathers; tarsi and feet rather large; fore part of tarsus covered with double row of plates.

567. C. lathami (Talegalla lathami, Gld.), Yellow-wattled Brush Turkey. Lower neck red; wattles yellow; general colour of upper parts dark brownish-black ; feathers of under parts dark brownish-grey, rather widely edged with white.

Total length, 25 in. ; wing, 12 in. ; tail, 10 in. ; tarsus, 4 in. Hab. : 2 , 3.

568. C. purpureicollis (Talegallus), Le Souëf, Purple-wattled Brush Turkey (Barnard Brush Turkey).

Similar to T. lathami; lower neck and wattles purplish-white. Female has no wattle.

Hab. : 2.

\section{ORDER-IFIMIPODII.}

Feet with three toes (except Pedionomus, which has the hallux). Maxillo palatines not coalesced with one another.

\section{FAMILY-TURNICID A.}

Button Quails, not True Quails.

\section{Genus-TURNIX.-Hind toe absent.}

569. T. maculosa, Temm. (Turnix melanotus, Gld.), Red-backed Quail (Black-backed Quail).

Tarsus longer than middle toe with claw ; centre of breast not transversely barred with black; throat never black ; sexes different ; bill slender. 
Adult female has a well-defined rufous nuchal collar; scapularies edged with golden-buff; throat and breast pale rufous; belly whitish-buff.

Adult male has no rufous collar; scapularies edged with goldenbuff ; chest buff ; upper surface greyish-brown.

Immature birds have no defined rufous collar, but most feathers of upper surface with a rufous patch at extremity; scapularies edged with buff. Hab. : 1 to $4,6,7$.

570. T. melanogaster, Gld., Black-breasted Quail.

Iarsus equal to or shorter than middle toe with claw ; bill fairly strong.

Female has chest black, many of the feathers having terminal bars of white ; upper surface umber, with here and there irregular marks of black, rufous, and white. Total length, 7.5 in.; wing, $4.4 \mathrm{in}$.

Male has chest whitish, with a wide V-shaped subterminal black mark across each feather ; upper surface as in female. Total length, $6 \cdot 3$ in. ; wing, $4 \cdot 1$ in.

Hab.: $3,7$.

571. T. varia, Lath. (T. scintillans, Gld.), Painted Quail.

Tarsus not longer than middle toe with claw ; bill slender.

Adult male has chest buff, irregularly spotted and marked with grey; no rufous nuchal collar, but otherwise the upper surface similar to that of adult female.

Adult female has chest grey, each feather with a pale buff or whitish shaft streak, becoming more or less spatulate towards tiee margin ; feathers surrounding eye black, spotted with white; has a fairly defined bright rufous nuchal collar, each feather narrowly barred with rufous. Bill stouter than in male.

Hab. : 2, 3, 4, 5 .

572. T. castanonota, Gld., Chestnut-backed Quail.

Adults have chest grey, each feather with a pale shaft streak, becoming more or less spatulate towards the margin; feathers surrounding eye black, spotted with white; bill very stout; upper surface uniform dull light red, one or two feathers of back mixed with black.

Hab. : 1, 2.

573. T. pyrrhothorax, Gld., Red-chested Quail.

Adults have chest rufous; feathers round eye black, spotted with white; upper surface stone-grey, most feathers of back with narrow transverse bars of rufous and black.

Female.-Total length, 6 in.; wing, $3 \cdot 3$ in. ; tail, 1.4 in. ; bill, 0.5 (stout).

Male.-Total length, 5.2 in. ; wing, 2.9 in. ; tail, $1.3 \mathrm{in}$.

Hab. : 2, 3, 6, 7 .

574. T. velox, Gld., Little Quail (Swift-flying Turnix).

Adults have chest dull light red, darker at sides than middle; feathers round eye dull light red, like rest of upper surface; bill very stout $(0.5$ long).

Immature birds have outer webs of primaries mottled with rufous, those of the secondaries edged and toothed with white.

Hab. : 3, 4, 6, 7, 8 .

575. T. Ieucogaster, North, White-bellied Quail.

Very similar to adult of ' $T$. velox.

The one specimen obtained showed it to have a whiter under surface.

Note, Trans. Roy. Soc. S.A., vol. xxii., p. 159.

Hab. : 7 . 
GENuS-PEDIONOMUS.-Hind toe present.

576. P. torquatus, Gld., Plain Wanderer.

Adult male differs from female in having no rust colour on nape ; collar round neck is buff and brownish, not so conspicuous, and upper surface is washed with bright buff.

Adult male, $5 \cdot 8$ in. ; wing, $3 \cdot 4$ in.

Adult female, $6 \cdot 3$ in. ; wing, 4 in.

Hab. : 4, 6, 7.

\section{ORDIR-FUICARIA (RAILS).}

Osteological characters, see Catalogue Fossil Birds, pp. 143-4, (Lydekker).

\section{FAMILY-RALLID A.}

Hind toe always raised above the level of the others; toes long and slender. Palate schizognathous.

Gends-HYPOT ENIDIA.-Culmen not so long as the tarsus.

577. H. philippinensis, Linn., Pectoral Rail.

Breast barred with white, and more narrowly with black; has a white eyebrow.

Hab. : 1 to 9.

578. H. brachypus, Swainson, Slate-breasted Rail (Lewin's Rail).

Breast uniform slate; no white eyebrow; back black, striped with olive.

Hab. : 3, 4, 5, 6, 9.

GENUS-EULABEORNIS. - Wing coverts do not hide the quills.

579. E. castaneiventris, Gld., Chestnut-bellied Rail.

Adult Female.-General colour above dark ochraceous-brown; wing coverts like back; primary coverts, quills, and tail reddishbrown; crown of head and entire sides of face clear slaty-grey; chin whitish ; pale vinous on throat ; lower throat and rest of under surface vinous-chestnut; under tail coverts, under wing coverts, and axillaries deep chestnut.

Total length, 17 in. ; culmen, $2 \cdot 2$ in. ; wing, 8.5 in. ; tail, $4 \cdot 7$ in. ; tarsus, $2 \cdot 75$ in. ; middle toe and claw, $2 \cdot 7$ in.

Hab. : 1, 2.

GENUS-RALLINA.-Secondaries do not reach to end of the primaries.

580. R. tricolor, Gray, Red-necked Rail.

Adult Male.-General colour above dark slaty-brown, with olive tinge on wings; yuills with whitish bars on inner webs; inner secondaries uniform, like back ; tail feathers blackish-brown; crown of head, hind-neck and upper mantle, sides of face and cheeks, sides of neck, fore-neck, and breast rich chestnut; throat yellowishbrown, becoming chestnut on lower throat; rest of under surface slaty-grey, with few bars of buff.

Total length, 11.5 in.; culmen, 1.3 in.; wing, 5.7 in.; tail, 2.5 in.; tarsus, 1.8 in. ; middle toe, 1.9 in.

Hab. : 2.

Genus-CREX.-Plumage striped above ; tail pointed ; retrices narrow.

581. C. crex, Sharpe, Corn Crake.

Winter Plumage.-Eyebrow, face, and breast ochreous. brown.

Summer Plumage.-Eyebrow, face, and breast grey.

[A single specimen obtained near Sydney in June, 1893.-North.]

Total length, 10 in. ; culmen, 0.85 in. ; tarsus, $1 \cdot 45$ in. 
GENUS-PORZANA.-Secondaries shorter than the primaries by length of hind toe and claw.

582. P. fluminea, Gld., Spotted Crake.

Axillaries barred with white; back streaked with black and spotted or lined with white; breast slate-grey.

Hab. : 2, 3, 4, 5, 6, 7 .

583. P. palustris, Gld., Little Crake.

Axillaries uniform, not barred with white ; back mottled; breast grey ; flanks barred.

Total length, 6 in. ; wing, $3 \cdot 2$ in.

Hab. : 2, 3, 4, 5, 6, 9 .

584. P. tabuensis, Gmelin (Porzana immaculata, Gld.), Spotless Crake. Under surface dark slate-grey; under tail coverts barred with white; axillaries uniform; back uniform rusty-brown.

Hab. : 2, 3, 4, 5, 6, 9.

GENOS-POLIOLIMNAS.-Culmen shorter than middle toe and claw; no evident frontal shield; middle toe and claw exceed tarsus; plumage variegated.

585. P. cinereus, Vieill., White-browed Water Crake.

General colour above olive-brown; crown of head dark ashy-grey ; band of white from anterior portion of cheeks, passing below eye to above ear coverts ; throat and abdomen pure white ; lower throat, fore-neck, breast, and sides of body ashy-grey ; browner on flanks.

Male.-Total length, 7.5 in.; culmen, 0.9 in. ; wing, 3.9 in.; tail, 1.8 in. ; tarsus, 1.5 in. ; middle toe and claw, $2 \cdot 1$ in.

Female.-Total length, 6.8 in. ; culmen, 0.8 in. ; wing, 3.75 in. ; tail, 1.6 in. ; tarsus, $1 \cdot 4$ in. ; middle toe and claw, $1 \cdot 8$ in.

Hab. : 1.

Gends-AMAURORNIS.-Culmen swollen at base.

586. A. moluccana, Wallace (Gallinula ruficrissa, Gld.), Rufous-tailed Moor-hen.

General colour above dark olive-brown; sides of face, cheeks, throat, and under surface of body slaty-grey; lower abdomen and vent vinous-isabelline, as also thighs.

Total length, 10.8 in.; culmen, 1.4 in.; wing, 5.75 in.; tail, $2 \cdot 2$ in. ; tarsus, $2 \cdot 2$ in. ; middle toe and claw, $2 \cdot 3$ in. Hab. : $2,3$.

Genus-TRIBONYX. - Primaries and secondaries equal in length.

587. T. mortieri, Du Bus, Native-hen.

General colour above ruddy-brown, washed with olive; under surface of body greenish-grey; on sides of body a large patch of white; under tail coverts black, the outer ones varied with white.

Total length, 14 in. ; culmen, 1.5 in. ; wing, 7.8 in. ; tail, 3.4 in. ; tarsus, $3 \cdot 25$ in. ; middle toe and claw, $3 \cdot 1$ in.

Hab. : 4, 5 .

Gends-MICROTRIBONYX.-Primaries exceed secondaries by as much as length of inner toe.

588. M. ventralis, Gld. (Tribonyx ventralis), Black-tailed Native-hen.

Under surface dark bluish-grey ; flanks have white marks ; upper surface brownish-olive.

Total length, 10.5 in. ; culmen, 1.25 in.; wing, 8.7 in. ; tail, 3.4 in. ; tarsus, 2.4 in. ; middle toe and claw, 2.5 in. Hab. : $1,2,3,4,6,7,8,9$. 
Gencs - GALLINULA.-Middle toe longer than tarsus.

589. G. tenebrosa, Gld, Black Moor-hen (Sombre Gallinule).

Dull greyish-black, except back and scapularies, which are deep brown; under tail coverts black in centre, white on sides; base of bill blood-red.

Hab. : 2, 3, 4, 6.

Gevus-PORPHYRIO.-Nostrils rounded.

590. P. bellus, Gld., Blue Bald-Coot.

Back black ; a distinct shade of verdigris-blue on throat and foreneck; thighs purplish, like flanks; bill red; knees, lower part of tarsus, and inside of feet dark grèenish-grey ; remainder of feet and legs dark green.

Total length, 17.5 in.; culmen, with frontal shield, 3 in.; wing, 10.6 in. ; tail, 3.6 in. ; tarsus, $3 \cdot 6$ in.

Hab. : 8, 9.

591. P. melanonotus, Temm. (P. melanotus), Bald-Coot.

Frontal plate, bill, legs, and feet red; no distinct patch of blue on the throat; the whole of under surface uniform blue; inner secondaries black or brown, sometimes olive-brown, like the rest of the back.

Hab. : 1 to 7.

Gexus-FULICA.-Toes lobed laterally.

592. F. australis, Gld., Coot.

Head and neck black; all upper surface greyish-black; under surface sooty-black; bill bluish-grey.

Hab. : 1 to 9.

\section{ORDIR-AIECTORIDIS.}

The angle of the mandible is always truncated; the hind toe is raised above the level of the other toes [Mesites (extra Australian) excepted].

\section{FAMILY-GRUID A.}

Palate schizognathous; nasal depression more than half as long as the maxilla; rectrices twelve.

GENUS-ANTIGONE.-Skin bare round a clear patch of ear coverts.

593. A. australasiana, Gld. (Grus australasianus), Crane (Native Companion).

Neck feathered right up to the nape ; inner secondaries grey, with white bases; general colour grey.

Total length, 42 in.

Hab.: 1 to 4,6 to 9 .

\section{FAMILY-OTIDID压.}

Bill flattened and obtuse; palate schizognathous; rectrices sixteen to twenty.

GENUS-EUPODOTIS.-Feathers of neck and fore-neck elongated ; wing three times longer than tarsus.

594. E. australis, Grey, Bustard (Plain Turkey).

A black patch across the chest or on the sides of it; greater wing coverts ashy-black, with a white spot at the end.

Total length, 48 in. ; culmen, 3 in. ; wing, 26 in. ; tail, 10.5 in. ; tarsus, 7.2 in.

Hab. : 1 to 4,6 to 9 . 


\section{ORDER-IIMICOI\#.}

Palate schizognathous. Primaries eleven; fifth secondary wanting; after shaft to the contour feathers present.

\section{FAMILY-GEDICNEMID A.}

Hind toe absent ; entirely reticulated tarsus ; nasals holorhinal.

Gends-BURHINUS.-Bill shorter than head; apical portion swollen, forming marked dertrum, and apical curve of genys ascending gently.

595. B. grallarius, Lath. (CEdicnemus grallarius), Stone Plover (Land Curlew).

General colour above ashy-grey; the crown, neck, and mantle streaked with blackish stripes, much more emphasized on back and scapulars; lower back and rump ashy-grey, streaked with blackish shaft stripes; lores, narrow eyebrow, and a spot below eye white; black and rufous line across the eye and ear coverts ; cheeks reddishbrown.

Total length, 20.5 in. ; culmen, 1.9 in. ; wing, 10.5 in. ; tail, 6 in. ; tarsus, $4 \cdot 6$ in.

$$
\text { Hab. : 2, 3, 4, 6, 7, 8, } 9 .
$$

GENUS-ORTHORHAMPHUS. $\rightarrow$ Bill as long as head; culmen perfectly straight; angle of genys very abrupt, its distance from tip of lower mandible about equal to distance from gape.

596. D. magnirostris, Vieill. (Esacus magnirostris), Large-billed Stone Plover.

Above ashy-brown, with dusky shaft lines to feathers; primaries brownish-black, with white along inner web; inner primaries pure white.

Total length, 19 in. ; culmen, 3 in. ; wing, 10.8 in. ; tail, $4 \cdot 3$ in. ; tarsus, $3 \cdot 3$ in.

Hab. : 1, 2.

\section{FAMILY-CURSORIID $A$.}

Nostrils schizorhinal ; tarsus transversely scaled in front.

GENUS-STILTIA.-Tarsus very long, the outstretched feet far exceeding tail; the first primary produced far beyond second, and extremely attenuated towards tip.

597. S. isabella, Vieill. (Glareola grallaria, Temm.), Pratincole.

Upper surface and breast light rufous, with abdomen rich chestnut. Female and young lighter, with brown spots on breast.

Total length, 9 in. ; culmen, 0.6 in. ; wing, $8 \cdot 3$ in. ; tail, 2.4 in. ; tarsus, $1 \cdot 8$ in.

Hab. : $1,2,3,7,8$.

Gends-GLAREOLA.-Tarsus rather short, outstretched feet not reaching beyond tail ; tail very strongly 'forked.

598. G. orientalis, Leach, Oriental Pratincole.

Upper surface olive; throat white, with broken ring of black beneath ; abdomen white.

Young has throat rufous and striped.

Male. - Total length, 10 in. ; culmen, 0.6 in. ; wing, $7 \cdot 3$ in. ; tail, $3 \cdot 1$ in. ; tarsus, $1 \cdot 2$ in.

Female. -Total length, 8.7 in. ; culmen, 0.7 in. ; wing, 7 in. ; tail, $2 \cdot 8$ in. ; tarsus, $1 \cdot 1$ in.

Hab. : 2, 3, 8 . 


\section{FAMILY-PARRIDA.}

Toes enormously long.

GENUS-HYDRALECTOR. - General aspect that of a rail. Toes armed with straight spur-like claws, the hind toe very long, with a claw exceeding it in length.

599. H. gallinaceus, Temm. (Parra gallinacea), Comb-crested Jacana (Parra).

Red helmet; under surface pale orange, with broad blue-black band across its middle.

Total length, 9 in. ; culmen, with frontal lappet, 1.8 in. ; wing, $5 \cdot 6$ in. ; tail, 1.6 in. ; tarsus, $2 \cdot 4$ in. ; middle toe and claw, $3 \cdot 6$ in. Hab. : 2, 3.

FAMILY-CHARADRIID $A$.

Nostrils schizorhinal ; tarsus usually reticulated, sometimes scutellated.

\section{Sub-Family-Arenarinate.}

Nasal groove not extended beyond half length of culmen; tarsus reticulated on hinder aspect, transversely scaled in front; toes without any connecting web ; no dertrum or marked swelling of bill at tips of mandibles.

Gends-ARENARIA.-Has the cleft toes of the Snipes, and the same position of nasal aperture as the Plovers.

600. A. interpres, Linn. (Strepsilas interpres), Turnstone.

Chest black; abdomen white; has a dark rump between a white lower back and white upper tail coverts.

Total length, 48 in.; culmen, 3 in. ; wing, 26 in. ; tail, 10.5 in. ; tarsus, $7 \cdot 2$ in. ; middle toe and claw, 1 in.

Hab. : 1 to 6,9 .

\section{Sub-Family-Hamatopodine.}

Nasal groove not extended beyond half length of culmen ; tarsus reticulated on both front and hinder aspect; no dertrum or marked swelling of bill at tips of mandibles.

GENUS-H EMATOPUS.-Bill thin, wedge-shaped, ending in a vertical edge; anterior toes are short, thick, edged with callosities, the outer toe joined at base to middle one by a web; hind toe wanting.

601. H. longirostris, Vieill., White-breasted Oyster-catcher.

Abdomen, rump, upper and under tail coverts and base of tail pure white ; iris crimson.

Total length, 19.5 in.; bill, 3.75 in. ; wing, 11 in. ; tarsus, 2 in.

Hab. : 1 to $6,8,9$.

602. H. unicolor, Wagler (including $H$. ophthalmicus, Castelnau and Ramsay), Sooty Oyster-catcher.

Entire plumage sooty-black ; bill orange-yellow.

Hab. : 1 to 6,9 .

\section{SUB-FAMILY - LobIVANELLINE.}

Nasal groove not extended beyond half length of culmen. Tarsus reticulated on hinder aspect, but scaly in front. Bill with dertrum always more or less conspicuous.

GENUS-ERYTHROGONYS.-Dertrum scarcely evident.

603. E. cinctus, Gld., Red-kneed Dottrel.

Thigh, knee, and for quarter-inch down tarsus pink-red, remainder of tarsus and toes bluish-lead. 
General colour above bronzy-brown; centre of lower back, rump, and median upper tail coverts blackish-brown; the sides of back and rump pure white; small patch below eye, cheeks, throat, and sides of neck pure white ; crown of head and sides of face black.

'Total length, 7.5 in. ; culınen, 0.8 in. ; wing, 4.3 in.; tail, 1.8 in. ; tarsus, $1 \cdot 6$ in.

Hab. : $1,3,6,7,8$.

Geros-LOBIVANELLUS. - Spur on the wing. Facial wattle.

604. L. lobatus, Lath., Spur-winged Plover.

Sides of chest black; a black band also crossing the hinder neck above mantle, and joining the black crown so as to interrupt the white collar; under surface white.

Hab. : 2, 3, 4, 5, 6, 7 .

605. L. miles, Bodd., Masked Plover.

Sides of chest brown; rest of under surface white; complete white collar on hind neck; no black band across neck.

Hab. : 1, 2, 8 .

\section{SUB-FAMILY-CharadRIINA.}

Nasal groove not extended beyond half length of culmen; tarsus reticulated, or with hexagonal scales both front and behind; bill with dertrum always more or less conspicuous.

GENOS-ZONIFER. - With no spur on wing, but a facial wattle present.

606. Z. tricolor, Vieill. (Sarciophorus pectoralis, Cuvier), Black-breasted Plover.

Black pectoral band; basal half of tail white; terminal half black; cheeks and throat white; sides of rump and upper tail coverts pure white.

Total length, 10.5 in.; culmen, 1.05 in.; wing, 7.4 in.; tail, $3 \cdot 2$ in. ; tarsus, $1 \cdot 9$ in.

Hab. : $2,3,4,5,6,7,9$.

GENUS-SQUATAROLA.-With no spur and no facial wattle; inner secondaries very long and pointed; the distance from shortest secondary to tip of primaries more than half length of wing; hind toe present; a black throat or breast in summer plumage; upper plumage spangled.

607. S. helvetica, Linn. (Charantrius helvetica), Grey Plover.

Adult Male in Breeding Plumage.-Axillaries black, with slight fringe of brown at tips.

Winter Plumage.-Axillaries black.

Young like winter plumage of adults, and axillaries always black.

Total length, 10.5 in.; culmen, 1.3 in.; wing, 8 in. ; tail, 3 in.; tarsus, 1.8 in.

Hab. : 3, 4, 5 .

Gends-CHARADRIUS.-As in Squatarola, but has no hind toe.

608. C. dominicus, Müll. (C. fulvous; C. xanthocheilus, Wagler), Lesser Golden Plover.

Axillaries smoky-brown at all ages.

Winter Plumage.-Buffy tint, mottled with brown. line.

Summer Plumage.-Under surface jet black, margined by white

Total length, 9 in.; culmen, 1 in. ; wing, 6.5 in. ; tail, 2.4 in. ; tarsus, $1 \cdot 6$ in.

Hab. : $1,2,3,4,5$. 
GENUS-OCHTHODROMUS.-Inner secondaries very long and pointed ; the distance from shortest secondary to the tips of primaries more than half length of wing; no black abdomen in summer, this being white; plumage of upper surface plain and mostly uniform; bill stout; culmen about equal to length of middle toe and claw; no hind toe.

609. O. bicinetus. Jardine and Selby (Ægialitis bicinctus), Doublebanded Dottrel.

Summer Plumage. - Axillaries and under wing coverts white; band of black across the fore-neck, followed by white band on the chest and by a second band of chestnut across breast.

Winter Plumage.-Axillaries white; collar of ashy-brown across fore-neck or lower throat. Hab. : 1, 2, 3, 4, 5.

610. O. geoffroyi, Wagler (Ægialitis geoffroyi), Large Sand-Dottrel.

Summer Plumage.-Axillaries and under wing coverts white; no black band on fore-neck ; forehead white, followed by narrow black band; hinder part of crown light brown, entirely surrounded by pale cinnamon-rufous, which occupies fore part of crown and extends down sides of neck round hinder neck, where it forms broad rufous collar ; across fore-neck and chest a broad band of rufous.

Winter Plumage.-Axillaries white; no collar across fore-neck, which is white, like rest of under surface ; sides of chest with brown patch.

Total length, 8.5 in. ; culmen, 1 in.; wing, 5.5 in. ; tail, 2 in. ; tarsus, $1 \cdot 4$ in.

$$
\text { Hab. : 1, 2, } 8 .
$$

611. O. mongolus, Pallas (Egialitis mongolus, Egialitis mastersi), Mongolian Sand-Dottrel.

Smaller than 0 . geoffroyi, but has a broader black line along sides of face; ear coverts entirely black; the white throat separated from rufous chest-band by a narrow black line.

Total length, $7 \cdot 5$ in. ; culmen, 0.75 in. ; wing, $5 \cdot 2$ in. ; tail, $2 \cdot 1$ in.; tarsus, $1 \cdot 2$ in.

Hab.: 1, 2.

612. D. veredus, Gld. (Eudromias veredus), Oriental Dottrel.

Summer Plumage.-Axillaries and under wing coverts smokybrown, as also quill lining; forehead broad white, and extending to sinciput; a distinct black horse-shoe below the chestnut band on chest.

Winter Plumage.-Axillaries, under wing coverts, and quill lining smoky-brown.

Total length, 8.5 in. ; culmen, 1 in. ; wing, 6.5 in. ; tail, 2.4 in. ; tarsus, $1 \cdot 7$ in.

Hab. : 1, 3, 4.

GeNuS-AEGIALITIS.-As in Ochthodromus, except that culmen is shorter-less than length of middle toe and claw.

613. E. hiaticola, Linn., Ringed Dottrel.

Throat white; no black on mantle ; a distinct white collar round hind-neck.

Hab.: 4.

614. F. ruficapilla, Temm., Red-capped Dottrel.

Throat white; no black on mantle; no white collar round hindneck; forehead white, crown rusty, and black line between; all under surface white.

Hab.: $1,2,3,4,5,6,7,9$. 
615. A. melanops, Vieill. (A. nigrifrons, Cuvier), Black-fronted Dottrel. 'Throat white ; black of upper mantle united to black ear coverts, the white collar on hind-neck being thus separated from the white of sides of neck and under parts by a complete band of black.

Hab. : 2 to 9.

616. A. cucullatus, Vieill. (Hiaticula monarcha, Geoff. ; Æ.. monachus, Geoff.), Hooded Dottrel.

Throat black, like crown and sides of face.

Young. - Has no hood, and may be known by having the feathers of the back and upper surface narrowly fringed with brownish-black.

Total length, $8 \cdot 3$ in.; culmen, $0 \cdot 7$ in. ; wing, $5 \cdot 4$ in. ; tail, 2.6 in.; tarsus, 1.05 in.

Hab. : 3, 4, 5, 9.

\section{Sub-FAmily-Peltohyatine.}

Nasal groove not extended beyond half length of culmen; tarsus transversely scaled both in front and behind; bill with dertrum always more or less conspicuous.

Genus-PELTOHYAS.-Confined to Australia.

617. P. australis, Gld. (Eudromias australis), Dottrel.

General colour above sandy-buff, mottled and streaked with dark brown centres to feathers; crown of head sandy-buff, spotted with blackish, and separated from forehead by broad black band from eye to eye ; round hind-neck a black collar, descending on to chest and skirting fore-neck in shape of a triangle.

Total length, 8 in.; culmen, 0.7 in. ; wing, $5 \cdot 3$ in. ; tail, 2.3 in. ; tarsus, $1 \cdot 3$ in.

Hab. : 4, 6, 7, 9.

SUB-FAMilY-Himantopodine.

Nasal groove not extended beyond half length of culmen; bill with no dertrum, straight or curved upwards.

Gends-HIMANTOPUS.-Toes with scarcely any web and divided to base; no hind toe.

618. H. leucocephalus, Gld., White-headed Stilt.

Hind-neck, back, and wings glossy greenish-black ; rest of plumage white.

Total length, 14.5 in. ; culmen, 2.5 in. ; wing, 9.4 in. ; tail, 2.3 in. ; tarsus, $4 \cdot 5$ in.

Hab. : 1 to 9.

GENUS-CLADORHYNCHUS.-Toes webbed; no hind toe.

619. C. leucocephalus, Vieill. (C. pectoralis, Du Bus), Banded Stilt. Body white; pectoral band chestnut; wings and abdomen black. Young.-Entirely white below.

Total length, 13.5 in. ; culmen, 2.8 in. ; wing, $7 \cdot 7$ in. ; tail, 3 in. ; tarsus, 3 in.

Hab. : 4, 5, 6, 9.

GENUS-RECURVIROSTRA.-Toes fully webbed; a hind toe; bill strongly recurved; base of genys flattened.

620. R. novæe-hollandiae, Vieill. (R. rubricollis, Temm.), Red-necked Avocet.

Head and upper neck chestnut; middle of the wing, primaries, and part of the scapularies black; the rest of the plumage white.

Total length, $15 \cdot 5$ in. ; culmen, $3 \cdot 6$ in. ; wing, 9 in. ; tail, 3 in. tarsus, $3 \cdot 3$ in.

Hab. : 2 to 9. 


\section{SUB-FAMILY-TotaNine.}

Nasal groove extending along greater part of upper mandible. Web connecting both toes with inner one.

GENUS-NUMENIUS.-Bill distinctly arched ; tarsus transversely scaled and reticulate behind.

621. N. cyanopus, Vieill. (N. australis, Gld.), Sea Curlew.

Varying brown, heavily striated and blotched; colour of crown of head similar to that of back, not showing mesial pale longitudinal band.

Female.-Total length, 24 in. ; bill, $7 \cdot 2$ in. ; wing, 12.5 in. ; tail, $4 \cdot 6$ in. ; tarsus, 3.5 in.

Male.-Total length, 21 in. ; bill, 6.8 in.; wing, 11.9 in. ; tail, $4 \cdot 3$ in. ; tarsus, $3 \cdot 2$ in.

Hab. : 1 to $6,9$.

622. N. variegatus, Salvad. (N. uropygialis, Gld.), Whimbrel.

Brown, blotched and streaked with darker brown; a central longitudinal pale band down crown, with sides of crown blackishbrown, forming a broad band along each side of latter.

Total length, 15 in. ; culmen, 3 in. ; wing, $8 \cdot 8$ in. ; tail, 3.8 in. ; tarsus, $2 \cdot 1$ in.

Hab. : 1 to $6,9$.

GENUS-MESOSCOLOPAX.-Bill distinctly arched; tarsus transversely scutellated in front and behind.

623. M. minutus, Gld. (Numenius minor, S. Müll.), Little Whimbrel. buff.

Upper surface blotched with black on buff; under surface light

Total length, 13 in.; culmen, $1 \cdot 7$ in.; wing, $7 \cdot 1$ in. ; tarsus, 1.8 in. ; tail, $2 \cdot 8$ in.

Hab. : $1,2,3,4,6,8,9$.

\section{Genos-LIMOSA.-Bill long.}

624. L. novae-zealandiae, Gray (L. uropygialis, Gld. ; sub-sp. of

L. lapponica, Linn.), Barred-rumped Godwit.

Tail regularly barred with black and white.

Adult Male,-Total length, 14.5 in.; culmen, 3.4 in. ; wing,

9 in. ; tail, $2 \cdot 9$ in. ; tarsus, $2 \cdot 2$ in.

Adult Female.-Total length, 16 in.; culmen, $4 \cdot 3$ in.; wing, $9 \cdot 5$ in. ; tail, $3 \cdot 2$ in.; tarsus, $2 \cdot 3$ in.

Hab.: 1, 2, 3, 4, 5, 6, 9.

625. L. limosa, Linn. (L. melanuroides, Gld.), Black-tailed Godwit.

Axillaries white, with or without dusky bars; tail black, with a white base to the inner quills.

Total length, 16.5 in. ; culmen, 4.4 in. ; wing, 8.8 in. ; tail, 3 in. ; tarsus, $3 \cdot 2$ in.

Hab. : 1, 2, 4.

Geros-TOTANUS. - Bill moderate, not exceeding tail in length; bill straight, the tip of upper inandible slightly decurved. Tarsus longer than midale toe and claw.

626. T. stagnatilis, Bech., Jittle Greenshank.

Under surface and rump white.

Total length, 10 in. ; culmen, 1.6 in. ; wing, 5.3 in. ; tail, 2.2 in. ; tarsus, $2 \cdot 2$ in.

Hab. : 3, 4. 
GENUS-HETERACTITIS.-Bill straight, tip of upper mandible slightly decurved; tarsus about equal to middle toe and claw; secondaries falling short of primaries by more than length of tarsus.

627. H. incanus, Gmelin (Totanus incanus), American Grey-rumped Sandpiper.

Nasal groove reaching to within the terminal third of the upper mandible and falling short of the tip by no more than 0.5 in.; tarsus reticulated behind, seldom with plates; centre of breast and abdomen thickly barred with dusky-grey, like the rest of the under surface

Total length, 9 in. ; culmen, 1.5 in. ; wing, $6 \cdot 1$ in. ; tail, 2.8 in. ; tarsus, $1 \cdot 2$ in.

Hab. : 1, 2, 3, 4.

628. H. brevipes, Pallas, Grey-rumped Sandpiper.

Nasal groove not reaching much beyond the half of the upper mandible, and falling short of the tip by 0.7 in. ; tarsus plated behind; centre of breast and abdomen white in summer plumage, and not barred.

Hab. : 2, 3.

Genus-TRINGOIDES. - Tarsus about equal to middle toe and claw. Secondaries about equal to primaries, the distance between them being much less than length of tarsus. Bill straight; tip of upper mandible slightly decurved.

629. T. hypoleucus, Linn. (Actitis hypoleucus), Common Sandpiper. Stripe above eye, throat, and abdomen white.

Adult Male.-Total length, 8 in. ; culmen, $1 \cdot 1$ in. ; wing, $4 \cdot 1$ in. ; tail, 2 in. ; tarsus, 1 in.

Adult Female.-Total length, 7 in. ; culmen, $1 \cdot 1$ in.; wing, $4 \cdot 3$ in. ; tail, $2 \cdot 4$ in. ; tarsus, $v \cdot 8$ in.

Hab. : 1 to $6,8,9$.

GENUS-TEREKIA.-Bill moderate, not exceeding tail, and with an upward curve. Both inner and outer toes united at base to middle one by a distinct membrane.

630. T. cinerea, Güldenst, Terek Sandpiper.

Upper surface brown, with darker shaft streaks; secondaries whitish ; under surface whitish.

Total length, 9 in. ; culmen, 2 in. ; wing, $5 \cdot 3$ in. ; tail, $2 \cdot 2$ in. ; tarsus, 1 in.

Hab. : 3, 4.

GeNuS-GLOTTIS.-Bill with an upward curve. Inner toe united at base by membrane to middle toe, but outer one scarcely connected. Lower mandible rises upwards from a point a little beyond half way.

631. G. nebularius, Gunner (G. glottoides, Gld.), Greenshank.

Under surface and rump white.

Total length, 13 in. ; culmen, $2 \cdot 2$ in. ; wing, $7 \cdot 2$ in. ; tail, $2 \cdot 8$ in. ; tarsus, $2 \cdot 1$ in.

Hab. : 1, 2, 3, 4, 6, 9.

Gents-BARTRAMIA. - Culmen shorter than tail. Bill distinctly thickened at end. Feathers of chin are produced forwards so as to extend beyond line of forehead. Tail peculiar in shape, being long and graduated, the outer feathers falling short of middle ones.

632. B. Iongicauda, Bechstein (Actiturus longicaudus, Newton; A. bartramius, Bparte.), Bartram Sandpiper.

Head, cheeks, breast, and tail splashed with rufous; abdomen fawn; flanks arrow-barred. 
Total length, 11 in.; culmen, $1 \cdot 1$ in.; wing, 6.5 in. ; tail, 3.3 in. ; tarsus, $1 \cdot 7$ in.

Hab. : 3, 4, 7.

\section{SUB-FAMILY-SCOLOPACINE.}

Nasal groove extending along greater part of upper mandible. Toes not webbed at all, but cleft to the base.

GENUS-LIMONITES.-Tarsus and culmen practically equal in length; tarsus about equal to middle toe and claw.

633. L. ruficollis, Pallas (Schœniclus albescens, Gld. ; Tringa albescens, Temm.), Little Stint.

Forehead and under surface white; wing coverts white-tipped.

Adult, 5 to $5 \cdot 7$ in.; culmen, $0 \cdot 7$ in. ; wing, $3 \cdot 8$ in. ; tail, $1 \cdot 7$ in. ; tarsus, 0.7 in. ; middle toe and claw, 0.7 in.

Hab. : 1 to $6,8,9$.

GENUS-HETEROPYGIA.-Tarsus and culmen practically equal ; tarsus longer than middle toe and claw.

634. H. acuminata, Hors. (Schœniclus australis, Gray ; Tringa acuminata), Sharp-tailed Stint (Marsh Tringa).

Winter Plumage.-A slight tinge of rufous on the head; throat and chest ashy-fulvous, with narrow blackish streaks.

Young have their backs blacker than in adult stage and strong rufous.

Total length, 7 in. ; culmen, $1 \cdot 1$ in. ; wing, $5 \cdot 4$ in. ; tail, $2 \cdot 1$ in. ; tarsus, $1 \cdot 2$ in.

Hab. : 1 to 9.

Genus-ANCYLOCHILUS.-Culmen longer than tarsus. Bill slender and tapering, not compressed in middle, with a sharp culminal ridge; end of bill decurved, and not broader than middle.

635. A. Subarquatus, Gmelin (Schœniclus subarquatus, Gld. ; Tringa subarquata), Curlew Stint.

Adult Plumage in Summer.-Breast and under parts rufous.

Plumage in Winter of Adult and Young.-Ashy-brown above, dark centres to feathers; rump pure white; under surface white.

Total length, $7 \cdot 4$ in. ; culmen, $1 \cdot 3$ in. ; wing, $5 \cdot 3$ in. ; tail, 1.9 in.; tarsus, $1 \cdot 1$ in. ; middle toe and claw, $1 \cdot 1$ in.

Hab. : 1 to $6,8,9$.

Genus-TRINGA.-Culmen longer than tarsus. Bill slender, with culminal ridge, but widening at end; tip straight, not decurved. Tail square, the middle feathers not prolonged. Inner secondaries falling short of primaries by more than length of tarsus.

636. T. canutus, Linn., Knot.

Adult Plumage in Summer.-Breast and under parts rufous.

Adult Plumage in Winter and Plumage of Young.-Under parts white, with dusky streaks or spots on fore-neck and chest ; upper tail coverts white, barred across with black. Culmen, 1:3 in.

Hab. : 4, 6 .

637. T. crassirostris, Temm. and Schleg., Great Sandpiper (Japanese Knot).

Under parts white, with dusky streaks or spots on fore-neck and chest; upper tail coverts white. Bill, 1.6 in.

In summer upper surface has rufous and black markings.

In winter upper surface is grey.

Hab. : $1,2,3,4,6,8,9$. 
Genos-GALLINAGO. - Tarsus not so long as middle toe and claw.

638. G. australis, Lath., Snipe.

Subterminal tail band red; crown has a long pale mesial stripe; outer or first secondaries not exceeding the primary coverts, their tips being in a line with each other; axillaries with the black and white bars about equal in length. Culmen, $2 \cdot 7$ in.

Hab.: 1 to 9.

Genus-ROSTRATULA. - Tarsus equal to middle toe and claw. Bill not perceptibly widened at end, nor pitted; tip decurved.

639. R. australis, Gld. (Rhynchæa australis), Painted Snipe.

Female.-Buff stripe down centre of head; circle round eye and stripe off it white; head and chest brown to black; under surface white.

Male.-Breast lighter and variegated.

Total length, male 9.5 in., culmen 1.7 in., wing 5.5 in., tail 1.9 in., tarsus 1.5 in.; female 9.5 in., culmen 1.7 in., wing 5.9 in., tail 1.8 in., tarsus 1.7 in.

Hab. : $2,3,4,6,8,9$.

Genos-CALIDRIS.-No hind toe. Tarsus and culmen equal in length.

640. C. arenaria, Linn., Sanderling.

Winter Plumage.-Sides of the lower back and rump white; upper tail coverts blackish, edged and tipped with white, the lateral ones entirely white; white band across wing (greater coverts); crown of head and back with tiny dusky centres; broad frontal band ; lores, eyebrows, sides of face, and under surface of body pure white.

Total length, 7 in.; culmen, 1.5 in. ; wing, 4.75 in.; tail, 1.8 in. ; tarsus, 0.9 in.; middle toe and claw, 0.9 in.

Hab. : $1,4$.

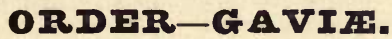

Front toes entirely connected by webs. Palate schizognathous; nasals schizorhinal. Primaries, ten large and visible, one minute and concealed. Rectrices twelve.

\section{FAMILY-LARID Æ.}

Bill without a cere. Sternum with two notches on each side of posterior margin. Claws feeble or moderate.

SUB-FAMILY - STERNiNe.

Bill straight, rather slender ; both mandibles of about equal length.

GENUS-HYDROCHELIDON.-Tail feathers rounded or slightly pointed; tail short, less than half length of wing.

641. II. Iybrida, Pall. (H. fluviatilis, Gld.), Marsh Tern.

Forehead, crown, and nape deep black; greyish-black on abdomen and flanks; bill and feet blood-red.

Total length, 11 in.; culmen, 1.4 in. ; wing, 9.5 in. ; tail, 3.8 in.; tarsus, $0 \cdot 9$ in.

Hab. : 1, 2, 3, 4, 6, 8, 9.

642. I. leucoptera, Brisson, White-winged Tern.

Summer Plumage. - Black or dark grey below.

Winter Plumage and Young.-White below; tail white.

Total length, $9 \cdot 3$ in. ; culmen, 1.1 in. ; wing, $8 \cdot 2$ in. ; tail, $3 \cdot 1$ in.; tarsus, 0.75 in. ; middle toe with claw, 1 in.

Hab. : 1, 2, in winter, extra-Australian in summer. (Doubtful visitor.) 
GeNos-GELOCHELIDON.-Outer tail feathers longest, pointed ; tarsus very long; bill robust, obtuse; tail less than half length of wing.

643. G. anglica, Mont. (G. macrotarsa, Gld.; Sterna anglica), Gullbilled Tern (Long-legged Tern).

Suminer Plumage.-Head and back of neck black.

Winter Plumage.-Head and back of neck white.

Total length, 15 in. ; culmen, 1.8 to 2 in. ; wing, 12 to 13 in. ; tail, $5 \cdot 5$ in.; depth of fork, $1 \cdot 5$ in. ; middle toe and claw, $1 \cdot 25$ in.

Hab. : 2, 3, 4, 6.

Gends-HYDROPROGNE.-Outer tail feathers longest; tarsus short; tail very short, less than one-third length of wing ; bill exceptionally stout and deep.

644. II. Caspia, Pall. (Sylochelidon strenuus, Gld.; Sterna caspia), Caspian 'T'ern.

Summer Plumage.-Head and back of neck black; forehead, crown, and nape glossy greenish-black; grey above, white beneath ; bill vermilion-red.

Winter Plumage.-Head and back of neck white; crown streaked with white.

Young.-Back and tail mottled.

Total length, 20 in. ; culmen, $3 \cdot 3$ in. ; wing, 16.5 in. ; tail, 6 in. ; depth of fork, $1 \cdot 25$ in. ; tarsus, $1 \cdot 6$ in.; middle toe and claw, $1 \cdot 7$ in. (Individuals vary in size.)

Hab. : $1,2,3,4,5$.

GENCS-STERNA.-Outer tail feathers longest, pointed; tarsus short; tail at least half length of wing; bill compressed and slender ; tarsus never exceeds the middle toe with claw.

645. S. dougalli, Mont. (S. nigrifrons, Masters; S. gracilis, Gld.), Roseate Tern (Graceful Tern).

Roseate tinge on white breast; inner webs of primaries white to the tips; upper parts very pale grey; crown black in breeding plumage; forehead black to base of culmen.

Total length, $15 \cdot 5$ in.; wing, $9 \cdot 25$ in.

Hab. : 2, 3, 9.

646. S. media, Hors. (Thalasseus torresi, Gld.), Lesser Crested Tern (Indian Tern).

Rump and tail grey, like the back; bill orange-yellow to red; crown black in breeding plumage, and forehead black to base of culmen.

Total length, 17 in. ; wing, 12 in.

Hab. : $1,2,3,4$.

647. S. bergii, Licht. (Thalasseus pelecanoides, King; T. poliocercus, Gld. ; T. cristatus, Blyth), Crested Tern (Bass Straits Tern).

Crown black in breeding plumage; front of forehead white; lores white; bill greenish-yellow; nape feathers long ; rump dark grey, like the mantle.

Total length, 20 in. ; wing, 14 in.

Hab.: $1,2,3,4,5,6,9$.

648. S. frontalis, Gray (S. melanorhyncha, Gld.), White-fronted Tern (Southern 'Tern).

Crown black in breeding plumage; front of forehead white; lores white; bill black.

'lotal length, 16 to 17 in. ; wing, $11 \cdot 25$ in.

Hab. : $1,2,3,4,5,8$. 
649. S. anæestheta. Scop. (Onychoprion panaya, Lath.), Panayan Tern. Crown black in breeding plumage; front of forehead white ; lores black ; rump and mantle umber-brown.

Total length, 14 to 15 in. ; wing, $10 \cdot 3$ in.

Under parts white in young.

Hab. : $1,2,3,4,5,6,9$.

650. S. fuliginosa, Gmel., Sooty Tern.

Crown black in breeding plumage; front of forehead white; lores

black ; rump and mantle deep black.

Total length, $17 \mathrm{in}$; wing, $11 \cdot 75$ in.

Under parts dark brown in young.

Hab. : $1,2,3,4,5,6,9$.

651. S. nereis, Gld. (Sternula nereis), White-faced Ternlet (Little Tern).

- Crown black in breeding plumage; forehead white; lores white ;

bill and feet orange-red.

Total length, 10 in.; wing, $7 \cdot 25$ in.

Hab. : 3, 4, 5, 9.

652. S. sinensis, Gmel. (Sternula inconspicua, Masters), White-shafted

Ternlet.

Crown black in breeding plumage; forehead white; lores black;

upper surface of shafts of outer primaries white.

Total length, 11 in.; wing, $7 \cdot 5$ in.

Hab. : 1, 2, 3 .

653. S. melanauchen, Temm., Black-naped Tern.

Crown always white; nape, orbits, and ear coverts black ; mantle of palest grey; wings almost white.

Total length, $13 \cdot 5$ in. ; wing, $8 \cdot 5$ in.

Hab. : 1, 2, 3.

GENUS-PROCELSTERNA.-Tail graduated, feathers pointed; outer pair of tail feathers shorter than next pair ; foot very long. In tail the second pair of retrices from the ontside the longest.

654. P. cinerea, Gld. (Anous cinereus), Grey Noddy.

General appearance grey; bill black; secondaries tipped with white; ring round eye black in front, white behind.

Total length, 11 in. ; culmen, 1.25 in. ; wing, 8.5 in. ; tail, 4.5 in.; depth of fork, 2 in. : tarsus, 1 in. ; middle toe with claw, $1 \cdot 3$ in.

Hab. : $1,2,3,4$.

Gendos-ANOUS.-Tail graduated; outer pair of rectrices shorter than next pair; fourth pair from outside the longest. Bill strong, decurved. Middle toe with claw shorter than exposed culmen.

655. A. Stolidus, Linn., Noddy.

Crown and forehead lavender-grey; upper and under surface chocolate-brown.

Total length, about 16 in. ; culmen, $2 \cdot 1$ in. ; wing, $10 \cdot 25$ to 11 in. ; tail, 6.7 in. ; tarsus, 1 in. ; middle toe, with claw, 1.5 in.

Hab : 1, 2, 3, 4, 9.

GENOS-MICRANOUS.-Tail graduated; outer pair of rectrices shorter than next pair ; third pair from outside the longest ; middle toe and claw shorter than exposed culmen; bill slender.

656. M. tenuirostris. Temm. (Anous tenuirostris), Lesser Noddy.

Crown and forehead ash-grey ; lores greyish-white ; cheeks grey ; upper and under surface chocolate-brown.

Total length, 12 in. ; culmen, 1.75 in.; wing, 8.25 in.; tarsus, 0.9 in.; middle toe, with claw, $1 \cdot 4$ in.

Hab. : 2, 3, 4, 9. 
657. M. leucocapillus, Gld. (Anous leucocapillus and A. melano. genys, Gray), White-capped Noddy.

Crown white ; lores deep black ; cheeks deep plumbeous ; general plumage sooty to bluish-black.

Total length, 13 in.; culmen, 2 in. ; wing, 9 in. ; tail, 4.8 to 5 in. ; tarsus, 0.9 in.; middle toe with claw, $1 \cdot 4$ in.

Hab. : 1, 2.

Genus-GYGIS. - Tail graduated, outer pair of rectrices shorter than next pair ; bill stout at base, pointed; plumage pure white; toes slender.

658. G. candida, Gmelin, White Tern.

Entire plumage pure white ; the second feather from the outside the longest; shafts usually brownish.

Total length, 12 to 13 in.; culmen, 1.8 in. : depth behind nostril, 0.4 in. ; wing, 9.5 ; tail, 4.2 to 4.5 in. ; tarsus, 0.6 ; middle toe with claw, $1 \cdot 1 \mathrm{in}$.

Hab. : $1,2,3,4$.

\section{Sub-FAMILY - LaRINe.}

Bill with upper mandible longer and bent down over tip of inferior one.

Genus-LARUS.-Nostrils linear or linear-ovate; tail square.

659. L. novae-hollandiae, Steph. (includes L. (Xema) gouldi, Bparte., and L. (Xema) longirostris, Masters; Bruchigavia jamesoni, Bparte.), Silver Gull.

Head, neck, tail, and under coverts white ; bill red ; inner web of first quill mostly black; wing, 12 in.; third quill with a white mirror in full adult.

Young.-Bill and feet sombre; wing coverts freckled. Hab. : $1,2,3,4,5,6,9$.

GENUS-GABIANUS. - Nostrils very small, ovate ; tail square.

660. G. pacificus, Lath. (Larus pacificus), Pacific Gull.

Head, neck, tail coverts, and under surface white; rectrices white basally, at the tips broadly banded with black on all except the outermost pair, which are white in matured birds and black on the inner webs in average examples; scapulars slightly tipped with greyish-white; secondaries with broader white tips and dark leadcoloured upper parts; primaries blackish, with white tips from the fifth upwards.

Young.-Brown and mottled or brown and maturing white in second year.

Hab. : 2, 3, 4, 5, 6, 9.

\section{FAMILY-STERCORARIID AE.}

Bill with a cere; sternum with only one notch on each side of posterior margin ; claws large, strong, hooked.

Genus-MEGALESTRIS.-Centre pair of rectrices project 0.5 in.

661. M. antarctica, Less. (Lestris catarractes, Temm.; Stercorarius antarcticus, Gray), Skua.

Plumage sooty-brown; back little streaked; bases of primaries white.

Total length, 21 to 24 in. ; culmen, $2 \cdot 2$ to 2.5 in., and depth 1 in. ; wing, 15 to 17 in. ; tail, $6 \cdot 5$ to 7 in. ; tarsus, $2 \cdot 7$ to $3 \cdot 2$ in.; middle toe with claw, $2 \cdot 9$ to $3 \cdot 2$ in.

Hab. : 2, 3, 4, 5, 6, 9. 
GENUS-STERCORARIUS. - Centre pair of rectrices project 3 in.

662. S. crepidatus, Banks (Lestris richardsoni), Richardson Skua.

Light Form.--Breast, chin, and hind-neck dull white ; forehead, crown, and abdomen brown.

Dark Form.-Washed with sooty throughout; neck pale yellow.

Total length, 20 in.; culmen, 1.5 in.; wing, 13 in. ; tail, central pair 8 in. ( 5 in. without central); tarsus, 1.7 in.; middle toe with claw, $1 \cdot 7$ in.

$$
\text { Hab. : 4, 5, } 6 .
$$

663. S. pomatorhinus, Brisson, Pomarine Skua.

Wing over 14 in.; central rectrices broad, rounded at the ends, projecting 4 in. in the adult, and twisted vertically.

Hab. : 1, 2 (winter); Siberia in summer.

\section{ORDzR-TUBIN ARzS.}

External nostrils are produced into tubes. Palate schizognathous. Nasals holorhinal. Anterior toes are fully webbed; hallux small or absent.

\section{FAMILY-PROCELLARIID A.}

Nostrils united exteriorly above culmen. Second primary the longest.

\section{Sub-Family - Oceanitine.}

Tarsus twice as long as femur.

GENos-OCEANITES.-Basal phalanx of middle toe not much flattened, less than the remaining joints and claw; claws sharp, spatulate; scutellie of front of tarsus obsolete.

664. D. oceanicus, Kuhl. (Thalassidroma wilsoni, Aucl.), Yellowwebbed Storm-Petrel (Wilson Storm-Petrel).

Adult.-Sooty.black, forehead and under surface rather paler; greater wing coverts greyish ; upper tail coverts white ; under wing coverts sooty ; tail black ; shafts of lateral rectrices towards base, and the portion of inner web adjoining, white ; bill and legs black.

Total length, $6 \cdot 8$ in. ; bill, 0.7 in. ; wing, $6 \cdot 1$ in. ; tail, side $2 \cdot 7$ in., centre $2 \cdot 5$ in. ; tarsus, $1 \cdot 4$ in. ; middle toe, $1 \cdot 1$ in.

Hab. : 3, 4, 5, 6, 9.

GRNUS-GARRODIA.-Basal phalanx of middle toe not much flattened, less than the remaining joints and claw; claws sharp, spatulate; scutellæ of front of tarsus distinct.

665. G. nereis, Gld. (Procellaria nereis, Bparte. ; Thalassidroma nereis, Gld.), Grey-backed storm-Petrel.

Head, neck, and chest sooty-grey; abdomen white; rump and edges of wing coverts grey.

Total length, $6 \cdot 7$ in.; bill, 0.6 in. ; wing, 5.2 in. ; tail, $2 \cdot 7$ in.; tarsus, $1 \cdot 2$ in.; middle toe, $1 \cdot 2$ in.

Hab. : 3, 4, 5, 6, 9.

Gends-PELAGODROMA.-Basal phalanx of middle toe not much flattened, less than remaining joints and claw; claws flattened and wide.

666. P. marina, Lath. (Procellaria fregata, Linn.; Thalassidroma marina, Less.), White-faced Storm-Petrel.

Face and under surface pure white; behind the eye a line of slate; under surface grey and brown.

Total length, 8 in.; bill, 0.9 in. ; wing, $5 \cdot 8$ in.; tail, centre $2 \cdot 75$ in., lateral $3 \cdot 1$ in. ; tarsus, $1 \cdot 6$ in. ; middle and outer toe, $1 \cdot 3$ in. Hab. : 4, 5, 6, 9. 
Gexus-CYMODROMA.-Basal phalanx of middle toe much flattened, equal to or longer than remaining joints and claw.

667. C. melanogaster, Gld. (Procellaria melanogaster, Sch.; Thalassidroma melanogaster, Gld.), Black-bellied Storm-Petrel.

Middle of abdomen sooty-black; flanks and upper tail coverts white.

Total length, 8 in. ; bill, 0.9 in. ; wing, 7 in. ; tail, 3.2 in. Hab. : 3, 4, 5, 6, 9 .

668. C. grallaria, Vieill. (Procellaria grallaria, Vieill.; Thalassidroma leucogaster, Gld.), White-bellied Storm-Petrel.

Black and white; rump and inner under wing coverts white; abdomen wholly white.

Total length, $7 \cdot 4$ in.; bill, 0.8 in.; wing, 6.5 in. ; tail, 2.9 in. Hab. : 3, 4, 5, 6, 9.

FAMILY-PUFFINID A.

Nostrils united exteriorly or nearly so above culmen; first primary the longest, or not shorter than the second.

\section{Sub-FAMily-PuFfinine.}

\section{Sides of the palate without lamellæ.}

Genos-PUFFINUS.-Tarsi distinct, compressed, and edge sharp. Nasal tube low, both wostrils visible from above, directed forwards and slightly upwards. Rectrices twelve.

669. P. chlororhynchus, Less. (P. sphenurus, Gld.), Wedge-tailed Petrel.

Tail long, cuneate; entire plumage sooty-brown.

Total length, 17 in.; wing, 11.6 in.; tail, centre rectrices 5 in., lateral rectrices $3 \cdot 3$ in. ; tarsus, 1.8 in.

Hab. : 3, 4, 5, 6, 9.

670. P. leucomelas, Temm., White-fronted Petrel.

Tail long, cuneate; under surface white; feathers of head, sides of neck, and upper plumage generally sooty, edged conspicuously with white.

Hab. : 1, 2.

671. P. assimilis, Gld. (P. nugax, Solander), Allied Petrel.

Tail rounded; under surface white.

Total length, 10.5 in.; wing, $7 \cdot 4$ in.; tail, central rectrix $2 \cdot 7$ in. lateral rectrix $2 \cdot 6$ in. ; bill, $1 \cdot 4$ in.

Hab. : 3, 4, 5, 6, 9 .

672. P. carneipes, Gld., Fleshy-footed Petrel.

Tail rounded; plumage generally sooty; bill and feet fleshy colour.

Total length, 19 in.; wing, 12.5 in.; tail, central rectrix 4.3 in., lateral rectrix $3 \cdot 7$ in. ; tarsus, $2 \cdot 25$ in. Hab. : 9.

673. P. griseus, Lath., Sombre Petrel.

Similar to P. carneipes, Gld.; plumage generally sonty ; under wing coverts ashy-white, with dark shafts; bill dark.

Wing, $12.5 \mathrm{in}$. and upwards ; central rectrices, 3.5 in. ; lateral rectrices, $2 \cdot 7 \mathrm{in}$.

Hab. : Australian seas.

674. P. gavia, Forster, Forster Petrel.

Tail rounded; under surface and under tail coverts pure white; axillaries sooty.

Total length, about 12 in. ; wing, 8 in. ; central rectrices, $2 \cdot 4$ in.; lateral rectrices, $2 \cdot 3 \mathrm{in}$; bill, 1.9 in. ; tarsus, 1.7 in. ; middle toe, $1 \cdot 8$ in. : inner toe, $1 \cdot 5$ in.

Hab. : Australian seas. 
675. P. tenuirostris. Temm. (Puffinus brevicaudus, Brandt), Shorttailed Petrel (Mutton-bird).

Plumage sooty-brown; tail rounded.

Total length, 13 in.; wing, 10.4 in. ; tail, central rectrices 3.9 in., lateral rectrices 2.8 in. ; tarsus, 2 in. ; bill, 1.8 in.

Hab. : 3, 4, 5, 6, 9

Genus-PRIOFINUS.-Tarsi distinct, compressed, and edge sharp. Nasal tubes higher than in Puffinus; nostrils united into a single opening, directed forwards. Retrices twelve.

676. P. cinereus, Gmelin (Procellaria hasitata, Kuhl.; Fulmarus gelidus, Gmelin), Brown Petrel.

Plumage greyish-brown; stripe of yellow on bill.

Total length, about 19 in.; bill, 2.4 in.; wing, 13 in. ; tail, centre 4.4 in., lateral 3.5 in.; tarsus, 2.3 in.; middle and outer toe, $2 \cdot 7$ in. ; inner toe, $2 \cdot 3$ in.

Hab. : 4, 5, 6, 9.

Genus-PRIOCELLA.-Tarsi distinct, compressed, and edge sharp. Nasal tubes higher than in Puffinus; nostrils united into a single opening, directed forwards. Tail has fourteen rectrices.

677. P. glacialoides, Smith (Fulmarus glacialoides), Silvery-grey Petrel.

Pack and wings light grey ; crown and under surface white; bill bluish, fleshy, and black.

Total length, $18 \mathrm{in}$; bill, $2 \cdot 1$ in. ; wing, 12.6 in. ; tail, central rectrix $5 \cdot 1$ in., lateral rectrix $4 \cdot 1$ in.; tarsus, $1 \cdot 8$ in.; middle and outer tnes, $2 \cdot 4$ in. ; inner toe, 2 in.

Hab.: $3,4,5,6,9$.

GENus-MAJAQUEUS.-Tarsi not compressed, more rounded on the anterior edge. Tail has twelve rectrices. Bill long, stout, not dark; unguis large; nasal tube almost united into a single opening, directed forward. Claw of hallux small.

678. M. aequinoctialis, Linn. (Fulmarus (Majaqueus) conspicillatns, Gld.), spectacled Petrel.

Chin and forehead more or less white; plumage sooty-black.

Total length, 20 in. ; wing, 15 in. ; bill, 2.6 in. ; tarsus, 2.6 in. ; tail, central rectrix $5 \cdot 3$ in., lateral rectrix $4 \cdot 5$ in.

Hab. : 4, 5 .

679. M. parkinsoni. Gray (Fulmarus parkinsoni), Black Petrel.

Plumage, including chin, sooty-black.

Total length, 18 in. ; wing, $13 \cdot 2$ in. ; tarsus, $2 \cdot 2$ in. ; tail, central rectrix $4: 3$ in., lateral rectrix $3 \cdot 6$ in.

Hab. : $4,5$.

GENUS-CESTRELATA.-Tarsi not compressed, more rounded on anterior edge. Tail has twelve rectrices. Bill stout, black, hook large ; nasal opening directed slightly upwards. Claw of hallux small.

680. AE. macroptera, Smith (Pterodroma gouldi, Hutton, and P. atlantica, Gld.), Great-winged Petrel.

Exposed portion of onter primary beneath more or less dark; entire plumage sooty-brown.

Total length, 16.5 in.; bill, 1.7 in. ; wing, 12 in.; tail, centre 4.5 in., lateral 4 in. ; tarsus, 1.6 ; middle and outer toe, $2 \cdot 2$ in. ; inner toe, 1.9 in.

Hab. : 4, 5.

681. A. lessoni, Tarnot (Pterodrona lessoni), White-headed Petrel.

Exposed portion of outer primary beneath more or less dark ; under surface of plumage more or less white; whole head, except region round eye, white. 
Total length, 18 in.; bill, 1.9 in.; wing, 12 in. ; tail, central 5 in., lateral 3.7 in. ; tarsus, 1.8 in.; middle toe, 2.4 in. ; inner toe, $2 \cdot 1$ in.

$$
\text { Hab. : 3, 4, 5, 6, } 9 .
$$

682. A. mollis, Gld. (Procellaria mollis, Gld.), Soft-plumaged Petrel.

Exposed portion of outer primary beneath more or less dark ; under surface of plumage more or less white; crown more or less dark ; upper tail coverts and under wing coverts dark.

Total length, 14 in.; bill, 1.4 in.; wing, 10.3 in. ; tail, central $4 \cdot 4$ in., lateral 3.2 in.; tarsus, 1.4 in. ; middle and outer toes, $1 \cdot 7$ in. ; inner toe, 1.5 in.

\section{Hab. : 5 (?).}

683. E. solandri. Gld. (Pterodroma solandri), Brown-headed Petrel.

Entire plumage greyish-sooty ; exposed portion of outer primary beneath more or less white towards base of inner web.

Total length, 18 in. ; bill, 1.8 in.; wing, 12 in. ; tail, centre 5 in., side $3 \cdot 8$ in.

Hab. : 3, 4, 5, 6, 9.

684. F. leucoptera, Gld. (Pterodroma leucoptera), White-winged Petrel.

Face and entire under surface white; exposed portion of outer primary beneath more or less white towards base of inner web; axillaries white.

Total length, 12 in.; bill, 1.4 in. ; wing, 8.5 in.; tail, centre $3 \cdot 8$ in., side $3 \cdot 1$ in.

Hab. : 3, 4, 5, 6, 9.

685. E. cooki, Gray, Cook Petrel.

Crown and hind-neck blackish ; much greyer than O. leucoptera, and with a slenderer and longer bill; otherwise similar.

Hab. : 2, 3, 4.

686. F. rostrata, Peale, Peale Petrel.

Upper surface blackish-brown; lower breast and abdomen white ; throat dark; tarsi flesh colour; exposed portion of the outer primary beneath more or less dark.

Total length, 14 in. ; wing, 11 in.; tarsus, 1.75 in.

Hab. : Central Pacific Ocean to Australia.

\section{Sub-FAMily-Fulmarine.}

Sides of the palate with more or less distinctly defined lamellæ.

GexUs-OSSIFRAGA.-Size very large ; nasal tube very long and stout; interramal space feathered throughout. Tail has sixteen rectrices.

687. O. gigantea, Gmelin (Procellaria gigantea, Fulmaris giganteus), Giant Petrel.

Uniform dark chocolate-brown.

Young.-Brown (or glossy black, R. H.)

Total length, 34 in.; bill, $4 \cdot 2$ in. ; wing, 20.5 in. ; tail, central

7 in., lateral 5.8 in. ; tarsus, 3.6 in. ; middle and outer toes, $5 \cdot 3$ in. ; inner toe, 4.4 in.

Hab. : 4, 5, 6, 9.

Genus-DAPTION.-Nasal tube well developed; interramal space bare. Tail has fourteen rectrices.

688. D. capensis, Linn., Cape Petrel.

Head and neck black ; under surface white ; upper surface principally white, tipped with black.

Young.-Much like adult.

Total length, 16 in.; bill, 1.7 in. ; wing, 10.5 in.; tail, 3.9 in. ; tarsus, 1.9 in.; middle and outer toes, 2.3 in. ; inner toe, $1.8 \mathrm{in}$.

Hab. : 2, 3, 4, 5, 6, 9. 
GENUS-HALOB ENA. - Nasal tube short; lamellæ of sides of palate rudimentary. First and second primaries subequal. Tail has twelve rectrices.

689. II. coerulea, Gmelin (Procellaria cœrulea, Gld.), Blue Petrel.

Lores, cheeks, and under surface white; upper surface ashy-blue.

Total length, 11 in. ; bill, $1 \cdot 4$ in. ; wing, 8.6 in. ; tail, 3.6 in. ; tarsus, $1 \cdot 3$ in. ; middle toe, $1 \cdot 6$ in. ; inner toe, $1 \cdot 3$ in.

Hab. : 4, 5, 6, 9 .

GendS-PRION.-Nasal tube short; lamellæ of sides of palate well developed. First primary the longest. Tail has twelve rectrices.

690. P. vittatus, Gmelin, Broad-billed Dove-Petrel.

Under surface white, upper bluish; bill very wide $(0.7$ to 0.8 in.) ; edges of maxilla distinctly convex; lamellæ distinctly visible when bill is shut.

Total length, 12 in.; bill, 1.5 in. ; wing, 7.6 in. ; tail, central 3.8 in., lateral 3.5 in. ; tarsus, $1 \cdot 3$ in. ; middle and outer toes, $1 \cdot 4$ in. ; inner toe, $1 \cdot 2$ in.

Hab. : 3, 4, 5, 6, 9.

691. P. banksi, Gld., Banks Dove-Prion.

Under surface white; upper bluish; bill narrower (0.5 in.); edges of maxilla distinctly convex; lamellæ only visible near rictus of closed bill.

Hab. : 3, 4, 5, 6, 9.

692. P. desolatus, Gmelin (P. turtur, Smith), Dove-like Prion.

Under surface white; upper surface blue; bill still narrower; edges of maxilla almost straight ; lamellæ invisible.

Hab. : 3, 4, 5, 6, 9.

693. P. ariel, Gld., Fairy Dove-Prion.

Upper surface blue-grey; under surface white; bill much smaller, more compressed, the hook large ; sides of maxilla straight, and the head, \&c., paler blue-grey.

Hab. : 4, 5, 6.

\section{FAMILY-PELECANOIDID $\nexists$ E.}

Nostrils distinct, opening upwards on either side of middle of base of culmen; second primary slightly the longest.

GENUs-PELECANOIDES.-Form compact ; wings feeble.

694. P. urinatrix, Gmelin (Puffinus urinatrix, Gld.), Diving Petrel.

Throat, flanks, and under wing coverts nearly pure white.

Young.-Under surface brownish-white.

Total length, 8 in.; bill, 0.9 in.; wing, 4.7 in. ; tail, 1.4 in. ; tarsus, 1 in. ; middle and outer toes, $1 \cdot 2$ in.; inner toe, 1 in.

Hab. : 4, 5, 6 .

\section{FAMILY-DIOMEDEID $Æ$.}

Nostrils lateral, opening forward, separated by the wide culmen.

GENUS-DIOMEDEA.-Sides of mandible without longitudinal sulcus (furrow). Tail short, rounded. Base of culminicorn (the horny piece encasing the culmen) joining the proximal end of the dorsal edge of the latericorn.

695. D. exulans, Linn., Great Wandering Albatross.

Bill very strong; head white; interscapular region and middle of back white; wing coverts dark slaty-black; smaller coverts nearly white.

Young. - Brown, the face white. 
Total length, 42 in.; wing, 25 in. ; bill, from gape, 7 in.

Hab. : 4, 5, 6, 9.

696. D. albatrus, Pall. (D. brachyura, Temm.), Short-tailed Albatross. Bill very strong; head buff; interscapular region and middle of back white.

Total length, 37 in.; wing, 22 in. ; bill, from gape, 6 in. Hab. : 1, 2.

697. D. melanophrys, Temm., Black-browed Albatross.

Interscapular region and middle of back slaty-black; bill of yellowish horn colour.

Total length, 30 in. ; wing, 20 in. ; tail, $7 \cdot 3$ in. ; bill, 5*2 in. Hab. : 3, 4, 5, 6, 9.

Genus-THALASSOGERON.-Sides of mandible without longitudinal furrow. Tail short, rounded. Base of culminicorn narrower than in Diomedea, and divided by membrane from the latericorn.

698. T. cautus, Gld. (D. cauta), White-capped Albatross.

Head and neck nearly pure white; bill generally pale, the sides not black and the culmen not distinctly yellow.

Total length, 35 in. ; wing, 22 in. ; tail, 9 in. ; bill, from gape, 6 in. ; tarsus, $3 \cdot 7$ in.

Hab. : 3, 4, 5, 6, 9.

699. T. culminatus, Gld., Flat-billed Albatross.

Culmen in adult bright yellow; sides of bill black; culminicorn rounded posteriorly ; lower edge of mandible yellow.

Total length, 36 in.; wing, 20 in. ; tail, $7 \cdot 7$ in.; bill, $5 \cdot 2$ in. ; tarsus, $3 \cdot 2$ in.

Hab. : 4, 5, 6, 9.

700. T. chlororhynchus, Gmelin, Yellow-nosed Albatross.

Culmen in adult bright yellow; sides of bill black; culminicorn pointed posteriorly ; base of mandible yellow, but not the lower edge.

Total length, 33 in. ; wing, $18 \cdot 8$ in. ; tail, $7 \cdot 7$ in.; bill, $5 \cdot 2$ in. ; tarsus, $3 \cdot 1$ in.

Hab. : 4, 5, 6, 9.

GENus-PHCBETRIA.-Sides of mandible with deep longitudinal sulcus (furrow); tail long, cuneate.

701. P. fuliginosa, Gmelin, Sooty Albatross.

Plumage generally sooty; a white ring (broken in front) round eye ; bill black, the groove on the mandible in life orange.

Total length, 36 in. ; wing, 19.5 in ; bill, 4.5 in. ; tail, centre rectrices 10.5 in., lateral rectrices $7 \cdot 7 \mathrm{in}$.

Hab. : 4, 5, 6. 9.

\section{ORDIR-PIATAIIF.}

Posterior angle of mandible recurved; edge of cranium above the orbits truncate, indicating the position of the nasal glands. Sternum with four posterior notches. Nasals schizorhinal ; palate desmognathous.

\section{FAMILY-IBIDID A.}

Bill much curved; nasal groove linear, and produced nearly to the tip of the bill.

GENos-IBIS. - Tarsus reticulated anteriorly, with many hexagonal scales. Webs of feathers of inner secondaries disconnected, ornamental.

702. I. molucea, Cuvier (Threskiornis strictipennis, Gld.), White Ibis. General appearance white; fore-neck plumed; primaries with a broad tip of blue-black; inner secondaries barred and mottled with purplish-black; head and neck bare. 
Young.-Head and neck feathered, and streaked with black and white.

$$
\text { Hab. : 1, 2, 3, 4, 6, 7, } 8 .
$$

GENOS-CARPHIBIS-Head and throat bare. Hind-neck feathered to nape. Long stiff yellow shafts on the fore-neck.

703. C. Spinicollis, Jameson (Geronticus spinicollis), Straw-necked Ibis.

General colour above black, glossed with steel-green on upper back and mantle, and purplish on scapulars and wings; the long upper tail coverts and tail feathers white; wing coverts and quills black, barred with bronze externally; centre of neck white, with straw-coloured plumes on each side ; breast and abdomen pure white.

Young.-Head and neck feathered; back sooty-black; under surface white.

Total length, male 29 in., female 27 in.

Hab.: 1, 2, 3, 4, 6, 7, 8 .

Gends-PLEGADIS.-Throat feathered as far as the interrainal space; chin only bare ; lores bare ; cheeks partly bare.

704. P. falcinellus, Linn. (Ibis falcinellus), Glossy Ibis.

Summer Plumage - Head, neck, mantle, scapulars, and under surface deep rufous.

Winter Plumage.-Head and neck streaked with black and whitish ; no chestnut as well on mantle and scapulars.

Young.-Similar to winter plumage.

Hab. : 1, 2, 3, 4, 6, 7 .

\section{FAMILY-PLATALEID $Æ$.}

Bill flattened, narrow in the middle, and widening out into a spoon-shaped end.

Genus-PLATALEA.-Head partly bare, oricular orifice covered with plumes. Nostrils elongated and in a shallow depression.

705. P. regia, Gld. (P. melanorhyncha), Black-billed Spoonbill (Royal Spoonbill).

Whole of plumage white; crest on crown; a tinge of sandy-buff on fore-neck ; bill, forehead to behind the line of the eye, fore part of cheeks, and upper throat black; yellow spot above the eye.

Young. -No crest ; white.

Hab. : 1, 2, 3, 4, 6, 7, 8 .

GENUS-PLATIBIS.-Nostrils elongate, and situated in a deep depression, with lateral ridges. Inner secondaries with decomposed plumes, as in an Ibis.

706. P. flavipes, Gld. (Platalea flavipes, Gld.), Yellow-billed Spoonbill. General colour white; dense tuft of fore-neck feathers straw. colour; bill, forehead, upper throat, and region in front of and behind the eye yellow; the yellow of face divided from plumage by narrow black line.

Young.-No ornamental plumes on fore-neck.

Hab.: 2, 3, 4, 6, 7.

\section{ORDIR-IERODIOTIS.}

Hallux free, not united to the other toes by a web; nasals holorhinal; palate desmognathous.

\section{FAMILY-ARDEID A.}

Hind toe on the same plane as the other toes. Bill rounded or ridged; bill notched, with no dertral hook at the end. Outer toe with a broad basal web, obsolete at base of inner toe; middle claw pectinated. Loral space bare ; powder down patches present. 
GENUS-ARDEA.-Edges of mandibles distinctly serrated ; head crested ; nape feathers elongated and ornamented ; plumes of fore-neck not disintegrated; no dorsal train.

707. A. sumatrana, Raffles (A. rectirostris, Gld.), Great-billed Heron. Breast, abdomen, and under tail coverts slaty-grey ; ornamental plumes on chest pearly-grey; head and chest feathers ashy-grey or slate colour; the ornamental dorsal plumes pearly-grey.

Young has abdominal feathers rust.edged.

Total length, about 50 in. ; culmen, 6.5 in. ; tarsus, 8 in. Hab. : 1, 2, 3.

708. A. cinerea, Linn., Grey Heron.

General colour grey : crown of head white, black on the sides and the nape crest; thighs white; edge of wing white or creamywhite.

Total length, male about 36 in. ; female about 39 in.

Hab.: $3,(6), 7$.

GENUS-MESOPHOYX.-Edge of mandible distinctly serrated; head crested, without ornamental plumes; fore-neck with disintegrated plumes; an immense dorsal train.

709. M. plumifera, Gld. (Herodias egrettoides, Gld.; Herodias intermedia, Ramsay; Herodias melanopus, Ramsay, nec Wagler), Plumed Egret.

Plumage pure white; bill, orbits, and bare skin of face yellow; feet and lower part of tarsi black, upner part of tarsi inclining to flesh colour; a distinct loral black patch.

Total length, 25 in.; culmen, 3.1 in ; wing, 11 in. ; tail, 5.4 in. ; tarsus, 4.05 in. ; middle toe and claw, $37 \mathrm{in}$.

Hab. : 1, 2, 3, 4, 6, 8, 9 .

GENUS-HERODIAS.-Edge of mandible not serrated; no crest plumes ; a well-developed dorsal train.

710. H. timoriensis, Less. (H. alba, nec Linn., Gould's Handbook, ii., p. 301 ; see also British Museum Catalogue Birds, xxvi., p. 270. Appendix), White Egret.

Plumage white; bill black in summer, yellow in winter; lores and orbits pale green; feet blackish, tibiæ paler; train of plumes (decomposed feathers) short, just passing tail.

Measurements of Australian race :-Total length, 30 in. ; culmen, 4.4 in. ; wing, 15 in. ; tail, 6.3 in. ; tarsus, $5 \cdot 2$ to $6 \cdot 4$ in.

Hab. : 1 to 9 .

Genos-NOTOPHOYX.-Tarsus not twice the length of outer toe and claw. A full crest, but no elongated pair of nape plumes.

711. N. novae-hollandiae, Lath. (Ardea novæ-hollandiæ), Whitefronted Heron.

Plumage in general slaty-grey; forehead, eyebrow, and throat white ; dorsal plumes grey; sides of chest vinaceous ; breast plumes are lanceolate.

Hab. : 1 to 9.

712. N. pacifica, Lath. (Ardea pacifica, Lath.), White-necked Heron.

Upper surface glossy olive-green; breast and abdomen with large lanceolate streaks of white; a large maroon patch of feathers on the side of the chest; head and neck vinaceous or white, with some black markings on the lower throat. Sometimes the neck is wholly white.-Gould.

Hab. : 1 to 9 . 
713. N. flavirostris, Sharpe (Herodias picata, Gld.; Demiegretta picata), Pied Egret.

Crest, crown of head, and sides of face black ; throat, cheeks, and neck white; bill, legs, and feet greenish-yellow.

Total length, 19 in. ; culmen, 2.5 in. ; wing, 8.7 in. ; tail, 3 in. ; tarsus, $2 \cdot 8$ in.

Hab. : 1 .

714. N. aruensis, Gray, Allied Egret.

Whole head and neck white; under surface white; upper surface slaty-brown; bill yellow. This was considered by Gould (Handbook) to be the young of $\mathrm{N}$. flavirostris (H. picata, 713).

Hab. : 1.

Gends-GARZETTA. - No crest on head but with drooping head plumes ; breast with lanceolate white plumes.

715. G. nigripes, Temm. (Herodias garzetta, Ramsay ; H. melanopus, Gld., nec Wagler), Little Egret.

Plumage white; plumes suspended from the nape (two elongated); plumes upon back and breast ; feet and toes totally black. Winter plumage is without the plumes and base of culmen more yellow.

Total length, about 22 in. ; culmen, 3.4 in.; tarsus, 37 in. ; wing, $10 \cdot 7$ in. ; middle toe and claw, $2 \cdot 7$ in.

Hab. : 1, 2, 3.

Gents-DEMIEGRETTA.-Bill without serrations ; culmen longer than tarsus; tarsus longer than middle toe.

716. D. sacra, Gmelin, Reef Heron.

Includes Herodias asha, Gould's Handbook, ii., p. 305 (nec Sykes); Demiegretta grayi, Gould's Handbook, ii., p. 305 ; D. asha, Ramsay's Tab. List, p. 21 ; D. jugularis, Gld.

Demiegretta asha of Sykes equals Lepterodius asha, an extraAustralian species.

General plumage dark slate colour; head crested, a pure white streak down centre of the throat.

Total length, 23 in.; culmen, $2 \cdot 8$ in. ; tarsus, $2 \cdot 9$ in.

Hab. : 2, 3, 4, 5 .

Genus-NYCTICORAX.-Tarsus about equal to middle toe and claw; bill higher than broad.

717. N. caledonicus, Gmelin, Night Heron.

General colour nankeen (light chestnut); two or three long white nuchal plumes; eyebrow white; thighs white, faintly flushed with rufous.

Hab. : $1,2,3,4,5,6,8$.

GeNus-BUTORIDES.-Culmen longer than tarsus; ornamental nape and dorsal plumes lanceolate.

718. B. stagnatilis, Gld. (B. macrorhyncha, Gld. ; B. javanica, Ramsay's List, p. 21, and Gould's Handbook), Thick-billed Bittern.

B. javanica, Hors., is considered by Dr. Sharpe an extra-Australian bird.

Upper surface slaty-grey; abdomen rusty-brown; throat and cheek stripe light brown.

Total length, 17 in.; culmen, $2 \cdot 8$ in. ; tarsus, $1 \cdot 9$ in.

Young. - Throat white, mottled with sandy spots as on wing coverts. The colour of the soft parts varies with the season.

Hab. : 1, 2, 3. 
Genus-ARDETTA.-Tail feathers ten; bill serrated. Tibio-tarsus feathered right down to the heel ; middle toe and claw about equal in length to tarsus.

719. A. sinensis, Gmelin, Chinese Heron.

Back and scapulars uniform earthy-brown ; crown of head black ; wing coverts light clay colour; neck frill vinaceous, also sides of face. Female more rufous above ; sides of face yellowish-buff.

Young has wing coverts broadly centred with dark brown, and crown streaked; under surface of body much more distinctly streaked.

Total length, $15 \cdot 5$ in. ; culmen, $2 \cdot 1$ in. ; tarsus, 2 in. Hab. : 1 .

720. A. Dusilla, Vieill. (A. minuta, Ramsay's Tab. List), Little Bittern. (A. minuta, Linn., is considered extra-Australian.)

Bill, feet, and space round the eye yellow; general appearance yellowish-rufous; back and scapulars black; neck full; sides of face and eyebrows bright chestnut.

Total length, 10 in. ; culmen, $1 \cdot 8$ in. ; tarsus, 1.6 in. Hab. : 1, 2, 3, 4, 6 .

GeNts-DUPETOR.-Bill short and thick ; culmen lower than the tarsus ; tarsus equals middle toe and claw.

721. D. gouldi, Bparte. (Butorides flavicollis, Gld.), Black Bittern.

(D. flavicollis, Lath., not Australian.)

Upper surface dark slaty-grey ; back and scapular feathers hoary and glossed; wings and tail black; row of feathers down throat are black ; fore-neck reddish-brown ; abdomen brown.

Total length, male 24 in., tarsus 2.6 in.; female 21 in., tarsus $2 \cdot 6$ in.

$$
\text { Hab. : 1, 2, 3, 4, 6, 8, } 9 .
$$

Genus-BOTAURUS.--Hind claw very long, nearly equal to hallux in length. Culmen about equal to inner toe with claw ; bill serrated.

722. B. poeciloptilus, Wagl. (B. australis, Gld.), Bittern.

Head and ruff on sides of neck smoky-brown; mantle and scapulars uniform black; sides of chest have black-centred feathers; space round eye and feet pale green; reddish bands on fore-neck.

Young.-More uniform reddish tint ; quills mottled and barred. Hab. : $1,2,3,4,5,6,9$.

\section{FAMILY-CICONIID A.}

Hind toe elevated above the plane of the other toes; no powder down patches; bill not hooked at the tip; both toes webbed at the base, the outer one especially ; no pectination on middle claw.

\section{SUB-FAMily-CiconiIna.}

The lower mandible has the genys recurved, never decurved.

GENUS-XENORHYNCHUS.-Culmen very long, about equal to the tarsus.

723. X. asiaticus, Lath. (Mycteria australis), Black-necked Stork (Jabiru).

Plumage above white; under surface white; head and neck covered with metallic bluish glossy plumes; legs and toes coral red.

Tarsus, 11 in. ; culmen, $11 \cdot 5$ in.

Hab. : 1, 2, 3, (7), 8. 


\section{ORDER-STEGANOPODES.}

Hallux united to the other toes by a web ; nasals holorhinal; palate desmognathous.

\section{FAMILY-PHALACROCORACID E.}

Tail rounded or cuneate. Webs between toes not emarginate, or only slightly so. Bill subcylindrical and hooked at the extremity, or elongate and pointed; nostrils nearly obsolete.

\section{Sub-Family-PhalaCrocoracina.}

Bill subcylindrical, and strongly hooked at the extremity; cutting edges of mandibles entire.

GENUS-PHALACROCORAX.-A long, narrow groove on each side of bill, dividing at nail ; cutting edges of mandibles entire. A gular pouch, naked anteriorly. Neck long and sinuous. Quills stiff. Tail wedge-shaped or rounded. Middle toe has pectinated claw.

724. P. carbo, Linn. (Graculus novæ-hollandiæ, Steph. ; P. novæhollandiæ, Steph.), Black Cormorant.

Colour of plumage black, glossed with dull green; a large white patch on flanks ; wing coverts and scapulars bronze-brown, margined with dark steel-blue; feathers bordering the naked throat pure white. Winter plumage lacks the white markings of flanks.

Total length, about 35 in.

Hab. : $2,3,4,5,6,9$.

725. P. sulcirostris, Brandt (Graculus stictocephalus, Bparte.; P. stictocephalus, Bparte.), Little Black Cormorant.

Plumage brownish-black, with a dull oily-green colour; some white plumules scattered upon the neck and upon each side of the head above the eye; back and scapulars with ash middles, each feather margined by black band.

Total length, about 25 in.

Hab. : 2, 3, 4, 6, 7, 9.

726. P. gouldi, Salvad. (Graculus leucogaster, Reich. ; P. leucogaster, Gld.), White-breasted Cormorant.

Crown, upper surface, and flanks black, glossed with dull steelblue; sides of the head, chin, and under parts white; naked skin at base of bill and round eye purple; scapulars bronze green, with very narrow steel-blue margins ; below commissure of bill is white.

Culmen, 1.8 to 2 in.

Hab. : 2, 3, 4, 5, 6, 9.

727. P. hypoleucus, Brandt (Graculus varius, Finch ; P. varius, Gld.), Pied Cormorant.

(P. varius, Gmelin, is a New Zealand bird.)

Similar to P. gouldi, culmen longer, 2.7 in. ; no feathers below the commissure of the bill; bare space in front of eye bright orange; eyelid and naked skin below the eye indigo-blue.

Hab. : 3, 4, 6, 9.

725. P. melanoleucus, Vieill. (Graculus melanoleucus), Little Cormorant.

Crown, back of neck, and upper surface shining black ; under tail coverts and vent brownish-black; all under surface white, including chin and throat; lateral manes.

Breeding plumage has some white feathers on head and neck.

Total length, 23 in.; culmen, $1 \cdot 2$ in.

Hab. : $2,3,4,5,6,9$. 


\section{SUb-FAmily-Plotina.}

Bill elongate and pointed; cutting edges of mandibles serrated. Body nearly uniformly clothed with soft and small contour feathers.

GENos-PLOTUS.-Bill compressed, straight and pointed; no lateral groove; cutting edge of mandible along the terminal half serrated. Neck very long and slender.

729. P. novae-hollandiae, Gld., Darter.

General plumage glossy black ; a white stripe down a part of neck below the eye; a white line of feathers borders the bare throat.

Male.-Neck and under parts black; a long patch of chestnut on the base of fore-neck.

Female.-Fore-neck and under parts white. Hab. : $1,2,3,4,6,7$.

\section{FAMILY-SULID $A$.}

Tail wedge-shaped. Web between toes not emarginate, or imperfectly so. Bill subcylindrical and pointed; no external nostrils.

Gexus-SULA.-Bill stout, and tapering towards the extremity, never hooked; nostrils quite closed in adult. Chin and upper part of throat naked.

730. S. serrator, G. R. Gray (Sula australis, Gld.), Gannet.

Plumage mostly white; head and neck washed with yellowishbuff; naked band on throat about 2 in. long; two middle pairs of tail feathers brown, four outer pairs white.

Young. - Sooty. brown and spotted white.

Total length, about 36 in. ; wing, $1 \cdot 8$ in. ; tarsus, $2 \cdot 2$ in.

Hab. : $3,4,5,6,9$.

731. S. cyanops, Sundevall (S. personata, Gld.), Masked Gannet.

Adult.-Pure white, except primaries, secondaries, coverts, and tail, which are brown; the basal parts of tail and quills are white ; bill pale green to horn-blue; gular and orbital skins are bluishblack. Tarsus, $2 \cdot 3$ in.

Young. - Head, neck, and back brown mixed with white.

Nearly adult specimens have lesser coverts, lower back, and rump mixed with brown, otherwise they are like adult.-E. A. Butler.

$$
\text { Hab. : 1, 2, 3, (4). }
$$

732. S. piscator, Linn., Red-legged Gannet.

Mostly pure white, including the tail ; outer webs of flight feathers greyish or blackish in new moult birds; naked skin round eye blue ; legs vermilion; tarsus, $1 \cdot 4$ in.

Young birds are mostly all brown to their first moult; in second year head, neck, and scapulars are white, and middle tail feathers and back are brown.

Hab. : 1, 2.

733. S. sula, Linn. (S. leucogastra, Bodd. ; S. fiber, Gld.-immature), Brown Gannet (Booby).

All upper parts, fore-neck, and chest sooty-brown ; breast, axillaries, and remaining under parts white.

Total length, about 28 in.

Young birds are brownish beneath, or the same mixed with white. Hab. : 1, 2. 


\section{FAMILY-FREGATID $Æ$.}

Tail deeply forked; webs between toes deeply emarginated.

GENUs-FREGATA.-Bill long and strongly hooked at extremity ; nostrils basal and linear and in a groove. A large naked gular pouch. Wings long and pointed; tarsus short and feathered.

734. F. aquila, Linn. (Tachypetes aquila, Vieill. ; T. minor, Gmelin), Frigate-bird.

Male.-Plumage of upper surface glossy greenish-black; breast and sides black; no white patch on flank. Culmen, 3.6 to 4.4 in. ; wing, 20.5 to 25.8 in.

Female. - Upper surface without glossy green; breast and sides white ; no white neck collar at rear. Culmen, $4 \cdot 3$ to $5 * 2$ in.; wing, 22.9 to $26 \cdot 7$ in.

Young.-Head, neck, upper chest, and middle of abdomen white, brown beyond.

Hab. : 1, 2, (4).

735. F. ariel, Gld. (Attagen minor, Ramsay's Tab. List; Tachypetes minor, nec Gmelin, Gould's Handbook, ii.), Lesser Frigate-bird.

Male.-Upper surface greenish-black (oil-green and metallicgreen); breast and sides black; a white patch on each flank. Culmen, $2 \cdot 8$ to 3.5 in. ; wing, $19 \cdot 2$ to 21 in.

Female. - Little trace of metallic gloss ; breast and sides white ; a white collar at rear of neck. Culmen, $3 \cdot 2$ to $3 \cdot 6$ in. ; wing, 20 to 20.8 in.

Young.-Head and neck white ; breast, sides of abdomen, lower neck and upper parts brown; middle abdomen and flanks white.

Hab.: $1,2$.

\section{FAMILY-PHAËTHONTID $A$.}

Webs between toes only slightly emarginate. Middle tail feathers greatly produced. Bill compressed and pointed; nostrils clear and linear.

GENUS-PHAETHON.-Bill compressed, pointed, slightly curved all over ; nostrils linear and distinct. Middle pair of tail feathers greatly attenuated.

736. P. rubricauda, Bodd., Red-tailed Tropic-bird.

General colour white, with roseate tinge upon it; a black line passes through eye and ends in a crescent above the gape; outer primaries have their outer webs white to the base; the very long slender middle tail feathers carmine, with black shafts ; tail, 17 to 18 in. ; tarsus, $1 \cdot 2$ in.

Young.-Barred with black upon the upper surface. Hab. : 1, 2, (4).

737. P. lepturus, Daudin (P. candidus, Temm.), White-tailed Tropicbird.

Plumage white; outer primaries have most of the outer webs black; black on outer web of outer primaries stops at an inch or more from tip; the third primary nearly as widely tipped with white as the first; the long tail feathers whitish; bill yellow at terminal one-third.

Young.--Upper surface barred.

Hab. : 2, 3.

\section{FAMILY-PELECANID $A$.}

Bill long and flattened, with external nostrils.

GENUS-PELECANUS.-Bill very long, broad, and flat; a median bar runs the length of it. A very large distensible gular pouch. Wings large; tail small. 
738. P. conspicillatus, Temm., Pelican.

Plumage white; quills, their coverts, scapulars, sides of rump, and tail black; naked skin round eye is surrounded by feathers.

Total length, about 60 in. ; culmen, 17 to 18 in. ; wing, 24 to 25 in. ; tail, 7.5 in. ; tarsus, 5 in.

Hab. : 1 to $7,9$.

\section{ORDFR-PYGOPODPS.}

Wing feathers developed into remiges. Cnemial process of tibia produced forward in a remarkable degree. Palate schizognathous.

\section{FAMILY-PODICIPEDID $A$.}

Hallux raised above the level of the other toes; toes provided with wide lateral lobes, united at the base. Tail vestigial.

Gexus-PODICIPES. - Culmen short; secondaries, if any, very little shorter than the primaries.

739. P. nova-hollandia, Steph. (P. gularis, Gld.), Black-throated Grebe (Dabchick).

Plumage above sooty-black; grey on back; chin and throat black ; fore-neck smoky-brown; a chestnut band along side of neck from the eye.

Total length, 9.5 in. ; tarsus, 1.4 in.

Adult out of breeding season has chin, throat, and under parts white.

Young. - Sides of neck and head striped with white.

Hab. : 1 to 8 .

740. P. poliocephalus, Jardine and Selby (P. nestor, Gld.), Hoaryheaded Grebe.

Sides of head have hair like feathers in breeding season; breast and abdomen silvery-white; all inner primaries and secondaries almost pure white.

Winter Plumage. - No head ornament, and crown of head and hind-neck greyish-brown.

Total length, $9 \cdot 5$ in. ; tarsus, $1 \cdot 5$ in.

Young similar to winter bird.

Hab. : $3,4,5,6,7,9$.

741. P. cristatus, Linn., Tippet Grebe.

Feathers on sides of crown form a long double crest; ruff of black plumes on neck; colour above dark ashy-brown; under parts silverywhite; shoulder feathers nearly pure white; lesser wing coverts form a wide white band along edge of wing.

Winter Plumage.-Head, neck, and back ashy-brown; no crest.

Total length, about 20 in.

Young.-Similar to winter plumage, with brown stripes on head and neck.

Hab. : $3,4,5,6,7$.

\section{ORDエR-IMIFNNIS.}

Bill never hooked. Nostrils pervious, holorhinal. Palate schizognathous.

GeNus-CATARRHACTES - Bill moderately long and very stout, the culminicorn being divided from the latericorn by a deep groove, which is much swollen towards the base; feathering at the angle of the gape leaving the tomia and the greater part of the base of the mandibles exposed. A superciliary band of more or less golden feathers. 
742. C. chrysocome, Forst. (Eudyptes saltator, Sharpe), Crested Penguin.

General colour dark slate; crown of head black; longest crest feather about 3.5 in., the crest feathers being yellow and black; forehead uniform black, the yellow not. being united.

Total length, about 25 in.

Young.-Crest is indicated by a yellowish-white line; chin ashywhite.

Hab. : 5, (6).

Genus-EUDYPTULA.-Tail very short, and almost concealed by the long upper tail coverts. Groove dividing the culminicorn from the latericorn inconspicuous; basal part of mandibles entire.

743. E. minor, Forst. (E. undina, Gld.; Spheniscus undina, Gld.), Little Penguin.

Above slaty-blue, each feather with a brownish-grey base and black shaft; all the ventral surface pure white; flippers have their inner margins narrowly bordered with white.

Total length, about 16 in.; exposed culmen, ' 1.4 in.; gape to tip, $1 \cdot 75$ in. ; nasal opening to tip, $1 \cdot 2$ in.

Hab. : (3), 4, 5, 6, 9.

ORDIR-CEFNOMORTI\#.

Palate desmognathous. Young covered with down, and able to run or swim in a few hours after hatching.

\section{Sub-order-Anseres.}

Tarsus about the length of the femur, reticulated at back and generally in front. Bill straight, always with a distinct nail at the tip of the upper mandible.

FAMILY-ANATID $A$.

Margins of bill laminated.

SUB-FAMili-CyGNine.

Hind toe lobed. Neck very long, as long as or even longer than the body.

GENuS-CHENOPIS.-Predominent colour black.

744. C. atrata, Lath. (Cygnus atratus), Black Swan.

Primaries and secondaries pure white; tertiaries and scapulars crisp; bill pinky-scarlet, with white bar near tip.

Hab. : 2 to $6,8,9$.

\section{Sub-FAmily-Anseranatine.}

Hind toe not lobed. Feet semi-palmated.

Genus-ANSERANAS.-Plumage black and white.

745. A. Semipalmata, Lath. (A. melanoleuca, Lath.), Pied Goose.

Head, neck, mantle, wings, tail, and thighs black ; back, rump, breast, abdomen, upper and under tail coverts, scapulars, and smaller upper wing coverts white.

Hab.: 1, 2, 3, 4, (5), 6, 7, 8. 


\section{Sub-Family-Plectropterine.}

Hind toe not lobed, rather long. Feet palmated. Tail feathers rather long, broad, rounded at top. Upper parts mostly glossy.

GENUS-NETTOPUS. - Bill not so long as double its depth.

746. N. pulchellus, Gld., Green Goose-Teal.

Upper surface glossy green; under surface white; sides with crescent-like bands; neck dark green in male, banded with white and green in female.

Total length, 13.5 in. ; culmen, 1 in.; wing, 7 in. ; tail, 3 in. ; tarsus, 1 in.

$$
\text { Hab. : 1, 2, } 8 .
$$

747. N. albipennis, Gld. (N. coromandelianus, Gmelin), White-quilled Goose-T'eal.

Upper surface glossy green; under surface white; sides waved with narrow grey lines; neck white. Male with broad black band across breast ; female with no broad black band across breast, but the neck with narrow black bands all round.

Total length, 13 in. ; culmen, 0.9 in. ; wing, 7.5 in. ; tail, 3.4 in. ; tarsus, 1 in.

$$
\text { Hab. : 2, } 3 .
$$

Sub-FAMiLY-Cereopsine.

Cere of the bill much developed.

GENUS-CEREOPSIS. - Face wax-like; sternum imperceptibly keeled.

748. C. nova-hollandiae, Lath., Cape Barren Goose.

Crown of head whitish; general plumage brownish-grey; some wing coverts and scapulars with a spot near tip ; cere lemon-yellow. Hab. : 4, 5, 6, 9.

\section{Sub-Family-ChenonetTin}

Hind toe very narrowly lobed. Bill rather short and goose-like.

GENUS-CHENONETTA.-Tertials long and narrow ; upper wing coverts grey.

749. C. jubata, Lath. (Branta jubata), Maned Goose (Wood Duck).

Male.-Breast grey, each feather broadly tipped with greyishwhite, and black spotting on each side, all appearing as mottled; lower part of back, rump, upper and under tail coverts and abdomen deep glossy black; speculum glossy green across secondaries. Culmen, 115 in.

Female.-Side of face speckled white; abdomen and under tail coverts white.

Total length, 20 in. ; tarsus, 1.5 in. ; culmen, $1 \cdot 15$ in.

Hab. : 2, 3, 4, 6, 7, 8, 9.

\section{SUb-FAMilx-ANaTine.}

Hind toe very narrowly lobed. Bill rather flat and lobed.

Gends-DENDROCYCNA.-Lower portion of tarsus in front without transverse scutellæ, but covered with small reticulate scales.j

750. D. arcuata, Cuvier (Dendrocygna vagans, Eyton), Whistling Duck. Throat almost white; back and scapularies black, with the edges bright rufous-chestnut; breast pale rufous, each feather with black dots in middle; lower abdomen and under tail coverts whitish-buff, the latter uniform, but the abdomen with brown spots; the flank feathers with broad buffy-white streaks, edged with black; lesser and median wing coverts bright chestnut, greater ones and quills black.

$$
\text { Hab. : } 1,2,3,4,6,7,8 \text {. }
$$


750A. D. eytoni, Gld., Plumed Whistling Duck.

Head and neck light reddish-brown ; upper surface brownish-grey ; tertiaries reddish-brown, barred with black; flank feathers yellow, with darker margins.

Hab. : 1, 2, 3, 6, 7, 9.

GENUS-TADORNA.-Lower portion of tarsus in front with a row of transverse scutellæ. Bill broader towards tip than at base ; culmen rather concave; lamellæ more developed towards tip of upper mandible; lower mandible with the lamellæ not projecting out. wardly. Sexes similar.

751. T. radjah, Garnot, White-headed Shelduck.

Head and neck entirely white ; chestnut band across white chest; no knob at base of bill; tail black ; sexes similar.

Total length, about 19 in.; wing, 11 in.; tail, 5 in.; culmen, $1 \cdot 75$ in. ; tarsus, $2 \cdot 12$ in.

Hab. : 1, 2, 3, 8.

GENUS-CASARCA.-Lamellæ on edge of lower mandible projecting outwards.

752. C. tadernoides, Jardine, Shelduck or Mountain Duck.

Upper tail coverts black; breast rufous; white band above the chest. Male with the head and upper part of neck black, with a green gloss. Female, head brown, and a white band of feathers round the base of the bill.

Hab. : 4, 5, 6, 9.

GENUS-ANAS.-Bill broad, about as long as head.

753. A. superciliosa, Gmelin, Black Duck.

A very distinct black band through the eyes; sides of head and neck not rufous; general plumage distinctly mottled; speculum metallic-green; no white band anteriorly to the speculum.

Hab. : 1 to 9 .

Genus-NETTION.-Bill not very broad, more or less compressed, and shorter than head.

754. N. castaneum, Eyton (Anas castanea), Teal.

Upper wing coverts clay-grey or slate-grey.

Male.-Head and upper part of the neck dark metallic-green.

Female.-Cheeks dull greyish, finely streaked with black; no ring of white feathers round the eyes; usually no white edge on the outer web of the first primary.

Total length, male about 18.5 in., female 16 in.

Hab. : $2,3,4,5,8,9$.

755. N. gibberifrons, S. Müll. (Anas gibberifrons), Grey Teal.

"This species is absolutely similar to the supposed female of $\mathrm{N}$. castaneum both in colour and dimensions, so that I am utterly unable to distinguish it."-Salvadori.

Refer to Vict. Nat., vol. vii., 4.

Total length of male is 2 in. greater than the male of N. castaneum. Hab. : 1, 3, 4, 6, 7 .

Gends-SPATULA.-Bill spatulate; no soft membrane on sides of the bill towards its tip.

756. S. clypeata, Linn., European Shoveller.

Male.-Head and upper part of neck deep glossy green; abdomen deep chestnut.

Hab. : (4, N.S.W.) 
757. S. rhynchotis, Lath., Shoveller (Blue-wing).

Male.-Head and upper part of neck bluish lead colour, with a white crescentic band between the base of the bill and the eyes, extending to the throat; abdomen deep chestnut.

Female. - Head and neck buff; striated under surface mottled brown and buff.

Hab. : 3, 4, 5, 6, 9.

758. S. variegata, GId., New Zealand Shoveller.

Dark crescentic markings on white ground of neck, breast, and scapulars.

Visitor. One specimen recorded (North). Hab. : 5.

Genus-MALACORHYNCHUS.-Bill spatulate and has soft membrane on sides towards the tip.

759. M. membranaceus, Lath., Pink-eared Duck.

An oblong mark of rose-pink behind the eye; axillaries white; neck, breast, and under parts greyish-white, crossed by numerous brown bars, narrow on the neck, broader on the breast and flanks, and nearly obsolete on abdomen.

Hab. : 2, 3, 4, 5, 6, 7, 8, 9 .

Gexus-STICTONETTA. - Speculum wanting. Bill broader towards tip than at base, longer than head ; at the base much higher than broad; concave, and with the nail bent backwards as in Erismatura.

760. S. naevosa, Gld., Freckled Duck.

Whole of plumage dark brown and white; under surface with specks of lighter shade; primaries plain wood-brown.

Hab. : 3, 4, 6, 7, 9 .

\section{Sub-FaMily-Fuliguline.}

Hind toe broadly lobed. Tail feathers not particularly stiff.

Genos-NYROCA.-Bill smooth, not gibbous, at the base.

761. N. australis, Gld., White-eyed Duck (Widgeon or Hard-head).

Uniform reddish-brown, a band of lighter colour across breast; secondaries white at base, making a conspicuous mark on wing; iris white.

$$
\text { Hab. : 2, 3, 4, 5, 6, 7, } 9 .
$$

\section{SUB-Family-Erismaturine.}

Hind toe broadly lobed. Tail feathers narrow and very stiff.

Genos-ERISMATURA.-Tail eighteen feathers.

762. E. australis, Gld., Blue-billed Duck.

Male.-Breast, and usually the back and flanks, bright chestnut (adult male); chin, like the head, black; chestnut colour of the breast, flanks, and upper parts deeper.

Female.-Uniform brownish, with lines and freckles of chestnutbrown.

$$
\text { Hab. : 4, 5, 6, } 9 .
$$

Genos-BIZIURA.-Bill shorter than the head, very high at base. A pendent lobe on the chin. Tail feathers twenty-four.

763. B. lobata, Shaw, Musk Duck.

Large lobe beneath the chin, smaller in female.

Male. -Total length, 26 in. ; wing, 9.25 in. ; culmen, 1.7 in.

Female. - Total length, about 23 in.; wing, 7.5 in.; culmen, $1 \cdot 4$ in. Hab. : 3, 4, 5, 6, 7, 9 . 


\section{SUB-CLASS II.-RATITA}

(Sternum Without A Keel).

\section{ORDER-CASUARII.}

Hallux absent. Middle phalanges shortened. Maxillo-palatines large, fused with vomer and premaxilla.

\section{FAMIIYYDROM EID A.}

No casque on the head. Bill broad.

GENUS-DROM EUS.-Tarsi have reticulated scutes in front, except near the toes, and behind rough scales.

761. D. novae-hollandiae, Lath., Emu.

Feathers of body uniform greyish, with tips black; feathers of the neck greyish, with the tips black.

Total length, 78 in.

Hab.: 2, 3, 6, 7, 9.

765. D. irroratus, Bartl., Spotted Emu.

More slender than $\mathrm{D}$. novæ-hollandiæ.

Feathers of body barred alternately with silky-white and darkish grey throughout their length, terminating in a black tip, margined posteriorly with rufous.

Hab. : 7, 8, 9.

766: D. ater, Vieill. (Considered to be extinct.)

Feathers of the body uniform greyish, with the tips black; feathers of neck entirely black.

Total length, about 55 in.

Hab.: Kangaroo Island, S.A.

\section{FAMILY-CASUARIID $Æ$.}

A casque on the head. Bill narrow.

Genus-CASUARIUS. - Tarsi have large hexagonal scutes, except near the toes, where the scutes are transverse.

767. C. australis, Wall, Cassowary.

Casque compressed on the sides ; only two wattles on the throat, not far apart, but approached one to the other; the casque very high and thinner above; nail of the inner toe longer than galeatus, and bird larger; wattles very large.

Hab. : 2. 


\section{INDEX TO GENERA.}

\begin{tabular}{|c|c|c|c|c|c|}
\hline & PAGE & & PAGE & & PAGE \\
\hline Acanthiza & 24,25 & Calamoherpe - & - 20 & Cymodroma & 92 \\
\hline canthochær & 44,45 & Calidris - & & Cypselus & \\
\hline canthorhyn & chus - & Callocalia & - 54 & & \\
\hline canthornis & - 26 & Callocephalon & - 62 & Dacelo & - 57 \\
\hline ccipiter & - & Calopsittacus & - 63 & ion - & \\
\hline crocephalus & - 20 & Calornis & $-\quad 48$ & gretta & - 99 \\
\hline & -85 & Calyptorhynchu & 61,62 & ocycna & -106 \\
\hline Egi & 82,83 & Campephaga - & - 12 & Dicæum & -46 \\
\hline Agi & -51 & lgus - & - 54 & dea & 95,96 \\
\hline les & - 55 & Car & - 97 & Dc & -50 \\
\hline Aelurœedus & -21 & aga - & -70 & Dr & -109 \\
\hline yne & -50 & $\mathrm{Ca}$ & -107 & ıœdus & 28 \\
\hline & -56 & Cas & -109 & $\mathrm{Du}$ & -100 \\
\hline a & - 49 & ctes. & -104 & & \\
\hline nis & 77 & Cat & & soma & 2 \\
\hline - & 23 & Cer & - 60 & El: & 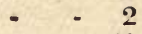 \\
\hline & -107 & Cer & & $\mathrm{Er}$ & - 49 \\
\hline ochilus & -86 & $\mathrm{Ce}$ & -106 & phila & - 40 \\
\hline . & 89,90 & Che & - 54 & En & \\
\hline nas & -105 & ecyx & -59 & Eo & 32,33 \\
\hline - & -47 & aps - & - 71 & aura & - 30 \\
\hline ne & -78 & $\mathrm{Ch}$ & - 81 & Er & -108 \\
\hline hictus & -64 & & -106 & rogonys & -80 \\
\hline a. & 1 & $\mathrm{Cl}$ & -105 & is - & \\
\hline & -98 & eca & - 47 & Es & \\
\hline ta. & -100 & $\mathrm{Ch}$ & -10 & nis & -59 \\
\hline ria & - 80 & ydodera & - 22 & & -105 \\
\hline & - 19 & $\mathrm{Ch}$ & & nis & \\
\hline ius & - 48 & phus & & & 67,68 \\
\hline & $-4,5$ & $\mathrm{ma}$ & 27,28 & $\mathrm{E}$ & 78 \\
\hline - & 6 & C & 36 & & 55 \\
\hline & - 52 & $\mathrm{Ci}$ & & & -56 \\
\hline & -103 & hynchus & $\begin{array}{l}-\quad 24 \\
-\quad 83\end{array}$ & ctoria & \\
\hline & 66 & Cli & & & \\
\hline & 85 & cincla & & culus & \\
\hline Bathilda & - 51 & Col & 70 & a - & -103 \\
\hline & - & $\mathrm{Co}$ & & & \\
\hline & -108 & $\mathrm{Co}$ & & Fulınaris & - 93 \\
\hline & -100 & & 7 & & \\
\hline & & Co & & & 90 \\
\hline \multirow[t]{2}{*}{ Butorides } & 99 , & $\mathrm{Cr}$ & 31,32 & Ga & \\
\hline & & Craspedop? & & & 77,78 \\
\hline & & & & & - \\
\hline & & $\mathrm{Cuc}$ & 58 & Ga & - \\
\hline & 29,30 & Cyclopsittacus & & Gelochelid & \\
\hline
\end{tabular}




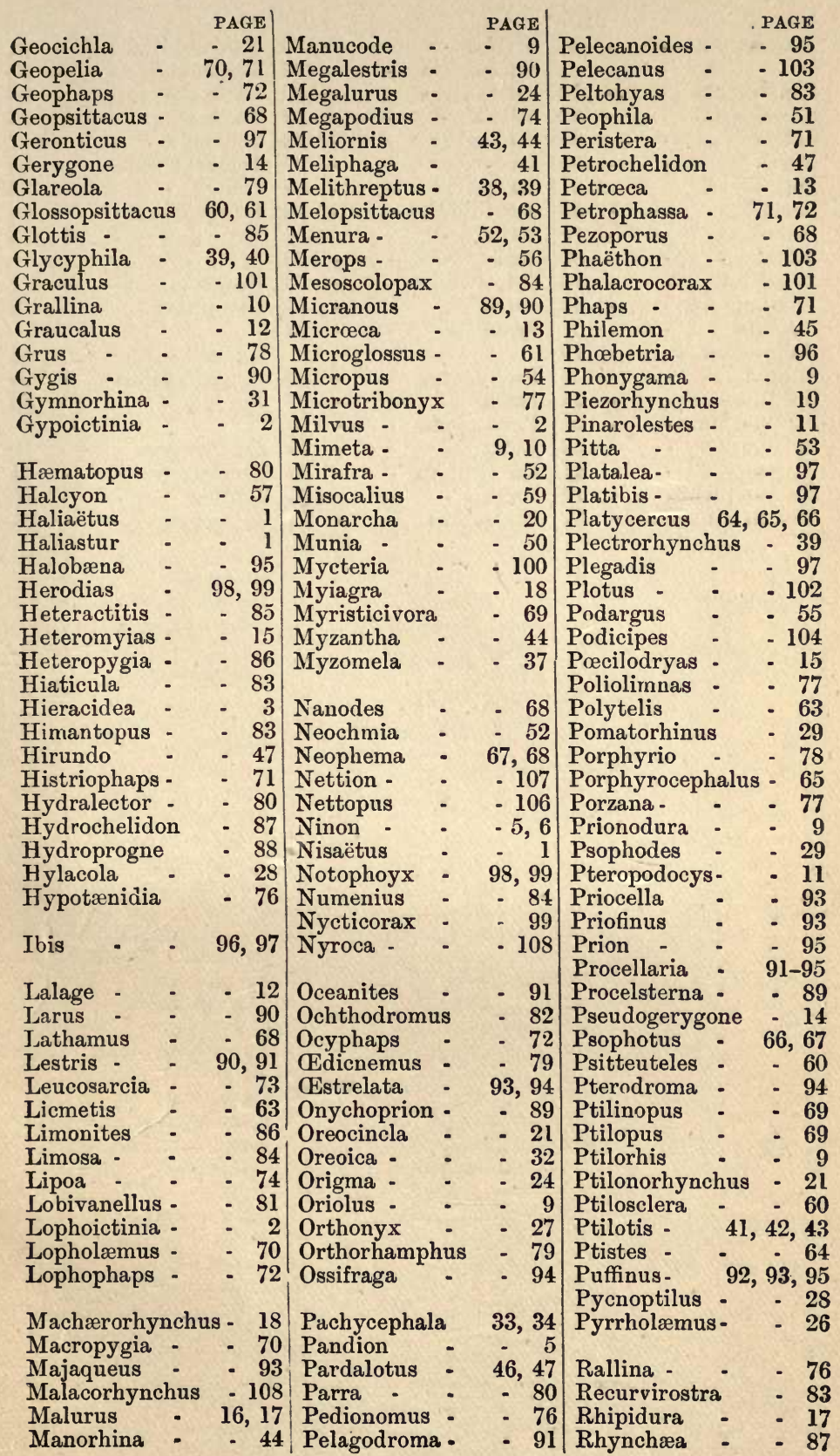




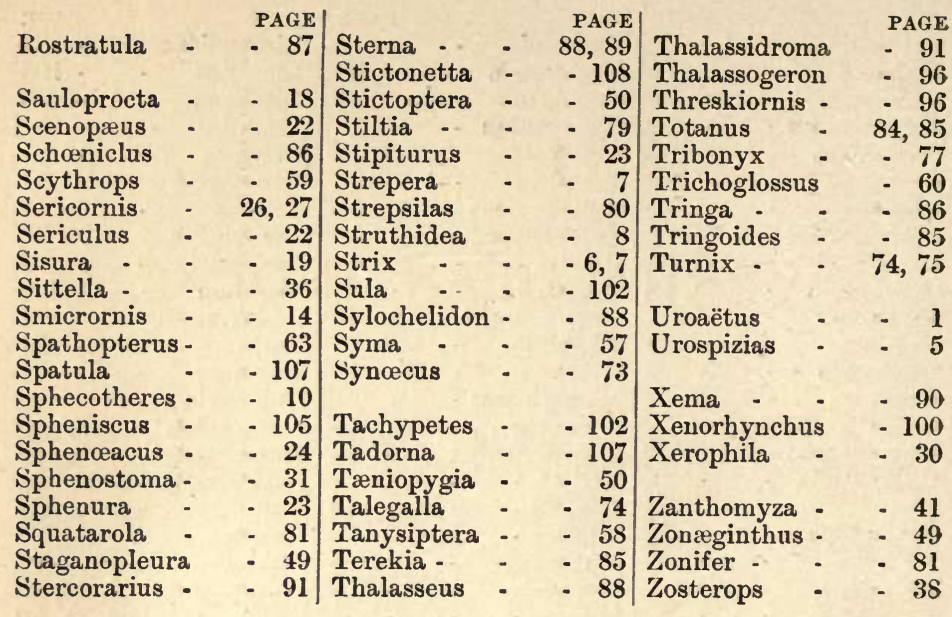




\section{VERNACULAR INDEX.}

\begin{tabular}{|c|c|c|c|c|c|}
\hline & $\begin{array}{r}\text { PAGE } \\
24,25\end{array}$ & ottrel & $\begin{array}{r}\text { PAGE } \\
808283\end{array}$ & Kingfisher & $\begin{array}{r}\text { PAGE } \\
56-58\end{array}$ \\
\hline & 95,96 & Drongo - & $00,02,00$ & Knot & $\begin{array}{l}-86 \\
-\quad 86\end{array}$ \\
\hline & -52 & Duck & $-106-108$ & Koel & - 59 \\
\hline & - 83 & & & & \\
\hline & & Eagle & $-1,2$ & alage & 12,1 \\
\hline & $\begin{array}{l}-29 \\
-\quad 78\end{array}$ & et & 98, 99 & hing & cka \\
\hline & -56 & Emu & & unn & $\begin{array}{l}27 \\
-\quad 27\end{array}$ \\
\hline 1. & - 99,100 & Falcon & & & 52 , \\
\hline (Gann & - 102 & ail 13,1 & $7,18,19,20$ & & \\
\hline $\begin{array}{c}\text { 3ower-bird } \\
, \quad \text { (Pri }\end{array}$ & $\begin{array}{r}21,22 \\
\text { ionodura) } 9\end{array}$ & Wren & $24,29,30$ & $\begin{array}{l}\text { Magpie } \\
\text { Magpie Lark }\end{array}$ & $\begin{array}{l}-\quad 31 \\
-\quad 10\end{array}$ \\
\hline ristle-bird & $-\quad-23$ & & 49 & Fowl & $\begin{array}{r}-74 \\
-74\end{array}$ \\
\hline & - 78 & $\mathrm{ch}$ & $13,(17-20)$ & Manucode & - \\
\hline ird & 31,32 & $\mathrm{Fly}$ & 14,15 & $\mathrm{Ma}$ & -47 \\
\hline & - 2 & te-bird & - 102,103 & Meg & $\begin{array}{l}-74 \\
-\quad 46\end{array}$ \\
\hline 8 & 29,30 & Fro & - 55 & hen & 77 , \\
\hline 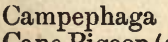 & 12,13 & Gal & & & \\
\hline igeor & see Petrels) & Ga & $\begin{array}{r}1,102 \\
-102\end{array}$ & $m p$ & \\
\hline ry & $\begin{array}{r}109 \\
-\quad 21\end{array}$ & & 105,106 & & \\
\hline lar-ea & ater 12,13 & one & 14,15 & & \\
\hline 1-bill & -59 & & $\begin{array}{l}-84 \\
-\quad 24\end{array}$ & a - & - \\
\hline - & - 30 & & $-\quad 24$ & 0 & 9,10 \\
\hline $\operatorname{rer}(\mathrm{Ba}$ & abbler) 29 & Wren & $\begin{array}{l}-\quad 24 \\
-\quad 23\end{array}$ & onyx & $-\quad 27$ \\
\hline & 8 & $\begin{array}{l}\text { Wren } \\
\text { alus }\end{array}$ & $\begin{array}{r}20 \\
-\quad 12\end{array}$ & 0 & $\therefore$ \\
\hline & $\begin{array}{r}29 \\
-61-63\end{array}$ & Gr & . 104 & -cat & \\
\hline & $\begin{array}{r}-78 \\
-\quad 1\end{array}$ & Greenshank & 84,85 & & 46 \\
\hline rant & .101 & & & & - \\
\hline icola & - 24 & & - & $t$ tribe & 60 \\
\hline & - 60 & & & & - \\
\hline & 76,77 & $G$ & & din & \\
\hline$\because$ & $\begin{array}{l}-\quad 78 \\
\end{array}$ & & & 1 . & \\
\hline - & $\begin{array}{r}98,99 \\
-\quad 7\end{array}$ & $1 \mathbf{H}$ & $\begin{array}{r}-1-5 \\
98,99\end{array}$ & n - & \\
\hline aril & $-7,8$ & y-eater & $37-45$ & . & -47 \\
\hline & $58-60$ & Hylacola & - 28 & Pit & -53 \\
\hline -Sh & 11,12 & & & er . & 79,81 \\
\hline Curlew (Land & - 79 & Ibis & 96,97 & rgus & -5 \\
\hline$"$ & & & & acole & - \\
\hline & -104 & & 80 & Prionodura & - \\
\hline & - 46 & Chor & & & \\
\hline & - 56 & Jumper - & - & Quail & \\
\hline
\end{tabular}




\section{4}

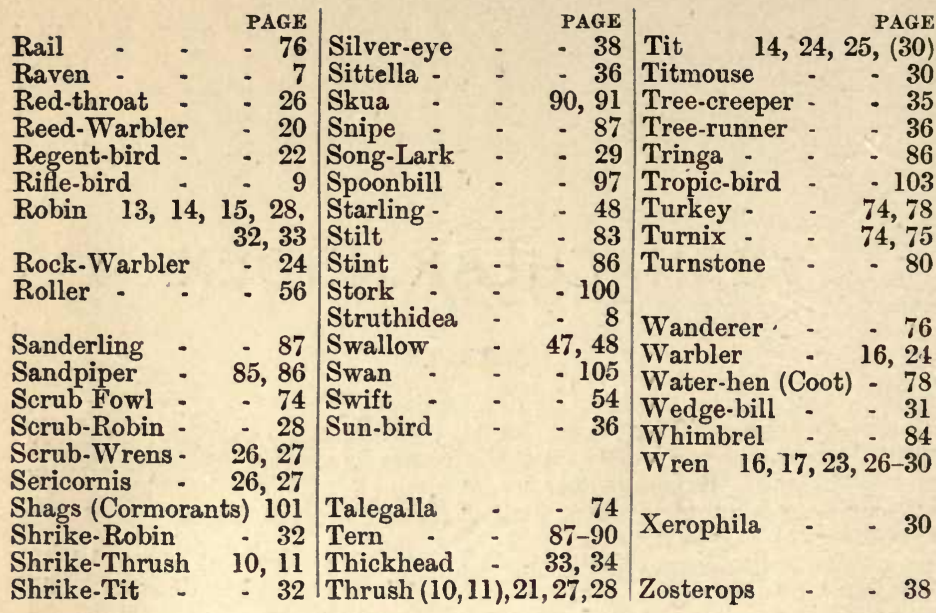




\section{GLOSSARY.}

Agrthognathous.-The skull having the maxillo-palatine processes separated by a cleft, and the vomer truncated in front, narrow behind. Examples, perching birds.

AFTER ShaFt. - Supplementary shaft of feather (long in Emu).

ANISODACTYL. - Unequal toed.

AURICULAR. - Pertaining to the ear.

AxILLA.-Arm-pit.

BASTARD WING.-Group of short, stiff feathers growing on pollex or thumb.

BIFID. - Two cleft.

CACUM. - Part of intestine.

Callosity.-Hardened part.

CASQUE. - Helmet.

CERE.-Membrane at base of upper mandible.

CNemial.-Pertaining to the tibia.

Commissure.-Corner of mouth; frequently applied to whole line of closure of the bill.

Contodr Feathers. - Body feathers.

Coriaceous. - Leathery.

Corvine.-Crow-like.

Culmen.-Highest middle lengthwise line of upper mandible.

CULminicorn.-Horny covering to culmen.

Cuneate. - Wedge shape.

Cutaneous. - Skin-like.

Dertrum.-Swollen tip of bill.

Desmognathous. - The skull having the maxillo-palatine processes united to form a bony roof to the palate; the vomer truncated in front, small or obsolete. Example, duck.

EMARginated. - Notched.

EPIGNathous.-Hook-billed.

FEMUR. - Bone above tibio-tarsus.

Fossa.-Groove.

Furcate.-Forked.

Furcula.- "Wishing bone" of breast.

GAPE. - Line of commissure of mandible.

GibBous.-Swollen.

GoNys (Genys).- Under middle line of lower mandible from junction of prongs to tip.

Goraet. - Metallic throat-plate.

GuLAR. - Pertaining to region of middle throat.

HaLluX.-Hind toe.

HolorhiNaL. - Nasal bone unsplit.

INTERRAMAL. - In fork of lower jaw.

INTERSCAPULUM. - Between shoulders.

LAMELLE. - Thin plates.

LANCEOLATE. - Tapering.

LATERICORN. - Horny side plate of bill. 


\section{6}

LORE.-Space between eye and base of upper mandible.

MALAR.-Pertaining to cheek.

Mandibles. - Upper and lower jaws with their covering.

MANUBRIUM.-Process of the fore-border of sternum.

MAXILla.-Lateral margin of upper mandible.

NAPE. - Upper part of neck behind.

NUCHAL.-Pertaining to region of neck.

OccIPUT. - Hind-head.

OCREate. - Having the tarsal envelope continuous ; booted.

OperCULUM. - A lid.

OrBITAL. - Region of eye.

Oscinks. - Singers.

Pectoral. - Breast region.

Pervious. - Open.

Phalanges. - Bones of digits of hand and foot.

Pileum. - Whole top of head.

Planta.-Sides and back of tarsus.

Plumules.-Down feathers.

Primaries.-Main flight feathers growing on pinion or hand.

RECTRICES. - Tail quills.

REMIGES. - Quills of wing.

RICTAL.-Pertaining to gape.

ROSTRuM.-Bill.

ScAPUlaries. - Feathers on the shoulder-blades.

Schizograthous. - The skull having maxillo-palatine processes of the maxilla separated by a cleft, and the vomer long and pointed in front, narrow behind. Example, common fowl.

Schizorhinal. - Split nasal bone.

Scutellate.-Having small plate-like surfaces.

SECondaries.-Flight feathers seated on the fore-arm (ulna).

SEMI-PALMATED. - Half-webbed.

ShAFT. - Main stem of feather.

Spatulate. - Spoon-shaped.

SPECUldm.-Conspicuous bright spot.

SPURIOUS WiNG.-Bastard wing.

STERNDM. - Breastbone.

Subclate.-Awl-shaped.

Solcus.-Furrow.

SYNDACTYL.-Joined toes in part of length.

TARsus.-Lower part of leg.

TERTIALs.-Innermost secondaries growing upon humerus.

TнuмB.-Pollex or outer digit of hand.

Trbio-tarsus. - Middle long bone of leg.

TомrсM.-Cutting edge of bill.

VOMER. - A membrane bone of the skull in the median line; sometimes in paired halves, one on each side of the median line.

ZYGODACTYL. - Toes arranged in pairs, two in front and two behind. 



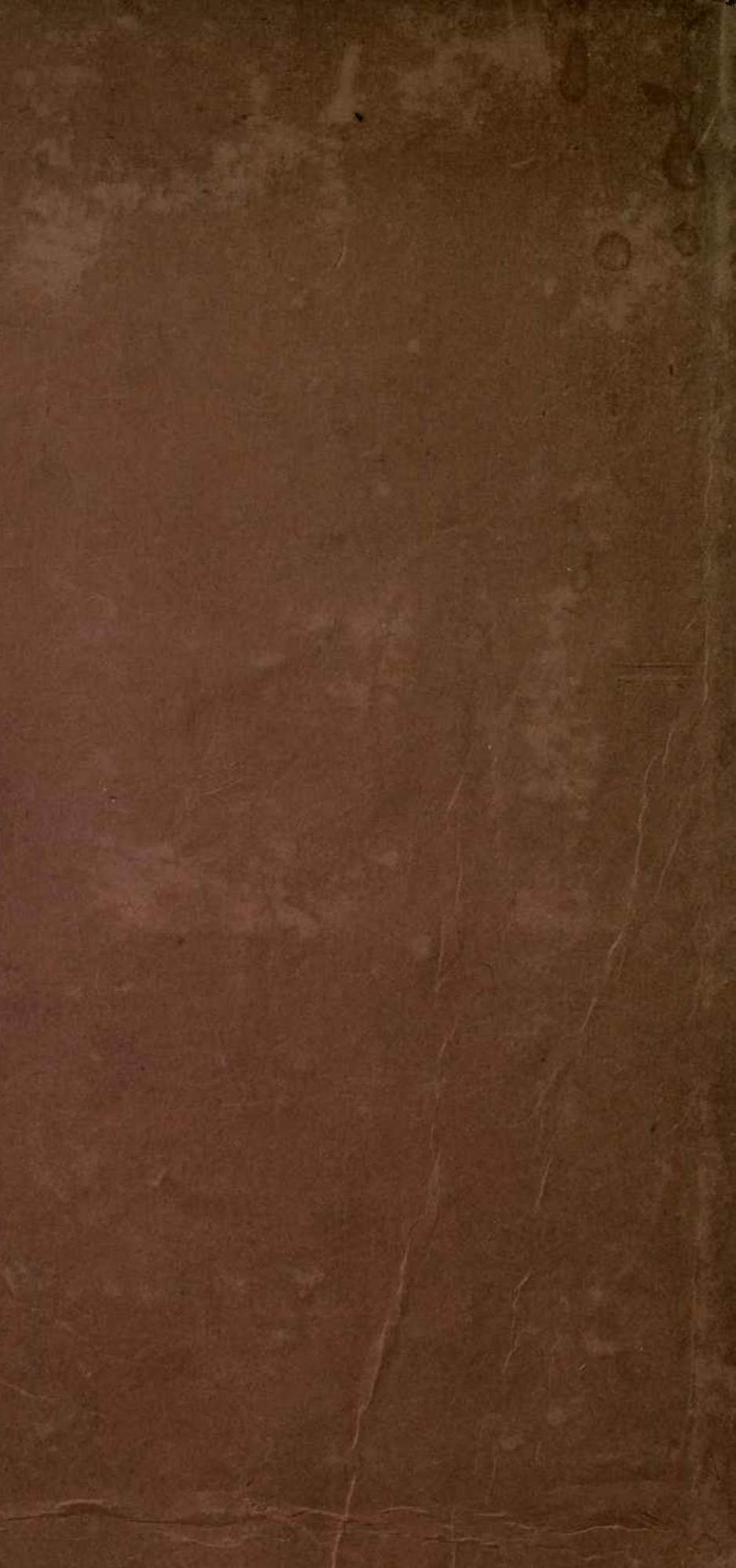

